U.S.Army

Coast.Eng. Res. Ctr.

MP 4-74

\title{
Hydraulic Method Used for Moving Sand at Hyperion Beach Erosion Project, \\ El Segundo, California
}

MISCELLANEOUS PAPER No. 4-74

\section{JUNE 1974}
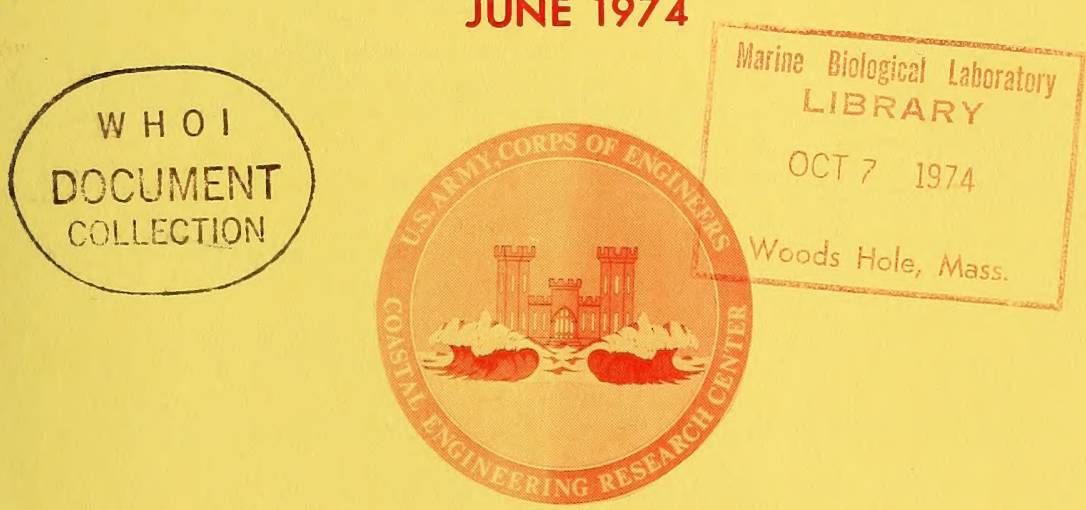

Approved for public release;

distribution unlimited

$G B$

450

.43

no. $4 \cdot 74$

\section{U.S. ARMY, CORPS OF ENGINEERS \\ COASTAL ENGINEERING \\ RESEARCH CENTER}

Kingman Building

Fort Belvoir, Va. 22060 
Reprint or republication of any of this material shall give appropriate credit to the U.S. Army Coastal Engineering Research Center.

Limited free distribution within the United States of single copies of this publication has been made by this Center. Additional copies are available from:

\section{National Technical Information Service ATTN: Operations Division 5285 Port Royal Road \\ Springfield, Virginia 22151}

Contents of this report are not to be used for advertising, publication, or promotional purposes. Citation of trade names does not constitute an official endorsement or approval of the use of such commercial products.

The findings in this report are not to be construed as an official Department of the Army position unless so designated by other authorized documents. 


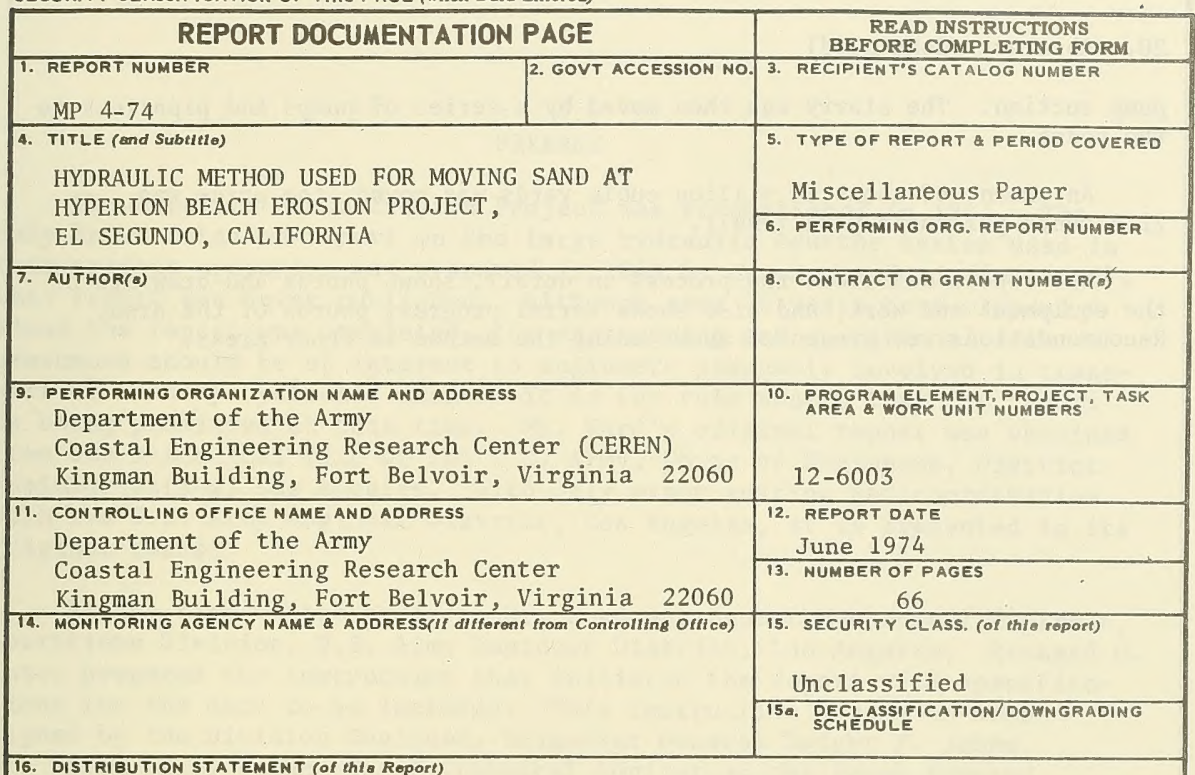

Approved for public release; distribution unlimited.

17. DISTRIBUTION STATEMENT (of the abstract entered in Block 20, if different from Report)

18. SUPPLEMENTARY NOTES

19. KEY WORDS (Continue on reverse alde if necessary and Identlly by block number)

E1 Segundo

Hyperion Beach

Beach fill

Beach erosion
Sandhills

Hydrau1ic method

20. ABSTRACT (Continue an reverse alde $1 /$ neceseary and identify by block number)

This report describes a project at Los Angeles in 1947. Sandhills (relic dunes) were leveled, and the sand was used to widen the beach against erosimn. The project extended from E1 Segundo to Venice.

Water, at high pressure, was shot from nozzles onto the hills. The resulting slurry (sand suspended in water) was sluiced down to a sump or low area. An eductor drew in the slurry by siphon, and discharged it by pipeline to a surge pit. Here, the slurry moved through a surge well to a dredge 


\section{Abstract (Continued)}

pump suction. The slurry was then moved by a series of pumps and pipelines to the beach.

An amount of about 14 million cubic yards was moved; the price was 22.6 cents per cubic yard (1947).

The report describes the process in detail, shows photos and drawings of the equipment and work, and also shows aerial progress photos of the area.

Recommendations are presented about using the method in other areas. 


\section{PREFACE}

The Hyperion Beach Erosion Project was accomplished in 1947. The only known detailed report on the large hydraulic eductor system used in this project operation was prepared in 1948 by Mr. James Hurd (deceased). This report was never published. Although some 26 years have elapsed since the report was completed, the engineering and operational data presented should be of interest to engineers presently involved in transport of sand by hydraulic means. It is for this reason that the report is being published at this time. Mr. Hurd's original report was obtained from the historical file of the U.S. Army, Corps of Engineers, District Engineer Office, Los Angeles. With only minor editing and coordination with the U.S. Army Engineer District, Los Angeles, it is presented in its original format.

At the time of the project, Mr. Hurd was Senior Mechanical Engineer, Operations Division, U.S. Army Engineer District, Los Angeles. Richard 0. Eaton prepared the instruction that initiated the report with specifications for the data to be included. This instruction became an order signed by the Division Engineer, Brigadier General Dwight F. Johns. Mr. Eaton later became Chief Technical Advisor at the Beach Erosion Board and the Coastal Engineering Research Center, serving from 1951 to 1963.

The Project was proposed by the Los Angeles City Engineer, the beach fill features were conceived by Arvid Johnson (deceased) of the City Engineers Staff. Credit then should be given to Arvid Johnson, James Hurd, Richard Eaton, and to the Construction Aggregates Corporation for their fine engineering effort in solving a unique earthmoving problem.

NOTE: Comments on this publication are invited.

Approved for publication in accordance with Public Law 166, 79th

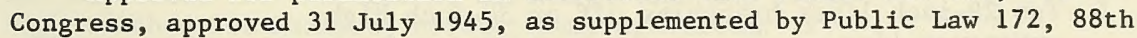
Congress, approved 7 November 1963.

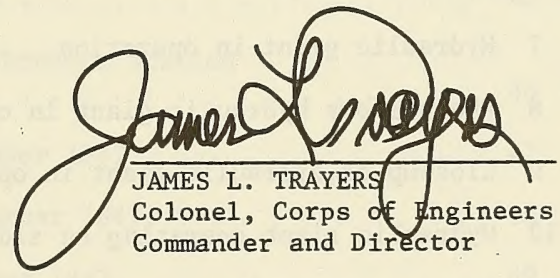


I GENERAL DESCRIPTION .................. 5

II PLANT OPERATION AND DATA . . . . . . . . . . 11

III CONCLUSIONS ........................ 15

\section{TABLES}

1 Hyperion Excavation - Survey Interval (Monthly Hydraulic Quantities) .............. 12

2 E1 Segundo Pumping P1ant - Operational Data . . . . . 16

3 Average of Readings .............. 17

\section{FIGURES}

1 Photo of main pumphouse, with some appurtenant equipment . . 20

2 Switchboard in main pumphouse............. 21

3 Water pumps No. 1 and 2 with blowers for motors shown at left.................. 22

4 Photo showing 36 -inch discharge line from pump No. 2 to general vicinity of operations............ 23

5 Photo of 36-inch line from pump No. 2, showing takeoff point where 28- and 21-inch lines branch off. . . . . . 24

6 Two 28-inch 1 ines branching off of 36-inch highpressure line............... 25

7 Hydraulic giant in operation . . . . . . . . . 26

8 Photo shows hydraulic giant in operation . . . . . . . 27

9 Closeup of hydraulic giant in operation. . . . . . . 28

10 Hydraulic giant operating on side of embankment. . . . . . 29

11 North section of surge pit . . . . . . . . . . 30

12 North section of surge pit . . . . . . . . . . 31 


\section{CONTENTS - Continued}

FIGURES

Page

13 South section of surge pit and surge wel1. . . . . . . . . 32

14 Photo shows pumps No. 3 and 4 in the main pumphouse..... . 33

15 Booster pumping station with cooling tower, transformers and plant operating equipment . . . . . . . . . . 34

16 Booster pumping station and pumps No. 5 and $6 . . . . . . .35$

17 Photo shows discharge of material at deposit area. . . . . . 36

18 Two 36 -inch sea lines leading to the main pumphouse (foreground); surge pit in center of photo. . . . . . . . 37

19 Northern operating area, 2 May 1947. . . . . . . . . . 38

20 Central area of operation, 31 May 1947 . . . . . . . . . . 39

21 Photo shows depositing of material both by sluicing and pumping................ . . . 40

22 Northern area of operation, 31 May 1947. . . . . . . . . 41

23 Photo (31 May 1947) shows pipeline extending farther down the beach. ......................... 42

24 Central operating area, 7 July 1947. . . . . . . . . . . 43

25 Northern operating area, $7 \mathrm{July} 1947$. . . . . . . . . . 44

26 On 7 July 1947, length of discharge line has about reached its maximum; booster pumping station is being prepared for installation ........... . . 45

27 Photo taken 8 August 1947 shows booster station being installed............... . . . 46

28 Central operating base, 4 September 1947 . . . . . . . . 47

29 Northern operating area, 4 September 1947. . . . . . . . . 48

30 Southern operating area, 7 October 1947. . . . . . . . . 49

31 Northern operating area, 7 October 1947. . . . . . . . . 50 


\section{CONTENTS - Continued}

FIGURES

Page

32 Central and northern areas, 10 November 1947 . . . . . 51

33 Photo taken 10 November 1947 shows installation of booster station and pipeline extending some 1,000 yards northward. . . . . . . . . . . . 52

34 Southern area, 10 November ............. 53

35 Northern and central areas, 1 December 1947. . . . . . . 54

36 Central and northern areas of operation, 1 December 1947 . . 55

37 Photo taken 1 December 1947 shows buildup of beach to the north ................ 56

38 View of cqmplete area of sand removal, 13 January 1948 . . . 57

39 Photo taken 13 January 1948 shows beach area deposited in northerly direction, and other sections added to discharge line.............. 58

40 Details of surge well, sand eductor and sluice pipe. . . . 59

41 Data on Hendy Hydraulic Giants . . . . . . . . . . . 60

42 General arrangement of pumps, giants, eductors, surge

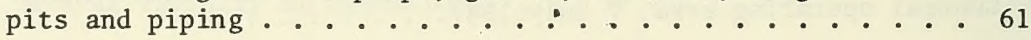

43 Details of 28 -inch pump casing . . . . . . . . 62

44 Details of cast steel impeller . . . . . . . . . 63

45 Details of sand eductor assembly . . . . . . . . . 64

46 Details of she11 liner assembly, 28-inch sand pump ..... 65

47 Eductor operating arrangement (giant and pump impeller details) 


\author{
HYDRAULIC METHOD USED FOR MOVING SAND \\ AT HYPERION BEACH EROSION PROJECT, EL SEGUNDO, CALIFORNIA
}

\title{
I. GENERAL DESCRIPTION
}

Peter Kiewit Sons \& Company and Construction Aggregates Corporation, Joint Contractors and Coadventurers, had the contract from the city of Los Angeles for repairing the beach erosion from El Segundo to the Venice Pier.

The earth and sand material for filling were obtained from the sandhills (relic dunes) along the beach near the Hyperion Sewage Disposal Plant. The hydraulic method for moving material has been employed. The system as used was developed by Mr. Sensibar of Construction Aggregates. Certain details of the system have been forwarded to the United States Patent office for patenting; other phases have been in use for a considerable number of years.

A general discussion of the Sensibar method of moving the material suspended in water through pipelines from one point to another follows:

Water under pressure is forced through a nozzle onto the sandhills from which the material is to be obtained. The sand suspended in water is sluiced down to a sump or low area where a sand eductor is located. The eductor draws in the slurry (sand suspended in water) by siphon action, and discharges it into a pipeline extending to a surge pit and thence through the surge well to the dredge pump suction. The water-sand mixture is then drawn into a pump and discharged through a series of pumps and pipelines to the area into which the material is to be deposited for filling.

A description of the actual operation at the E1 Segundo-Hyperion plant follows:

About 300 feet from the shoreline, a pump station was built. Four 28-inch dredge pumps are located in this area with all necessary equipment for operation and maintenance. Two 36-inch pipelines 800 feet long forming a "Y" at the pumphouse, are sea-suction lines and extend out into the ocean parallel to each other and about 50 feet apart, for a distance of about 500 feet beyond the shorcline and 6 feet below the centerline of pump No. 1. From the "Y" connection, a single 36-inch line connects to pump No. 1, which draws in seawater at from 15 to 20 inches of vacuum. The water is discharged at a pressure ranging up to 80 pounds per square inch into a 30-inch line which is enlarged to a 36-inch intake line for pump No. 2 located in the same pumphouse at right angles to pump No. 1 and at an elevation about 9 feet above pump No. 1 from center of the discharge on pump No. 1 to the center of intake on pump No. 2. Pump No. 2 increases the pressure of water from 80 to about 160 pounds per square inch, and discharges into a 36-inch main-pressure line which runs parallel to the intake line, about 300 feet long, and extends toward locations in which 
high-pressure water is required. From the 36-inch main-pressure line, water is distributed to the surge we11, hydraulic giants, eductors and to the water-cooling system for the auxiliary equipment used with the pumping activities. Branching off from the 36-inch main are two 28-inch lines through which water is carried nearer to the sand-moving operation. Branching off from the 28-inch lines are two 21-inch lines at each operational point, one as a pressure line to the hydraulic giant and one as a pressure line to the sand eductor. To eliminate as much pipeline friction as possible, the lines are as large in diameter as can be satisfactorily handled in laying or moving from place to place.

At each point of operation, which is usually from 75 to 200 feet from the sandhill which is to be moved, are located the hydraulic giant and eductor. The hydraulic giant ejects the water at high velocity and at a pressure varying between 60 and 120 pounds per square inch onto the sandhi11. The water dislodges the sand, and the suspended sand in water flows downgrade, a distance of from 75 to $200 \mathrm{feet}$, on a slope which creates enough turbulence to hold the sand material in suspension. At the base of this slope is the eductor, which picks up the sand-water mixture and starts its flow through a venturi and thence into a 21 -inch or 28-inch line which flows into the surge pit. A high-pressure water line also enters into the eductor, and water is ejected through a nozzle at 65 to 125 pounds per square inch pressure, directly into the venturi and acts, in a measure, as a force to carry the suspended material through the pipe. The venturi thus creates a suction, also helping to carry additional material through the discharge pipe. In most operational cases, the discharge line has a negative slope, or a drop of from 0 to 4 percent; however, in some cases the line has had a positive slope of 5 percent. The suspended material in the various discharge lines flows distances up to 2,600 feet to reach the surge pit. All of these discharge lines enter the surge pit, which is located on the slope directly in back and above pump No. 3 in the pumphouse.

The material in the surge pit flows into the surge we11, which is a rectangular steel box, divided into three sections, with a trash rack surrounding it to prevent foreign material from entering the well. The suspended material flows into this well through slide gates and then, by gravity, down to the pumphouse via a 36-inch line to pump No. 3 . If the sand suspension is too heavy, additional water is added at the surge well by a pipe coming from the 36-inch high-pressure 1ine. Pump No. 3 draws in the water at from 4 inches of vacuum to 2 pounds per square inch pressure, and discharges the mixture into a 30 -inch line at about 80 pounds per square inch pressure. This line leads into pump No. 4, set at right angles to pump No. 3 and 9 feet above it. The material is discharged from pump No. 4 into a 28 -inch line at about 155 pounds per square inch pressure. This line extends about 11,200 feet along the beach on the same plane to a booster station which has two additional 28-inch dredge pumps. These pumps are so located that they can be operated individually or in series with each other, dependent upon the length of the discharge line to the point of depositing the material. At the booster station, the pressure in the 28-inch discharge line from pump No. 4 has decreased to from 2 to 
15 pounds per square inch. If the discharge line is so long that one pump cannot handle the material satisfactorily, it is discharged from pump No. 5 to pump No. 6 , which increases the pressure to 155 pounds per square inch. The pressure at the end of the line will vary with its length and the amount of solids in the suspension.

When the General Arrangement drawing was made (see Figures), there were 7,950 feet of 28-inch pipe between the booster station and the point of material deposit. One pump was satisfactorily handling all of the material. These pumps were alternating in operation each week, as it was necessary to rebuild a sand pump after one week's continuous operation. At a distance of about 50 feet from the booster station, a 12-inch line is connected into the 28 -inch discharge line. This line has a valve which can be opened at any time, and is used as a safety measure to relieve pressure in case of a breakdown in the pumphouse. Shut-off valves or plates are located before and after each pump in the system. These valves can be closed when making repairs to the pumps. Throughout the system, at each change in pipe dimensions, at each branch line, eductor or nozzle are located gate valves, to shut down any part of the line for repairs or change in directional flow. At one point on the water line and one point on the sand line is located a spring-loaded check relief valve, so that if a water hammer develops, the safety check valves will prevent a pipe fracture.

A 36-inch overflow line is connected to. the surge we11, and extends down to roughly the high tide water level. This line drains off any excess water, and, in case of breakdown, can be used to discharge material accumulating from the eductors and sluicing lines until they can be closed down.

The schematic general arrangement sketch (see Figures) will aid in following the system for moving sand and material through the various phases of operation. Other Figures indicate general construction and use of the component parts of the system.

To fully understand the plant operation, a breakdown of component assemblies is advisable. Component assemblies consist of: main powerplant; surge we11; hydraulic giants; eductors and sluices; and booster pump powerplant.

The main powerplant is a semipermanent installation. All machinery is mounted on concrete foundations and is enclosed by a sheet metal structure. Within the main pumphouse are four major pumps; two carrying seawater at high pressure to the central points of operation and two sand pumps discharging the suspended material at high pressure. The four main units are 28-inch centrifugal dredge-type pumps, direct-connected and driven by General Electric induction-type motors, 6600 volts, 202 amperes, 60 cyle, 253 revolutions per minute at full load and 2,500 horsepower. Pump No. 1 is a Fort Peck pump which has been modified by enlarging the impeller diameter from 77.5 inches to 88 inches, to increase its capacity. 
The other three major pumps in the pumphouse are a design of Meckum Engineering Co. of Chicago, Illinois and have an 88-inch impeller. The design of the Meckum pump differs from the conventional-type dredge pump in that the pump liners are made up of a number of subassemblies which can be removed and worn sections replaced. The impeller is also of a radical design in that it has only four impeller blades with a tip angle of 19 degrees, and has a capacity for handling 42,000 gallons per minute at approximately full load operation.

The pumps are located in the pumphouse to eliminate as many pipe bends and directional changes as possible. Auxiliary equipment includes three sump pumps for discharging leakage from various pumps, the surge we11, and ground moisture entering the pit. A large switchboard is located on the upper level of the pumphouse. This switchboard contains a11 necessary instruments, switches and controls for operation of the plant as well as indicators, meters and gauges for voltage, amperage, speed, kilowatts and pressures throughout the pumphouse system. Just outside the pumphouse is a bank of transformers for feeding current to the General Electric induction-type motors and other appurtenant facilities.

The surge well is located slightly above and behind the pumphouse in a large open pit. The well is a structural steel rectangular tank, 30 feet deep, 10 feet wide and 12 feet 8 inches long, divided into three sections consisting of the sand section, the water section and the overflow. The tank shel1 is made up of 0.875 -inch plate; its base rests on the bottom of the surge pit. To protect the we11, $2 \times 2$ angles surround the entrances on the water side. On the opposite two sides are shoulders of sand and piling, thus actually making two separate pits, one each side of the surge we11.

Operation of the surge well follows: sand in suspension being sluiced down into the surge pit or forced down by the eductor enters the pit and flows down to the surge well by gravity where it enters through slide gates. Three gates are located on each side of the surge well at different heights, and can be adjusted to allow for the flow that can be handled by the intake pump No. 3. When the sand in suspension drops to the base of the well it creates great turbulence, and is drawn into a 36-inch intake line to pump No. 3. If the suspended material is too thick for satisfactory handling by pump No. 3 , it can be thinned by two methods. One method is to open one or more valves on the four 4-inch lines which enter the surge well to a depth even with the first slide gate. This allows water from the high-pressure line to flow directly into the bottom of the surge we11, creating high turbulence and thinning the mixture. This operation is used mainly when a high level of sand and water is reached in the sand section and the turbulence is lost, thus allowing the sand to settle and pile up about the intake line. If the sand is settling in the surge pit around the sand gates, the Hendy Giants located at either end of the pit can be opened and water jetted into the sanded area, stirring it up and clearing the sanded gates, thus thinning the mixture. 
If the mixture is too thin, the second compartment, or water compartment, is brought into use. This compartment has a bottom which is 9.33 feet above the base of the surge well. It is divided into two sections, one serving each side of the surge pit and each having three flap-type water gates. When the height of the water in the pit reaches the water flap gates, they can be opened on the side of the pit where the water has accumulated. The water then runs down into the base of the water section and forces the flap gate to the discharge section open, thus draining the excess water into compartment No. 3 , and 36 -inch sea'line. This waste water is stopped from entering the other side of the water compartment by the flap gate in that section being held closed by the pressure exerted against the flap gate from water entering the discharge compartment.

The third section of the well is of the same dimension as the second section, and is only for discharging extra unused water to the sea. Two flap gates are located in the dividing wall between the water section and the waste section, and open out into the waste section. Each of the six gates are activated by hydraulic rams, one for each gate. The flap gates are operated by drum-type winches. The figure showing details of the surge we11, sand eductor and sluice pipe gives the actual dimensions of the unit being used at the Hyperion project; however, complete design details are not available.

To start the sand on its journey, a Hendy hydraulic giant is used. The giant is set from 75 to 250 feet away from the material to be moved. The giant is first set as close to the sand deposits to be moved as possible, and left there until all the material within the range of the giant has been removed. In moving sand, high-nozzle velocity is not needed, therefore it is only a matter of getting the water the required distance to the sand deposit. In operations at the Hyperion project, a No. 4 giant with a 5 -inch nozzle is used mainly. This develops a head of from about 100 to 250 feet, delivering from 590 to 1,000 cubic feet of water per minute to the area of operation. At times, it has been more adaptable to use two hydraulic giants at a point of operation. At such times, the size of each giant nozzle is reduced so that the flow of water will be equal to that used by the 5 -inch nozzle. The reason for this is the design of the eductor system -- one eductor will handle only the water from one 5-inch nozzle. Each giant is mounted on a skid to make it easy to move in sandy areas.

The eductor is located at the base of the slope in a basin formed by pushing up a barricade of sand about three sides of it, thus letting the water from the giant mixed with the sand flow downgrade and into the basin in which the eductor is located. The slope to the eductor must be great enough so that the velocity of the material will create enough turbulence to hold the sand in suspension. The eductor consists of a square box, tapered towards the base, with an open top and partially open sides. The side sections of the box are made of 0.5 -inch plate; the end sections are made of 0.875 -inch plate for rigidity. Suspended material flows down into this box and into a venturi pipe connected to the box. A high-pressure line enters into the opposite side of the box, approximately 12 inches 
from the venturi opening. Water at from 65 to 125 pounds per square inch pressure is jetted directly into the pipe opening, thus forcing the material through the pipe. An eductor is considered to have a maximum water efficiency of 30 percent in lifting; however, in the present situation the efficiency is greatly increased as the necessary height to which the water must be lifted is small, and after reaching the height desired, the slope is then downgrade. This creates a certain amount of suction, thus making for a greater efficiency in the system. The actual water efficiency of these eductor systems is about 45 percent. The percentage by volume of suspended material being delivered to the surge pit is 13.4 percent during the best operating conditions for which results were obtained. The efficiency of an eductor is at a maximum when the eductor is just covered with a solid mass of water. If the eductor were to be used for subsurface operations, the efficiency would drop as the head of water above the jet increased. It takes about 10 feet of head to acquire 1.5 feet of lift in an eductor, thus indicating considerable power loss and thus eliminating the use of the eductor except for special operations. In the operations at the Hyperion project, the contractor was able to use an eductor to force water through 3,600 feet of pipe with a 4-foot drop in elevation, which indicates that material can be delivered a long distance on nearly level ground with an eductor. - At the Hyperion project, for all grades under 4 percent, an eductor is in operation. For grades of 4 percent or greater, a sluice pipe arrangement is used where gravity flow carries the material to the.sump pit. However, to protect the entrance to the sluice line from sanding up, a jet of water from a 2.5-inch line extending from the high-pressure line is set to discharge directly into the intake opening of the sluice line. The efficiency or the percent by volume of suspended material through the sluice line during the best operating conditions noted was 21 percent. Eductors are manufactured by Schutte \& Koerting and by Joshua Hendy Iron Works. The Hyperion project is using units of a design similar to the Schutte \& Koerting.

Approximately 11,200 feet northward along the beach from the main pumping station is located the booster station, which is a semipermanent structure of sheet metal, with motors and pumps mounted on concrete bases. In this station are two 28-inch pumps, one a Fort Peck and the other a Meckum Engineering Company pump. Both are driven by General Electric motors and both pumps and motors are of the same type as the pumps in the main pumphouse. Due to the length of the pipes and the various frictions developed, the pressure of the material in the line has dropped from 155 pounds per square inch to from 5 inches of vacuum to 15 pounds per square inch pressure at the booster station. These pumps are installed and connected so that both pumps can be bypassed, or either of the two pumps can be used separately, or both pumps can be operated in series. When one pump is in operation, the pressure is built up to from 80 to 90 pounds per square inch. When both pumps are in operation, the pressure is increased to 155 pounds per square inch, the number of pumps in operation being dependent on the length of the discharge line and the amount of material in suspension being delivered. The booster station also contains auxiliary equipment for the efficient handling and operation of the pumps 
and motors. In pumping the suspended sand materials through the system, a considerable maintenance problem is encountered in that the abrasive action of the sand is continually cutting the impeller, the liners and the pump casing to a dangerous degree. Once each 7 to 10 days it is necessary to overhaul the sand pumps and build up the impeller and case for satisfactory operation. $(300,000$ to 440,000 cubic yards $)$

At the end of the discharge line, the line branches into two sections with gate valves before and after each branch. In laying a section of beach, the outboard line or sea line is opened up first and a small "peninsula" is formed along the beach edge. When the sand flow has sloped to the previous fill, the outboard line is shut off and the inboard line is opened to fill the section between the "peninsula" and the shore. The discharge is equipped with a spoon-shaped fitting which flares the material out over a wide area, thus eliminating the digging and channel forming action which would ordinarily occur.

\section{PLANT OPERATION AND DATA}

A study of plant operation can be stated only in generalities; accurate data of actual plant operating time, breakdowns, and the daily or weekly quantities of sand moved are not available. The basis of this study is on a 24-hour day, 6-day week schedule, barring unforeseen breakdowns and shutdowns and modification of plant equipment. In general, the sand pumps are repaired on the seventh day of each week by either replacing the liners and impellers or by building them up to obtain additional use. The water pumps do not need any extensive repair, as there is little abrasion or wear on the liners and impellers. Other causes of breakdown are: overheating of electric equipment, breaking of high-pressure lines, and loading of the discharge lines with trash sluiced down by the giants.

Calculations for any short period would not be accurate, therefore our results are based on monthly sand quantities moved, as furnished by the contractor. These monthly quantities are broken down into hourly quantities, for discussion purposes, and the average result is close to the general plant operation. The month taken for study was December 1947 during which best operating results were obtained as conditions were most stable, with a minimum number of breakdowns during the period. Also the actual number of operating days in this period is known. Table 1 indicates the quantity of sand moved each month during the hydraulic excavation period. These quantities were calculated by survey, making cross-sectional charts at the start of operations and at the beginning of each month thereafter, and checking the differences as gross-plant performance. As the terrain is very uneven, actual performance was difficult to determine. However, the contractor's survey and the city survey are within 5 percent of one another. During December (the period of operation was 25 days), $1,120,700$ cubic yards of material were removed and deposited. It is known that during most of this period, three giants, two eductors and one sluice pipe were in operation. Information from the contractor 
Table 1. Hyperion Excavation - Survey Interva1* (Monthly Hydraulic Quantities)

\begin{tabular}{|c|c|}
\hline Mo. - Yr. & Gross Plant Performance $\left(\mathrm{yd}^{3}\right)$ \\
\hline \hline 1947 & 350,600 \\
Mar. & 662,800 \\
Apr. & 740,510 \\
May & 741,710 \\
June & 688,635 \\
Ju1y & 506,325 \\
Aug. & 860,330 \\
Sept. & 942,265 \\
Oct. & 783,730 \\
Nov. & $1,120,760$ \\
Dec. & \\
\hline 1948 & 771,240 \\
Jan. & $8,168,905$ Total \\
\hline \multicolumn{2}{|c|}{ Average: } \\
\hline \hline
\end{tabular}


indicates that pump No. 1, the sea pump, delivers 41,000 gallons per minute at approximately 85 pounds of pressure for use by the system. No information is available on pipeline velocities, either in the water or sand lines. From the above information, the following results were calculated:

$$
\begin{aligned}
\text { Average material moved per day } & =\frac{\text { Quantity moved in period }}{\text { Operational days in period }} \\
& =\frac{1,120,700}{25}=44,828 \mathrm{yd}^{3} / \text { day }
\end{aligned}
$$

As two eductors and one flume were operating, the volume per unit per day moved was:

$$
\frac{44,828}{3}=14,943 \mathrm{yd}^{3} / \text { day } / \text { unit or } \frac{14,943}{24}=623 \mathrm{yd}^{3} / \mathrm{hr} / \text { unit }
$$

Noting the pressures at various hydraulic giant nozzles at various times during operations, it was found that the pressure averaged close to 90 pounds per square inch under above conditions. From nozzle data furnished by the Joshua Hendy Iron Works, manufacturers of the giants, the quantity of water delivered by each nozzle was calculated, using a figure of 90 percent of the theoretical flow. A nozzle for a 2.5-inch sluice pipe delivers 1,775 gallons per minute, or:

$$
\frac{1,775 \mathrm{gal} / \mathrm{min}}{7.48 \mathrm{gal} / \mathrm{ft}^{3}}=238 \mathrm{ft}^{3} / \mathrm{min}
$$

The 5.5-inch eductor nozzle delivers 8,560 gallons per minute, or:

$$
\frac{8,560 \mathrm{gal} / \mathrm{min}}{7.48 \mathrm{gal} / \mathrm{ft}^{3}}=1,142 \mathrm{ft}^{3} / \mathrm{min}
$$

The 5-inch giant nozzle (somewhat worn) delivers 7,100 gallons per mute, or:

$$
\frac{7,100 \mathrm{gal} / \mathrm{min}}{7.48 \mathrm{gal} / \mathrm{ft}^{3}}=950 \mathrm{ft}^{3} / \mathrm{min}
$$

The sand delivered per eductor line or sluice line is:

$$
\frac{623 \mathrm{gal} / \mathrm{min}}{60 \mathrm{gal} / \mathrm{ft}^{3}}=10.38 \mathrm{yd}^{3} / \mathrm{min} / \mathrm{unit}
$$


The eductor efficiency equals:

$\frac{\text { Amount of water delivered by a } 5 \text {-inch in } \mathrm{ft}^{3}}{5 \text {-inch nozzle delivery in } \mathrm{ft}^{3}+5.5 \text {-inch eductor in } \mathrm{ft}^{3}}$

$$
=\frac{950}{950+1,142}=45.5 \text { percent }
$$

This percentage is high compared with data taken from hydraulic books. However, in these particular conditions of operation, there is usually a certain amount of sluicing or siphoning effect helping. the eductor. The main function of the eductor is to force the suspended material through the pipe at a high enough velocity to keep the material in suspension. The percentage of sand in suspension in water by volume through a sluice pipe equals:

$$
\mathrm{ft}^{3} / \mathrm{sand} / \mathrm{min}
$$

Giant delivery per minute in $\mathrm{ft}^{3}+2.5$-inch flume pipe delivery per minute

$$
=\frac{10.38 \times 27}{1,142+238}=\frac{280.3}{1,380}=20.3 \text { percent }
$$

The percentage of sand suspension by volume through the eductor equals:

$$
\mathrm{ft}^{3} / \mathrm{min}
$$

Giant volume per minute in $\mathrm{ft}^{3}+$ eductor volume per minute in $\mathrm{ft}^{3}$

$$
=\frac{10.38 \times 27}{1,142+950}=\frac{280.3}{2,092}=13.4 \text { percent }
$$

To determine the total plant efficiency, the operation of the three units must be combined. The efficiency is equal to:

$$
\begin{gathered}
\frac{\mathrm{ft}^{3} \text { sand moved per day }}{\text { Total volume of water used } \mathrm{ft}^{3} / \mathrm{day}^{2}} \\
=\frac{45,000 \mathrm{yd}^{3} / \mathrm{day} \times 7,148 \mathrm{gal} / \mathrm{ft}^{3} \times 27 \mathrm{ft}^{3} / \mathrm{yd}^{3}}{41,000 \mathrm{gal} / \mathrm{min} \times 1,440 \mathrm{~min} / \mathrm{day}^{3}}=15.4 \text { percent }
\end{gathered}
$$

The total amount of sand moved during the operations from March 1947 through January 1948 was 8,168,905 cubic yards; best results were recorded during December. It is impractical to convert these figures to plant efficiency over this period, as the total number of plant operating hours is not known, and the general operating conditions have varied extremely during this period, as shown by the photographs (see Figures). Both the water lines and the sand lines have been elongated considerably. In the discharge line, it has been necessary to add a booster station to deliver the suspended material to the desired locations. This booster station was located at a 
point where the pressure in the discharge line had reduced because of pipe friction from 155 pounds per square inch to 0 to 2 pounds per square inch pressure.

Table 2 records actual pump-operating data taken during various visits to the operation. From these figures, the average power consumption and horsepower used to operate the pumps in the system can be computed. Table 3 lists averages of data on Table 2 with calculations for horsepower consumption, percent of load, and efficiency of operations.

The contractor's time rolls were not available for checking the number of employees engaged on the project. However, by actual count, during project inspection, a total of 76 personnel consisted of the following:

1 - job engineer

1 - assistant engineer

2 - engineering aides

1 - accountant

1 - purchasing agent

2 - office girls

1 - field superintendent

6 - foremen; 2 per shift

15 - field operating men; 5 per shift

1 - caterpillar tractor operator

3 - surge pit operators; 1 per shift

12 - men in booster station; 4 per shift

6 - men on pipeline maintenance; 2 per shift

24 - main pumphouse operators (welders, operations and maintenance men);

8 per shift

\section{CONCLUSIONS}

Use and operation of the hydraulic method for moving sand is considered economical in this particular location and for these special types of operations. Here, the contractor received 22.6 cents per cubic yard for the removal and disposal of 14,000,000 cubic yards of material. The system is economical only in locations where a satisfactory quantity of sand is close by. The pumping equipment is a semipermanent installation, mounted on concrete foundations, thus making the cost of frequently changing location prohibitive. The system must also be located near a large source of water that is easily available for use. The installation would not be advisable for small operations, because initial installation cost is high. If only a small amount of material were to be moved, the cost of installation and operation combined would make the yardage cost prohibitive. 
Table 2. E1 Segundo Pumping Plant - Operational Data

\begin{tabular}{|c|c|c|c|c|c|c|c|}
\hline Date & $\begin{array}{l}\text { Purpp } \\
\text { No: }\end{array}$ & $\begin{array}{l}\text { Yacuum } \\
\text { (in) }\end{array}$ & $\begin{array}{c}\text { Pressure } \\
\left(1 \mathrm{~b} / \mathrm{in}^{2}\right)\end{array}$ & $r / \min$ & a.c. V & $\mathrm{kV}$ & $\mathbf{k W}$ \\
\hline $\begin{array}{c}1947 \\
17 \text { Dec. } \\
\left(11: 30 \mathrm{a} . \mathrm{m}_{.}\right) \\
\left(2: 30 \mathrm{p} \cdot \mathrm{m}_{\circ}\right)\end{array}$ & $\begin{array}{c}1 \\
2 \\
3 \\
1 \\
2 \\
3 \\
4 \\
\text { booster }\end{array}$ & $\begin{array}{c}22 \\
-- \\
4 \\
24 \\
-\infty \\
0 \text { to } 5 \\
-\overline{P S I}(P) *\end{array}$ & $\begin{array}{r}76 \\
155 \\
74 \\
78 \\
157 \\
80 \\
137 \\
100\end{array}$ & $\begin{array}{l}251 \\
252 \\
240 \\
253 \\
250 \\
240 \\
240 \\
240 \\
\end{array}$ & $\begin{array}{l}198 \\
198 \\
205 \\
200 \\
200 \\
205 \\
205 \\
262 \\
\end{array}$ & $\begin{array}{l}4300 \\
4300 \\
4200 \\
4250 \\
4250 \\
4200 \\
4200 \\
4100 \\
\end{array}$ & $\begin{array}{l}2850 \\
2350 \\
1850 \\
2850 \\
2400 \\
2320 \\
1980 \\
2400 \\
\end{array}$ \\
\hline 29 Dec. & $\begin{array}{c}1 \\
2 \\
3 \\
4 \\
\text { booster } \\
\end{array}$ & $\begin{array}{l}24 \\
0 \text { to } 2 \\
=- \\
6 \text { PSI }(P) \text { * }\end{array}$ & $\begin{array}{r}78 \\
155 \\
78 \\
158 \\
100 \\
\end{array}$ & $\begin{array}{l}265 \\
253 \\
230 \\
238 \\
240 \\
\end{array}$ & $\begin{array}{l}197 \\
197 \\
198 \\
198 \\
262 \\
\end{array}$ & $\begin{array}{l}4200 \\
4200 \\
4050 \\
4050 \\
4100 \\
\end{array}$ & $\begin{array}{l}2450 \\
2980 \\
2150 \\
2180 \\
2400 \\
\end{array}$ \\
\hline $\begin{array}{r}1948 \\
5 \text { Jan. }\end{array}$ & $\begin{array}{c}1 \\
2 \\
3 \\
4 \\
\text { booster }\end{array}$ & $\begin{array}{r}20 \\
-- \\
0 \\
-- \\
12 \text { PSI }(P) * \\
\end{array}$ & $\begin{array}{r}86 \\
160 \\
85 \\
170 \\
115 \\
\end{array}$ & $\begin{array}{l}265 \\
255 \\
225 \\
242 \\
238 \\
\end{array}$ & $\begin{array}{l}210 \\
210 \\
218 \\
218 \\
262 \\
\end{array}$ & $\begin{array}{l}4200 \\
4200 \\
4225 \\
4225 \\
4300 \\
\end{array}$ & $\begin{array}{l}2300 \\
2800 \\
2000 \\
2150 \\
2550 \\
\end{array}$ \\
\hline $6 \mathrm{Jan}$. & $\begin{array}{c}1 \\
2 \\
3 \\
4 \\
\text { booster } \\
\end{array}$ & $\begin{aligned} 22 \\
-- \\
2 \\
-7 \text { PSI } \\
\end{aligned}$ & $\begin{array}{r}80 \\
158 \\
80 \\
158 \\
95 \\
\end{array}$ & $\begin{array}{l}257 \\
253 \\
228 \\
243 \\
250 \\
\end{array}$ & $\begin{array}{l}200 \\
200 \\
228 \\
228 \\
260 \\
\end{array}$ & $\begin{array}{l}4250 \\
4250 \\
4200 \\
4200 \\
4300 \\
\end{array}$ & $\begin{array}{l}1980 \\
2100 \\
2350\end{array}$ \\
\hline $8 \mathrm{Jan}$. & $\begin{array}{c}1 \\
2 \\
3 \\
4 \\
\text { booster } \\
\end{array}$ & $\begin{array}{c}18 \text { to } 20 \\
-- \\
1 \text { to } 3 \\
-2 \text { to } 3 \text { PSI }(\mathrm{P}) \text { * }\end{array}$ & $\begin{array}{r}80 \\
160 \\
83 \\
165 \\
103 \\
\end{array}$ & $\begin{array}{l}255 \\
260 \\
230 \\
240 \\
240 \\
\end{array}$ & $\begin{array}{l}210 \\
210 \\
218 \\
218 \\
275 \\
\end{array}$ & $\begin{array}{l}4200 \\
4200 \\
4050 \\
4050 \\
4900 \\
\end{array}$ & $\begin{array}{l}2200 \\
2650 \\
2120 \\
2400 \\
2450 \\
\end{array}$ \\
\hline $13 \mathrm{Jan}$. & $\begin{array}{c}1 \\
2 \\
3 \\
4 \\
\text { booster } \\
\end{array}$ & $\begin{array}{l}21 \\
0 \text { to } 5 \\
12 \text { PSI }(\mathrm{P})^{*}\end{array}$ & $\begin{array}{r}75 \\
158 \\
72 \\
150 \\
100 \\
\end{array}$ & $\begin{array}{l}252 \\
252 \\
228 \\
240 \\
255 \\
\end{array}$ & $\begin{array}{l}207 \\
207 \\
212 \\
212 \\
260 \\
\end{array}$ & $\begin{array}{l}4200 \\
4200 \\
4000 \\
4000 \\
4500 \\
\end{array}$ & $\begin{array}{l}2350 \\
2850 \\
2100 \\
2050 \\
2300 \\
\end{array}$ \\
\hline 19 Jan. & $\begin{array}{l}1 \\
2 \\
3 \\
4 \\
5 \\
6\end{array}$ & $\begin{array}{c}16 \text { to } 19 \\
0 \text { to } 1 \\
0 \text { to } 5 \\
\ldots\end{array}$ & $\begin{array}{r}80 \\
162 \\
87 \\
173 \\
83 \\
115 \\
\end{array}$ & $\begin{array}{l}258 \\
252 \\
230 \\
250 \\
250 \\
210 \\
\end{array}$ & $\begin{array}{l}212 \\
212 \\
212 \\
212 \\
252 \\
252 \\
\end{array}$ & $\begin{array}{l}4200 \\
4200 \\
4050 \\
4050 \\
4200 \\
4200 \\
\end{array}$ & $\begin{array}{l}2000 \\
2450 \\
2320 \\
2200 \\
1600 \\
1570 \\
\end{array}$ \\
\hline $20 \mathrm{Jan}$. & $\begin{array}{l}1 \\
2 \\
3 \\
4 \\
5 \\
6\end{array}$ & $\begin{array}{c}20 \text { to } 21 \\
-- \\
0 \\
-- \\
3 \text { to } 5 \\
--\end{array}$ & $\begin{array}{r}82 \\
160 \\
75 \\
155 \\
85 \\
115 \\
\end{array}$ & $\begin{array}{l}258 \\
255 \\
206 \\
241 \\
255 \\
198\end{array}$ & $\begin{array}{l}212 \\
212 \\
220 \\
220 \\
255 \\
255\end{array}$ & $\begin{array}{l}4200 \\
4200 \\
4100 \\
4100 \\
4230 \\
4230\end{array}$ & $\begin{array}{l}2150 \\
2700 \\
1830 \\
2100 \\
1580 \\
1550\end{array}$ \\
\hline
\end{tabular}

- PSI a $1 \mathrm{~b} / \mathrm{in}^{2} ;(\mathrm{P})=$ Pressurf 
Table 3. Average of Readings

\begin{tabular}{|c|c|c|c|c|c|c|}
\hline $\begin{array}{l}\text { Pump } \\
\text { No. }\end{array}$ & $\begin{array}{l}\text { Motor } \\
\text { input } \\
(\mathrm{kW})\end{array}$ & $\begin{array}{l}\text { Pressure } \\
\left(1 b / i^{2}\right)\end{array}$ & $\begin{array}{l}\text { Motor } \\
\text { input* } \\
\text { (hp) }\end{array}$ & $\begin{array}{l}\text { Motor } \\
\text { loadt } \\
\text { (pct) }\end{array}$ & $\begin{array}{l}\text { Water } \ddagger \\
\text { (hp) }\end{array}$ & $\begin{array}{c}\text { Unit } \\
\text { efficiency }\end{array}$ \\
\hline 1 & 2394 & 80.2 & 3209 & 122 & 1967 & 61.3 \\
\hline 2 & 2648 & 78.1 & 3550 & 142 & 1915 & 53.9 \\
\hline 3 & 2074 & 79.3 & 2780 & 111 & $\S$ & $\S$ \\
\hline 4 & 2118 & 76.7 & 2839 & 114 & $\S$ & $\xi$ \\
\hline $5 \|$ & 2358 & 93.0 & 3161 & 126 & $\S$ & $\S$ \\
\hline $5 \pi$ & 1590 & 84.1 & 2131 & 85 & § & $\S$ \\
\hline 6 & 1560 & 31.0 & 2091 & 84 & ฐ & $\S$ \\
\hline
\end{tabular}

*Motor $\mathrm{hp}=\frac{\mathrm{kW} \text { input }}{0.746}$

+Motor load $=\frac{\text { Actual input }}{\text { Rated input }}$

$\ddagger$ Water $\mathrm{hp}=\frac{\mathrm{ft}^{3} / \mathrm{s} X \text { wt of water } X \text { head in } \mathrm{ft}}{550}$

$\S$ Not calculated because of number of unknown variables,eg. weight, slurry, and water losses.

II Single operation

ISeries operation 
The position must be such that there will be zero grade or better for short runs, with proportionately higher grades for long runs. At this project, with a slope of 4 feet in 3,000 feet ( 1 on 750 ), the contractor has been able to deliver a satisfactory amount of material to the surge pit. Any further increase in slope causes difficulty in delivery of material, as the lines sand up, causing breakdowns in the system. Where the depositing area is higher than the area from which the sand is to be removed, the sand eductor system is not satisfactory as the efficiency of an eductor is poor. Also, in locations with deposits of clay, shale, or other solid materials which remain consolidated underwater, a jet would not be suitable for this type of operation.

To maintain efficient operation in the pumping system, the center line of primary water and sand pumps must be located so there is a minimum amount of suction lift. Also, the location must be such that the discharge from the surge pit is slightly above the pump centerline to provide a velocity that will keep the sluice material in suspension. This limits the advisability of the use of the system in many locations. At the E1 Segundo plant, it was necessary to locate pumps No. 1 and 3 below grade line, to reduce the suction lift from the ocean and to obtain the necessary drop from the surge pit, to improve total plant efficiency. If this had not been done, the delivery rate of pump No. 1 would have been lowered, and the amount of material in suspension received by pump No. 3 would also have been lowered, thus reducing the total plant efficiency.

A system designed for utilizing the sand eductor as a prime mover for transferring sand or soil from point to point would have extreme application limitations, for the following reasons:

1. The eductor has no mechanical means of agitation for mixing the sand with water; therefore, the material must be delivered to the eductor with the sand or soil suspended in the water at a correct mixture to be siphoned in by the eductor and forced through the discharge line economically. If the mixture is too heavy, settlement and clogging of the discharge lines will occur; if the mixture is too light, too much energy is dissipated in pumping water.

2. The maximum length of discharge line through which material was forced by an eductor satisfactorily on the Hyperion project was 3,000 feet and this was with a 4 -foot drop in elevation and with a mximum pressure of 90 pounds per square inch, which was the pressure available for use with the equipment on hand. This limits the installation to locations where a drop of 1.33 feet or more per 1,000 feet could be obtained in the discharge lines, and the deposit area must be located within a 3,000-foot radius from the borrow pit. If the length of discharge line is greater than stated above, the material in suspension will settle to the bottom of the line, thus sanding up the line and stopping the flow of water, unless a system with higher water pressures with resultant greater nozzle velocities is used. To force the suspended material a greater distance, the pressure of water delivered by the pump to the eductor nozzle must be increased to obtain higher velocity and prevent settling of the material 
and clogging of the discharge lines. It would also probably be necessary to increase the size of the discharge lines to assist in maintaining a higher velocity throughout the lines, by reason of decrease in friction component. The above information indicates that in laying out an eductor system, the prime design consideration is that the velocity throughout the sand lines must always be great enough to keep the suspended material from settling and sanding up the discharge line.

3. Since the sand or soil must be delivered to the eductor suspended in water, a hydraulic giant or similar equipment for jetting and dislodging the material from the borrow pit and sluicing it down to the eductor is required. The location of the borrow pit with the required quantity of material must have an elevation above the eductor sufficient to provide adequate drop for sluicing the material down to the eductor.

The' Figures (photos) show the progress of the operations from their start to the present time, indicating the transformation that has occurred both at the area where the sand was taken and the area where it was deposited. The material has been removed from three separate areas in the same location. At the point of this writing, these three locations are commencing to blend into one large removal area. The present area of depositing material is about 1 mile north of Ballona Creek. 


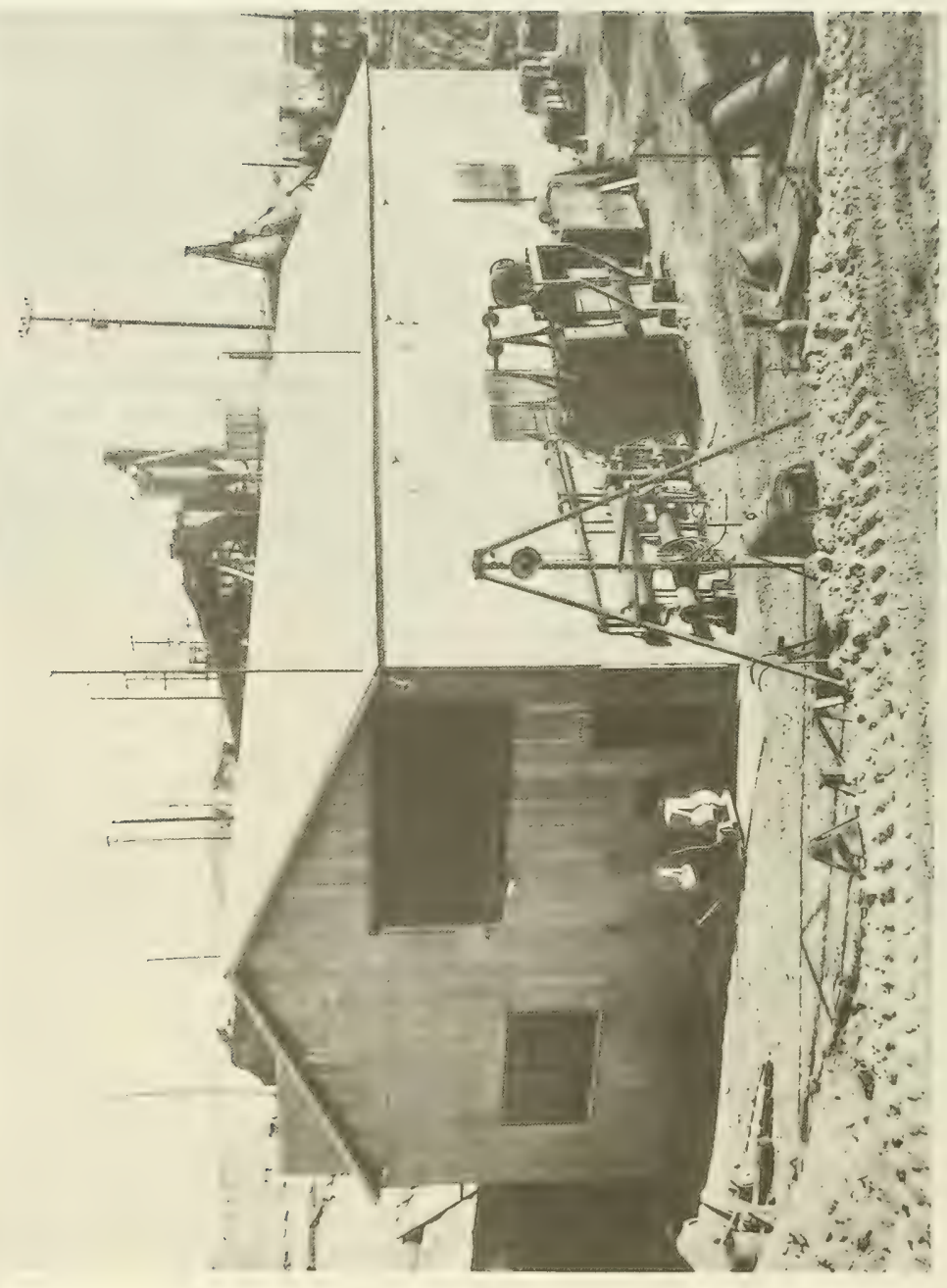

雚

है

i

(1)

है음

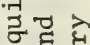

क तี

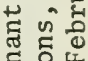

드으

茂

ङ

त्र हैं

क्ष

हु

的 폼을 3 당 0)

क 0 วิ 든 声的 ᄃ 들 त् (t) 4 -

- लै $+0$ 로 종

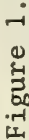




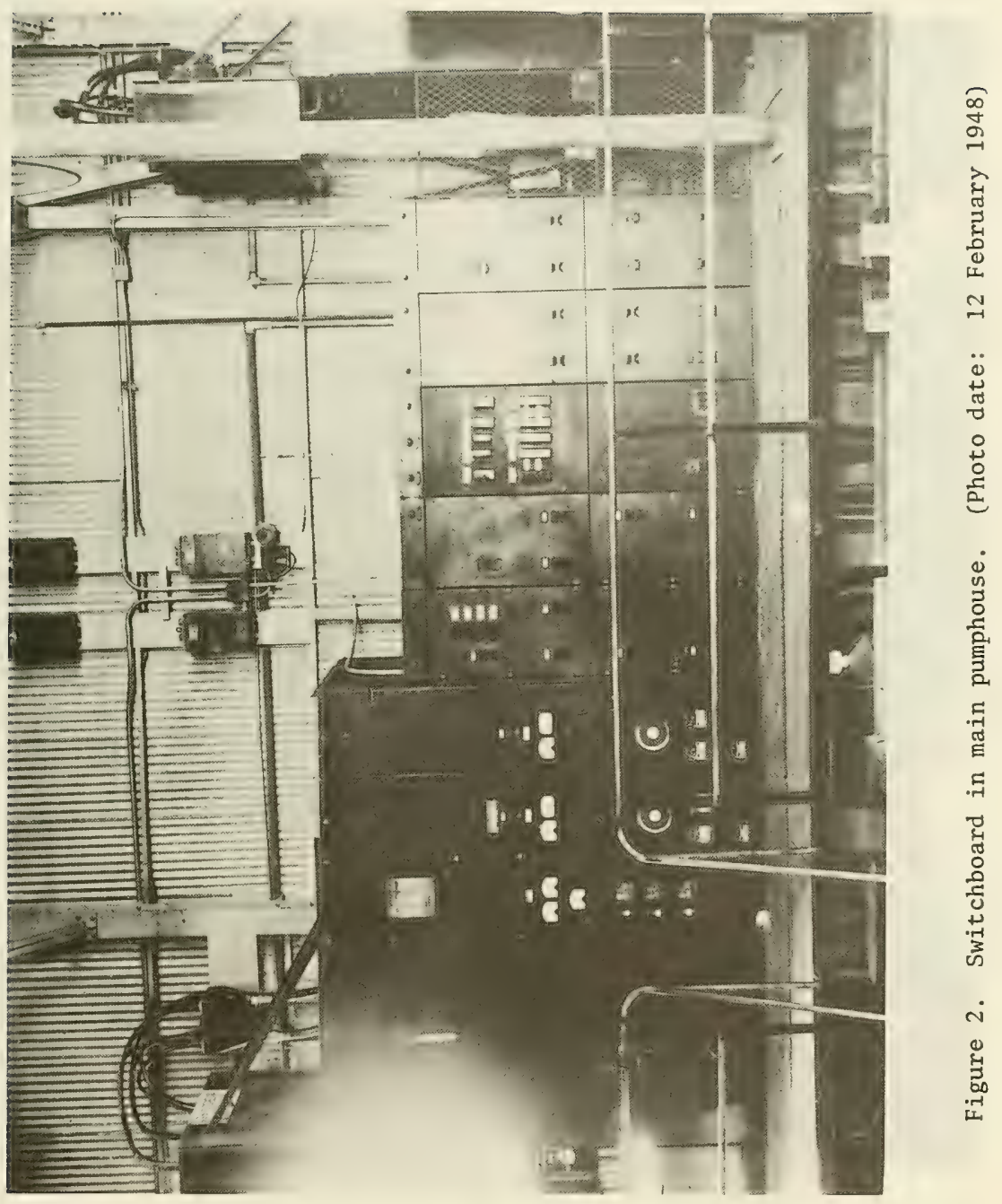




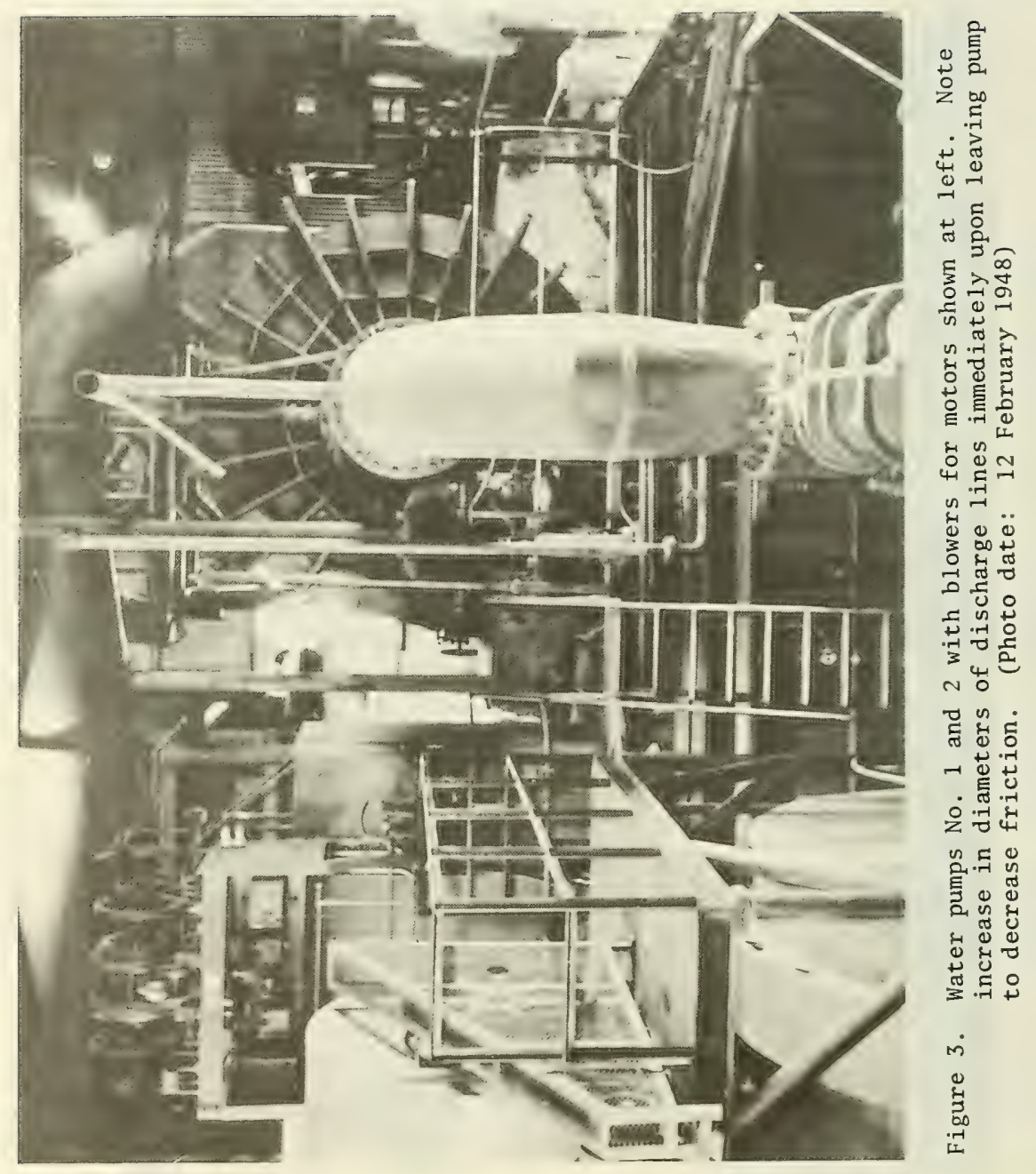




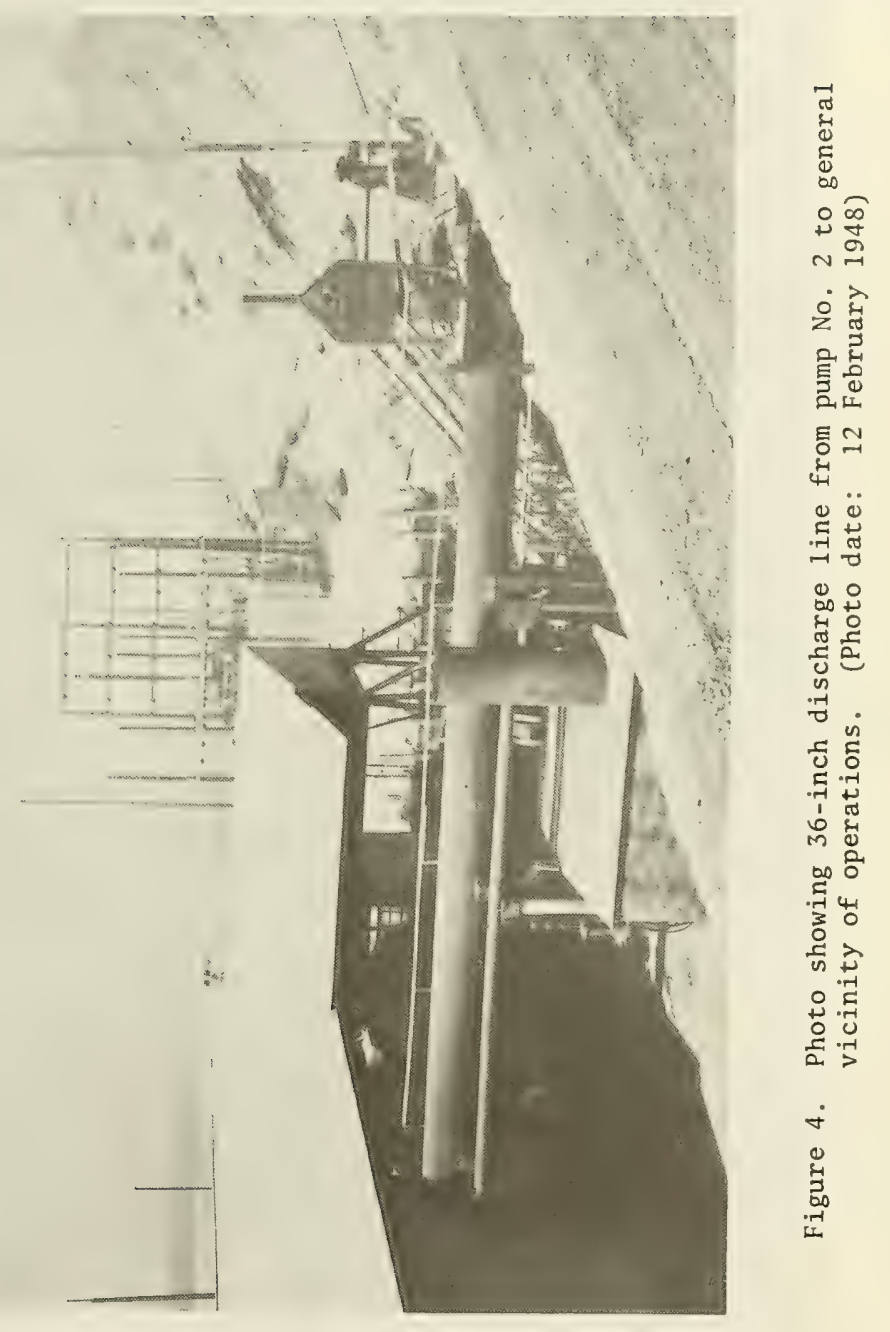




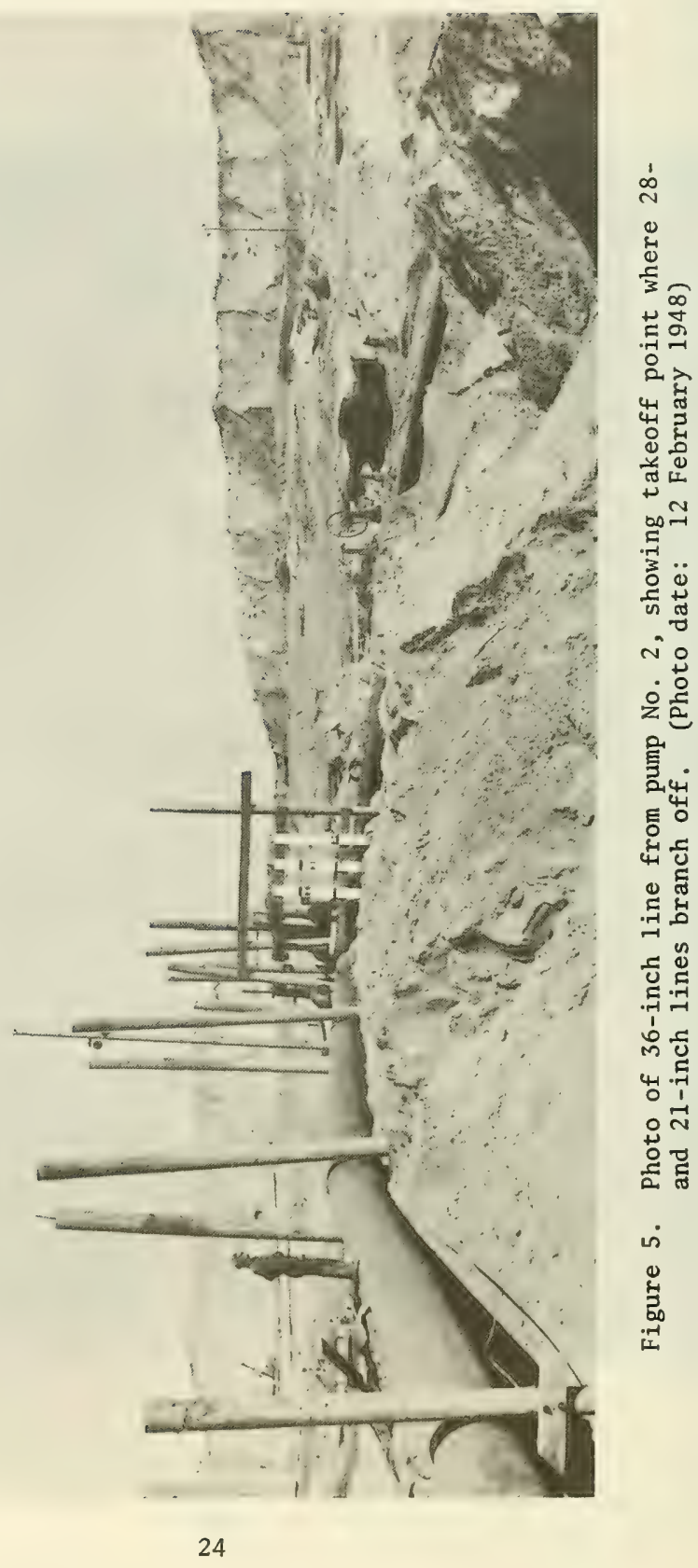




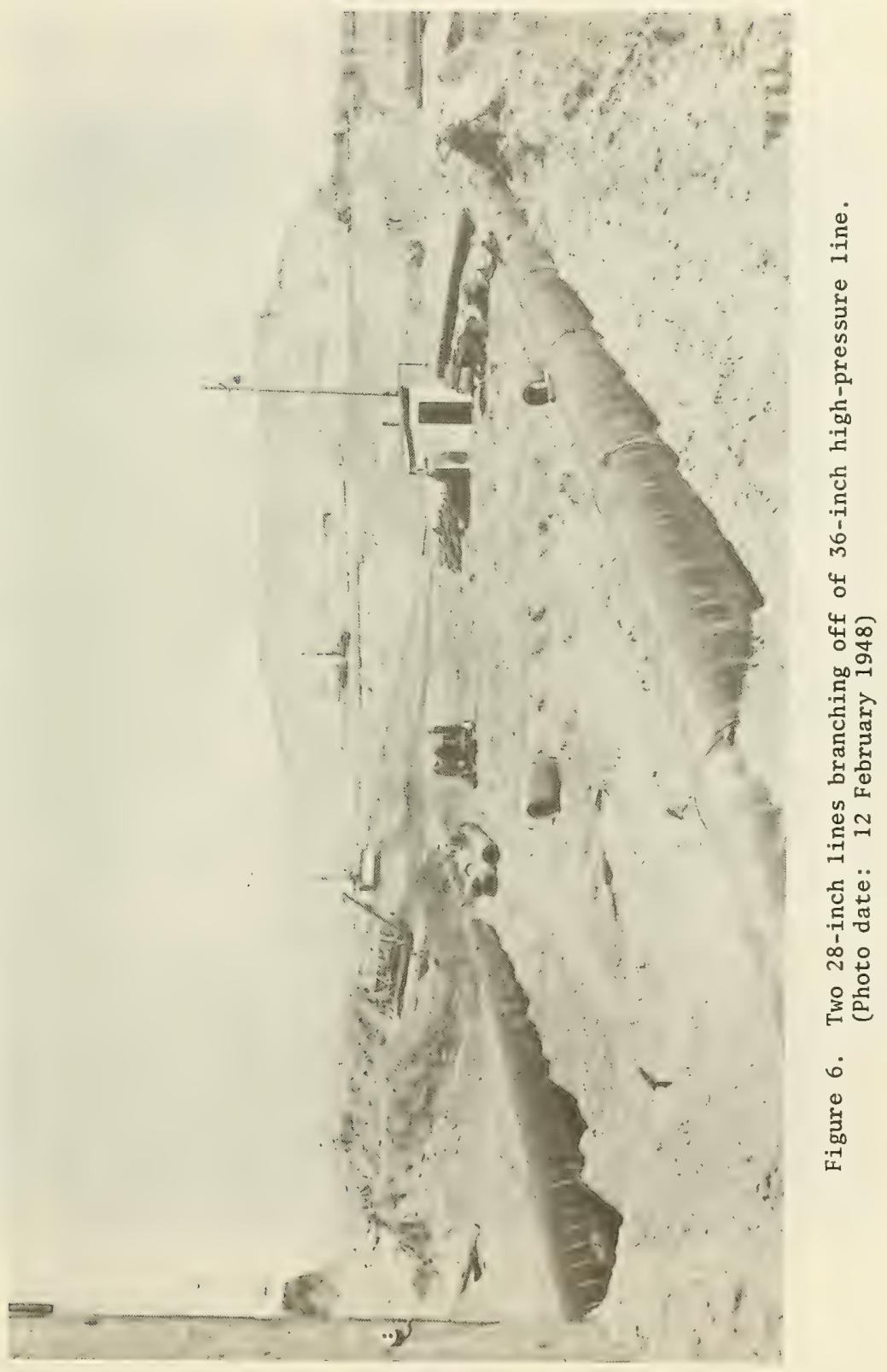




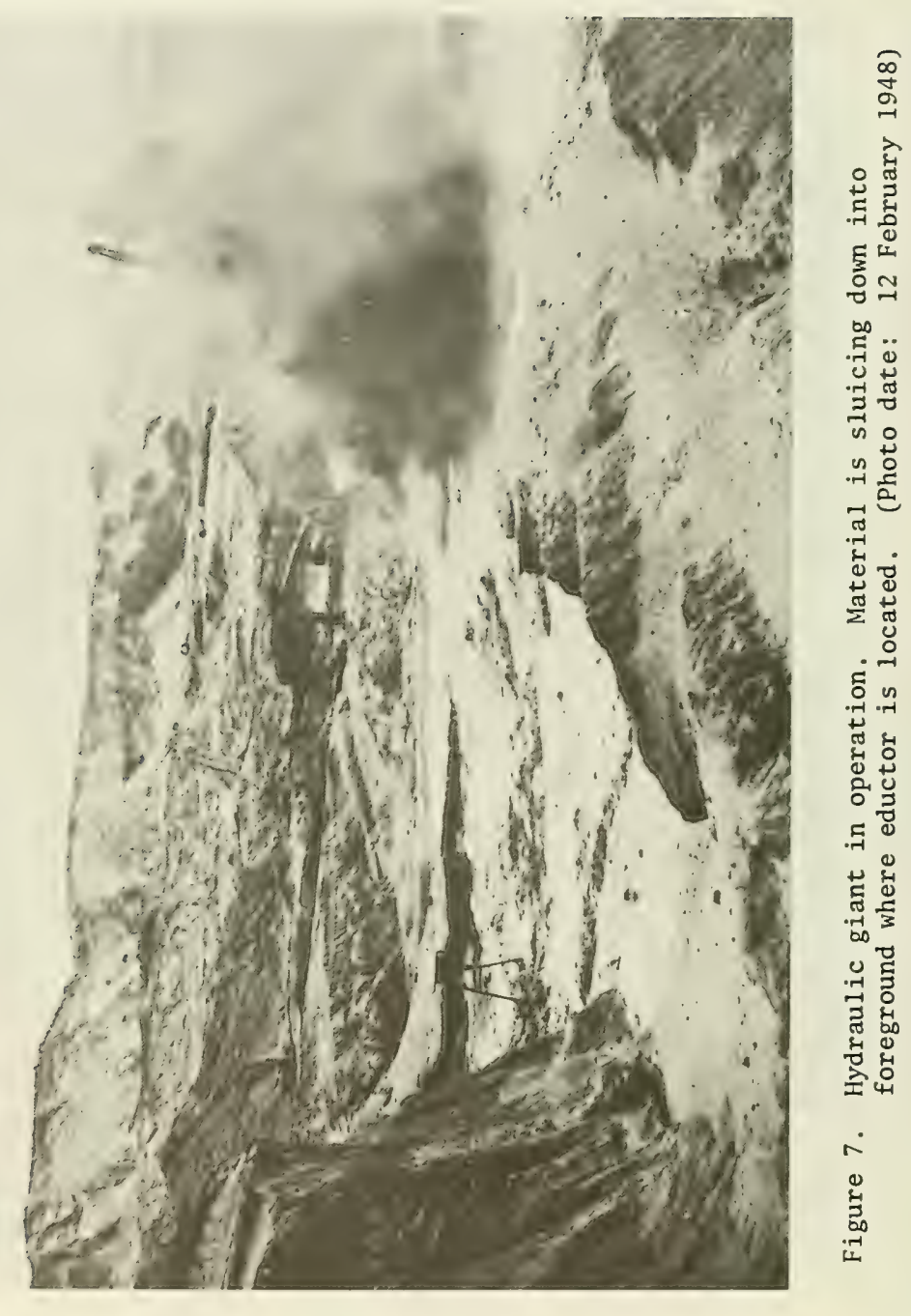




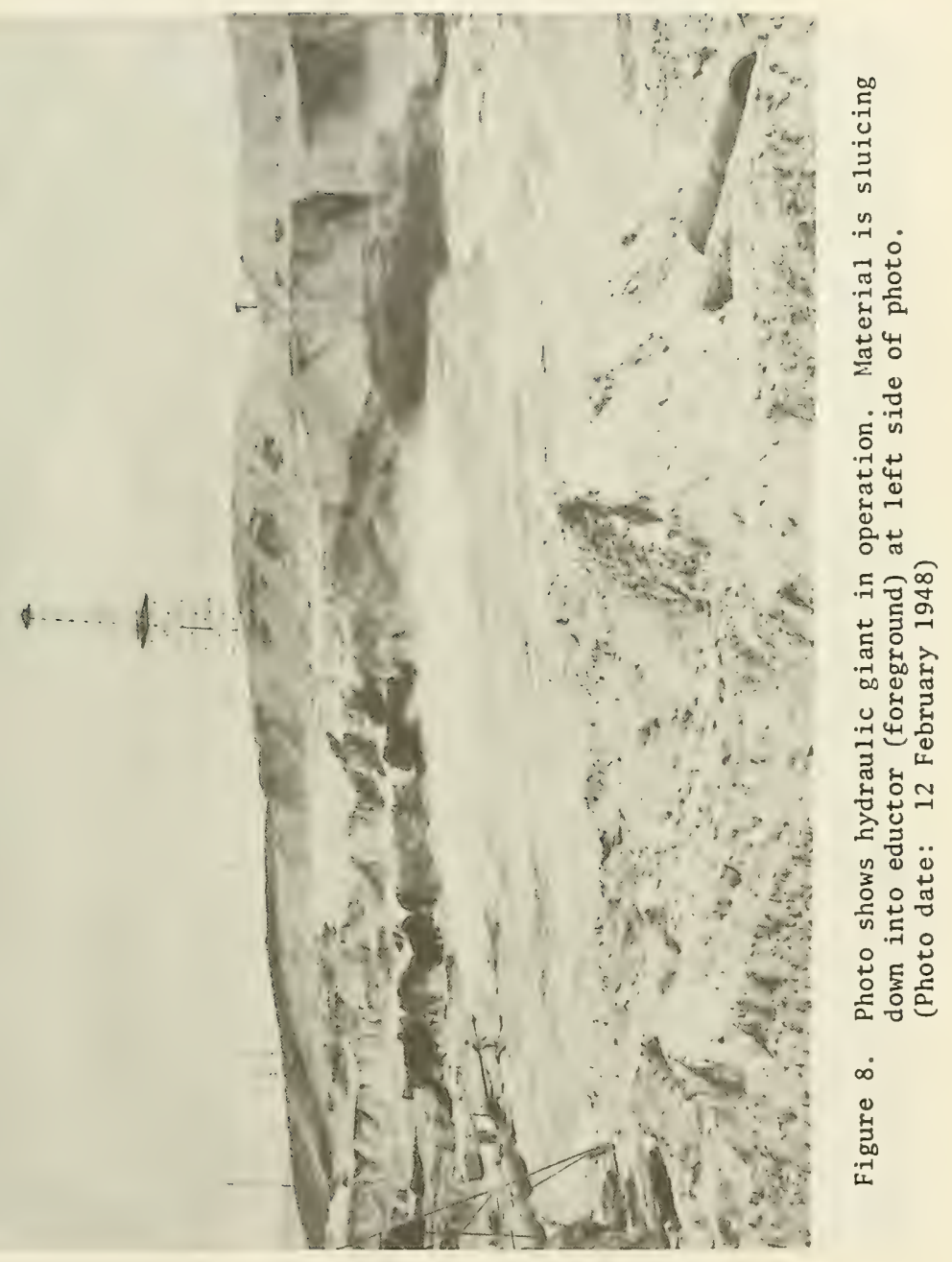




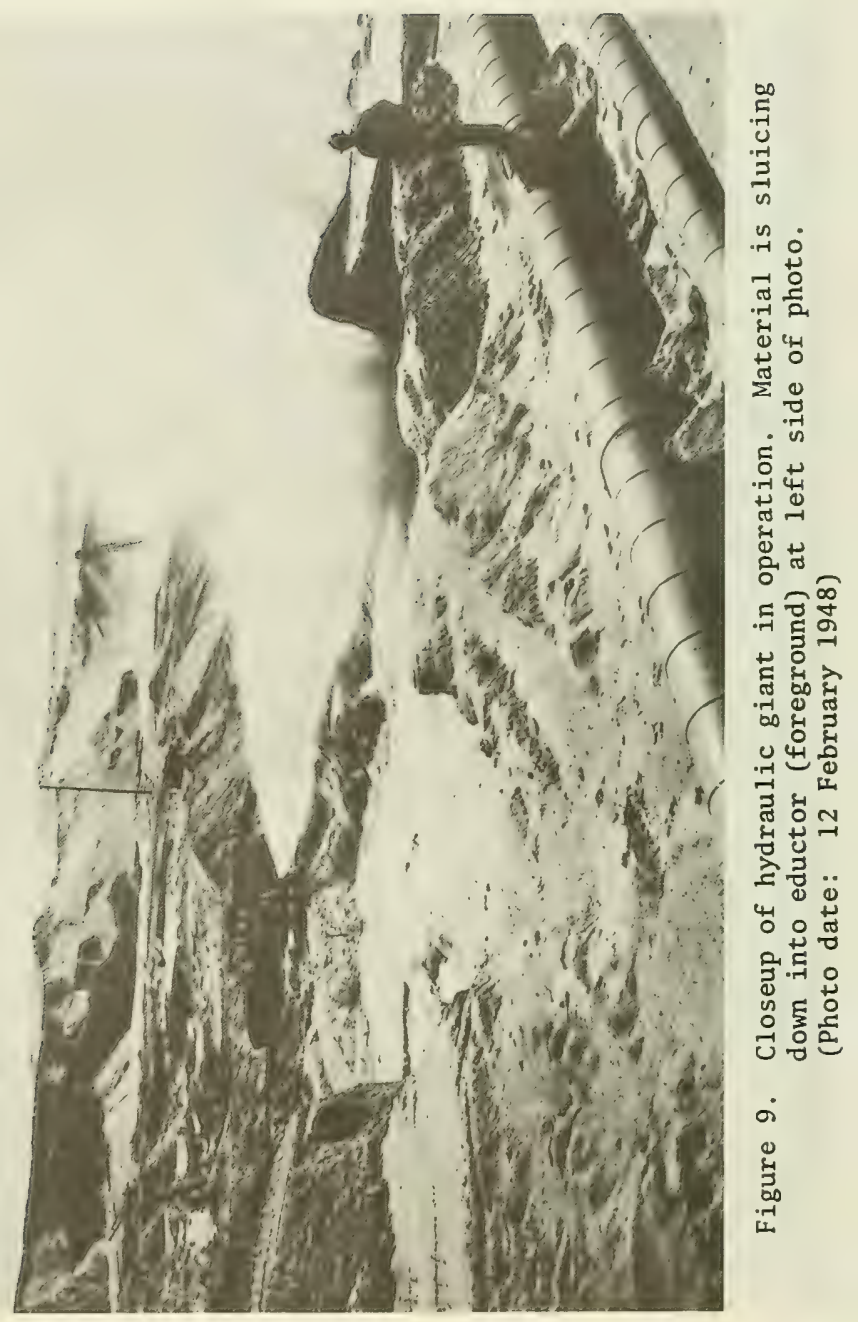




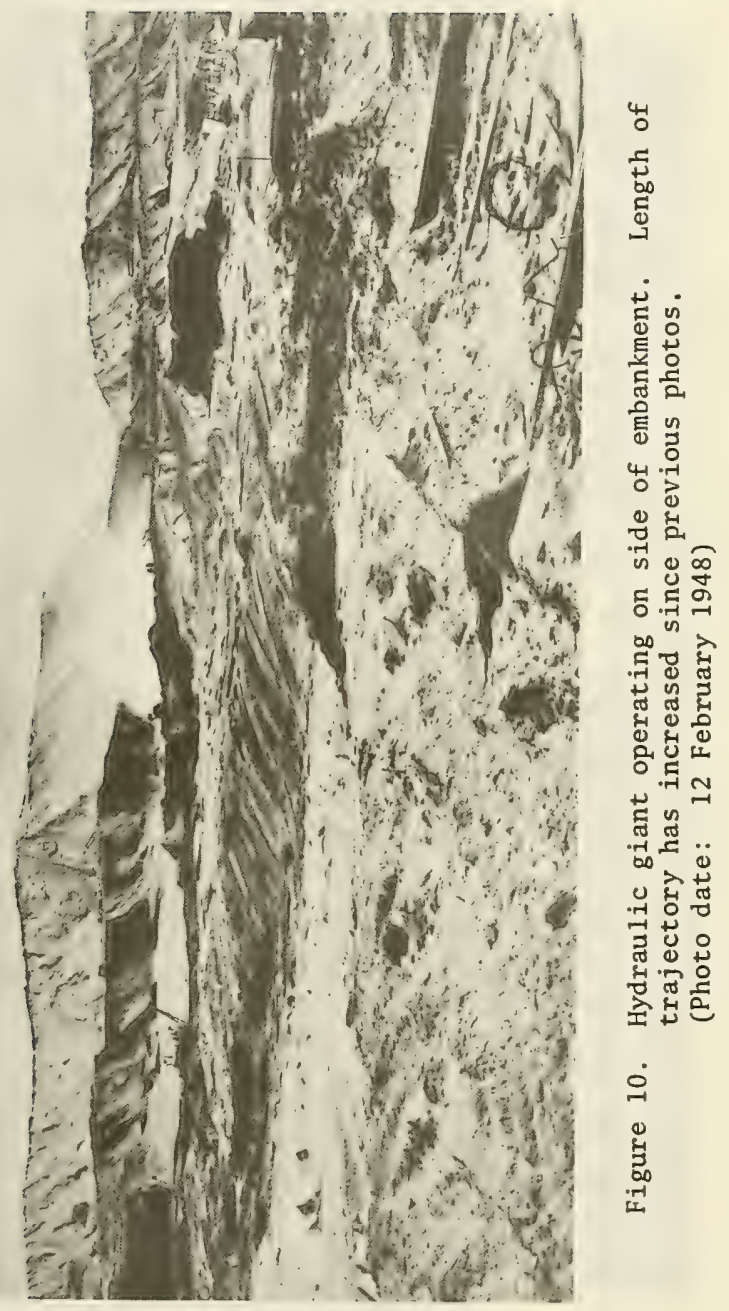




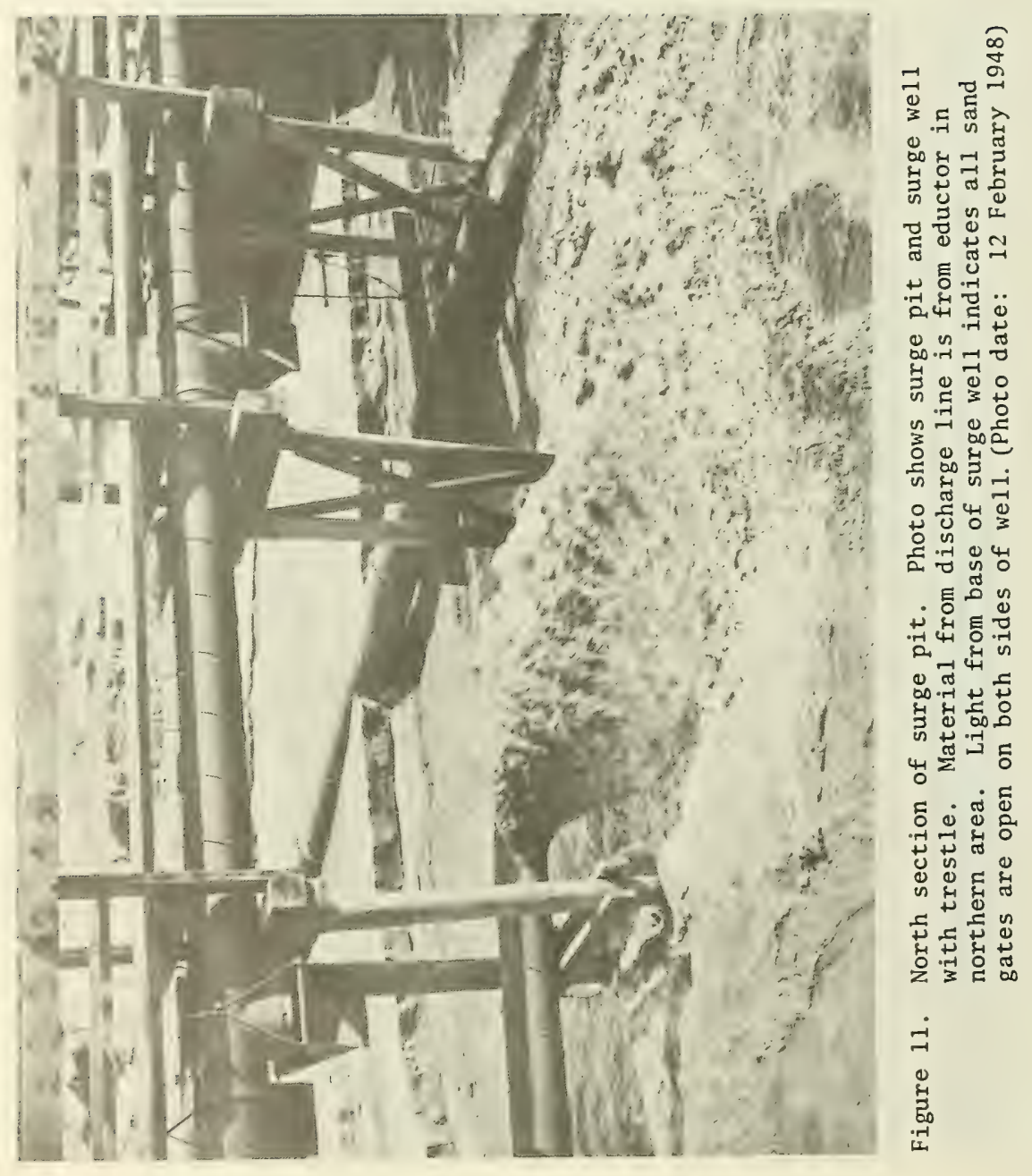




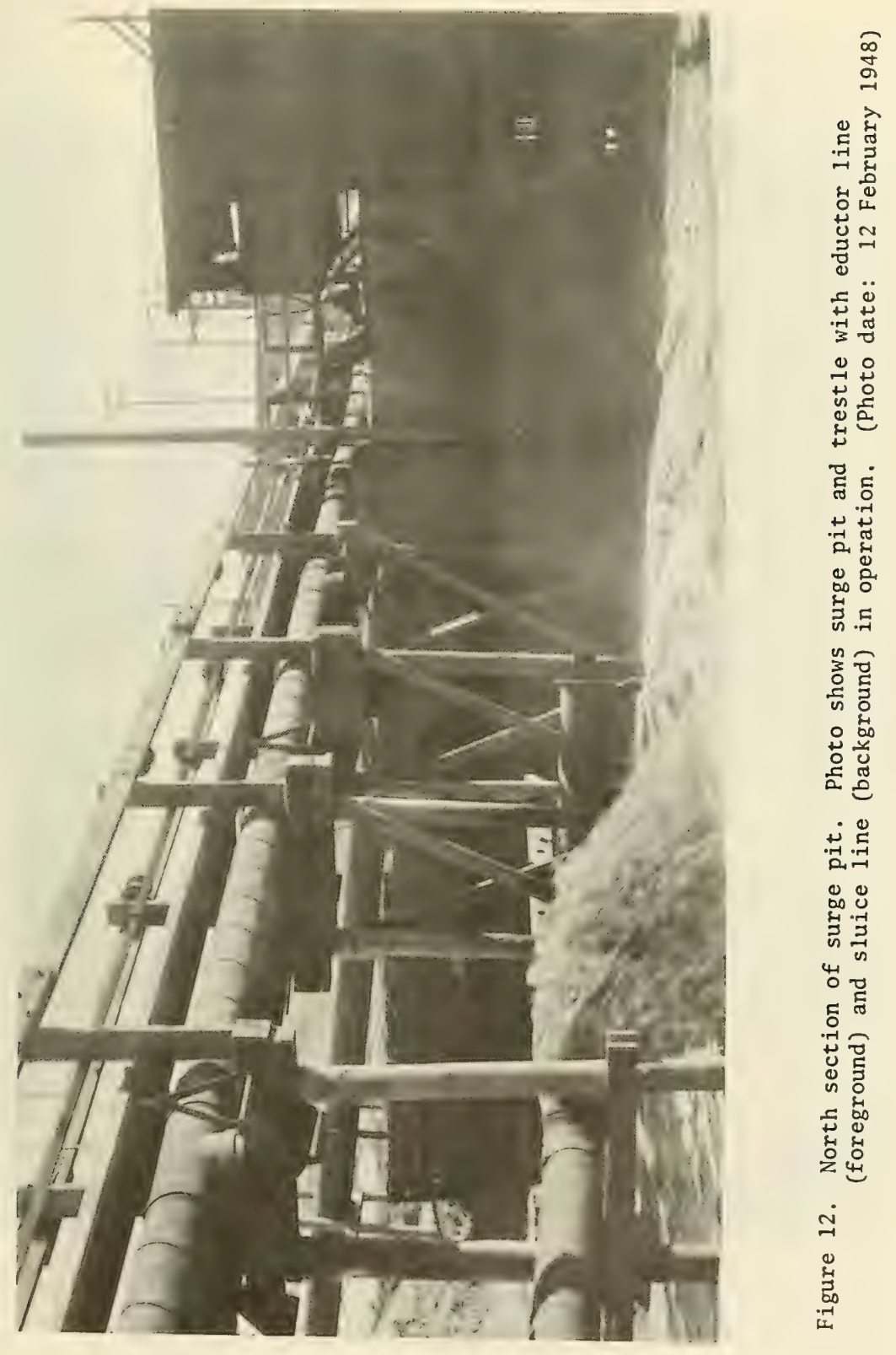




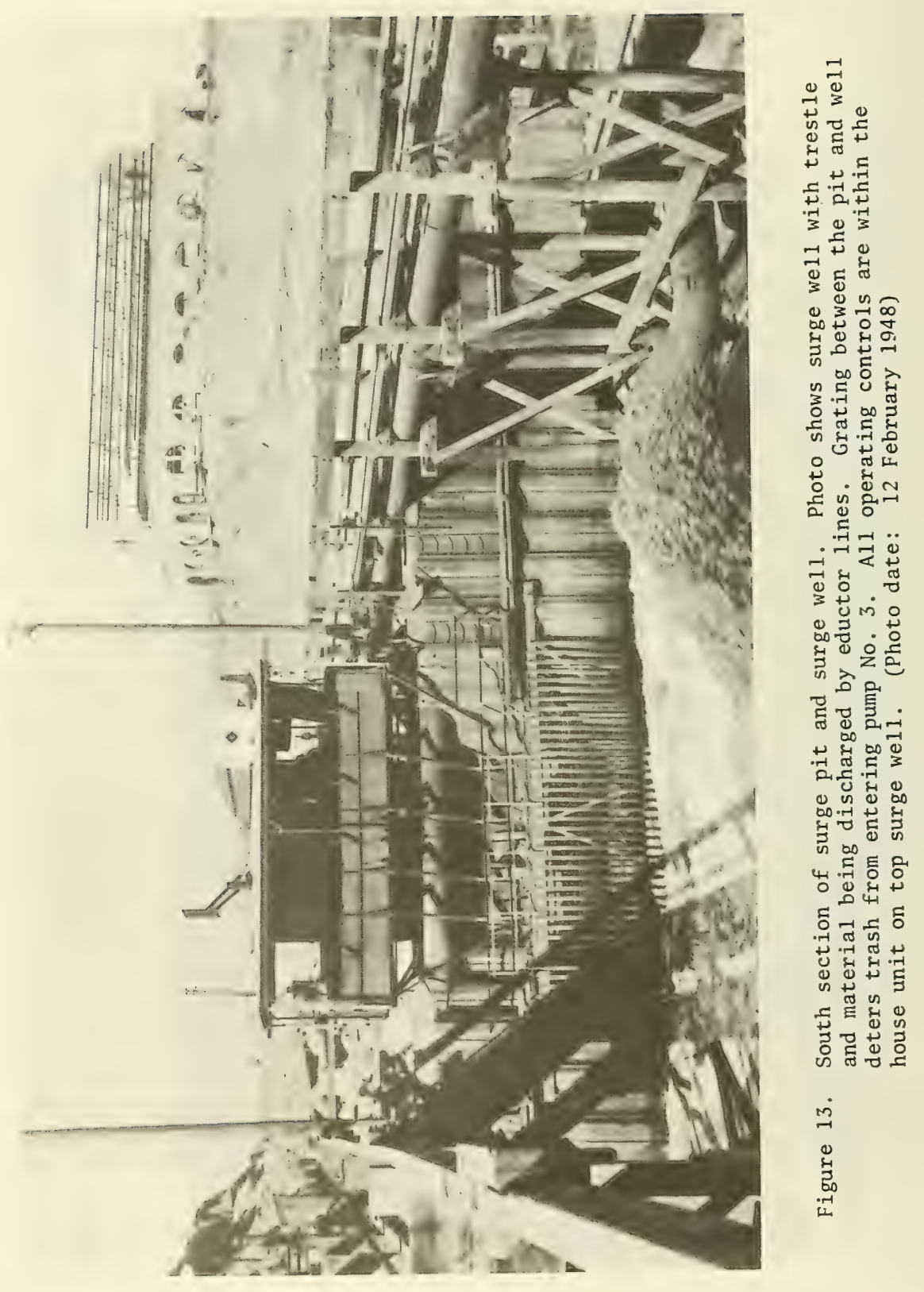




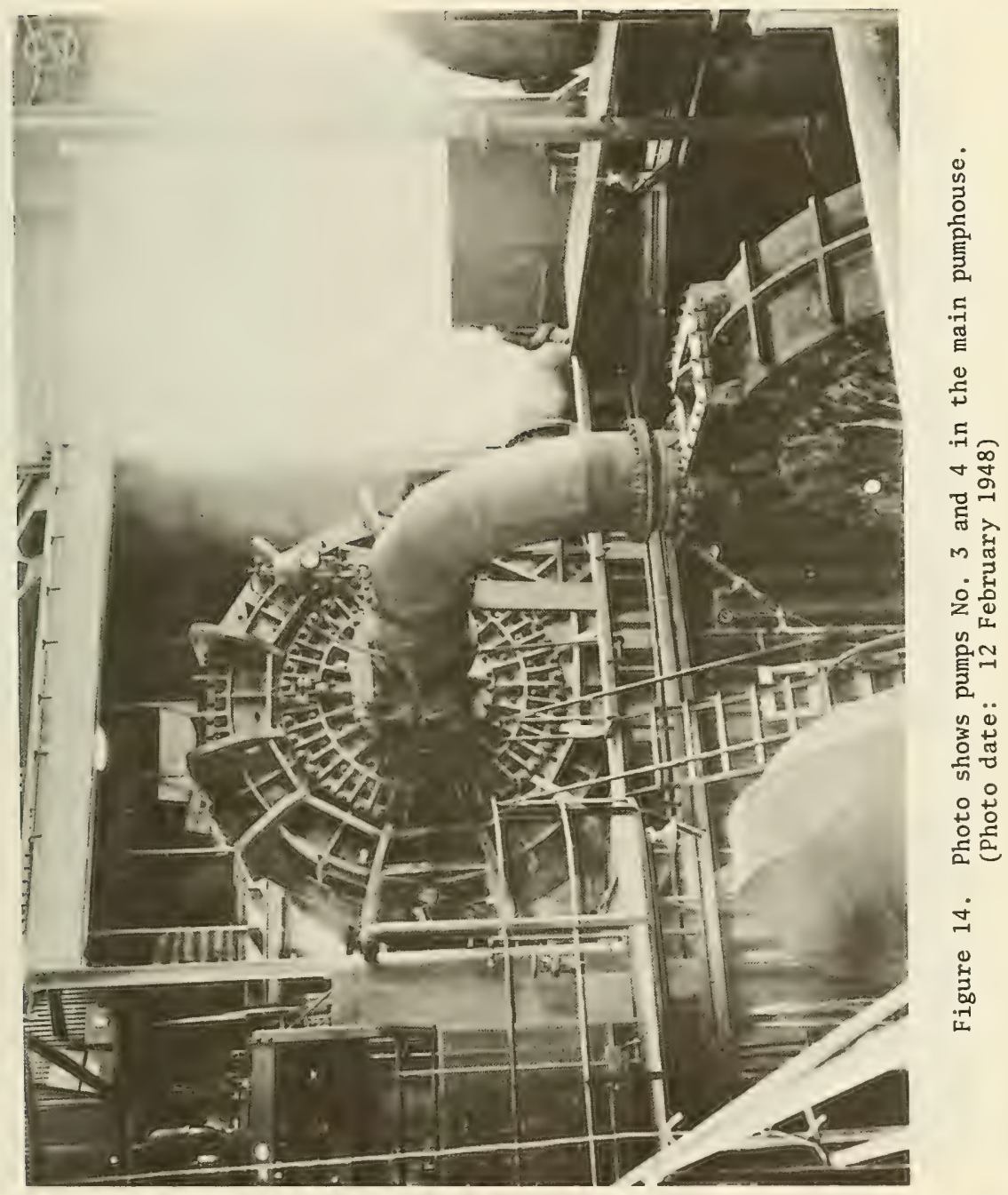




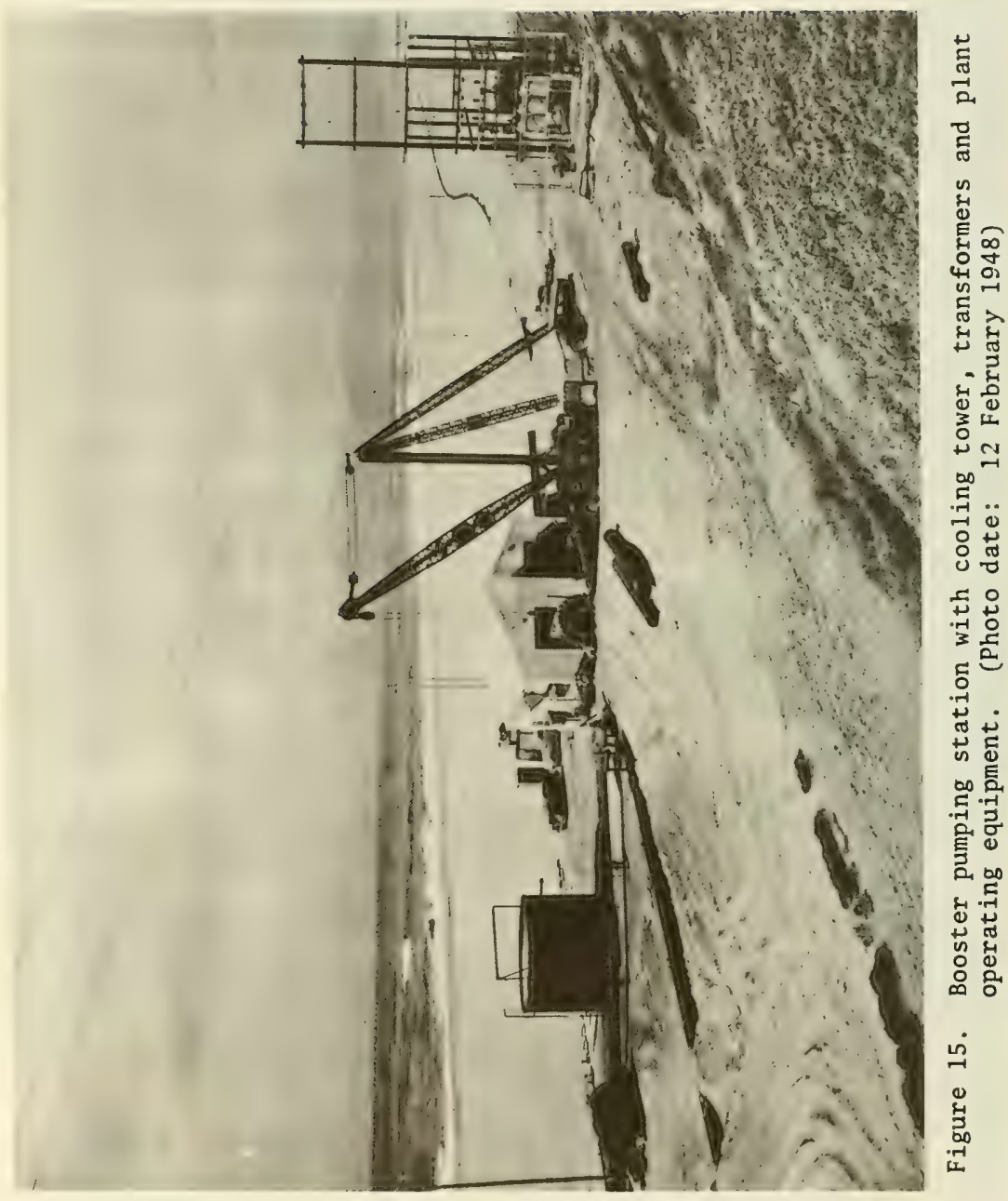




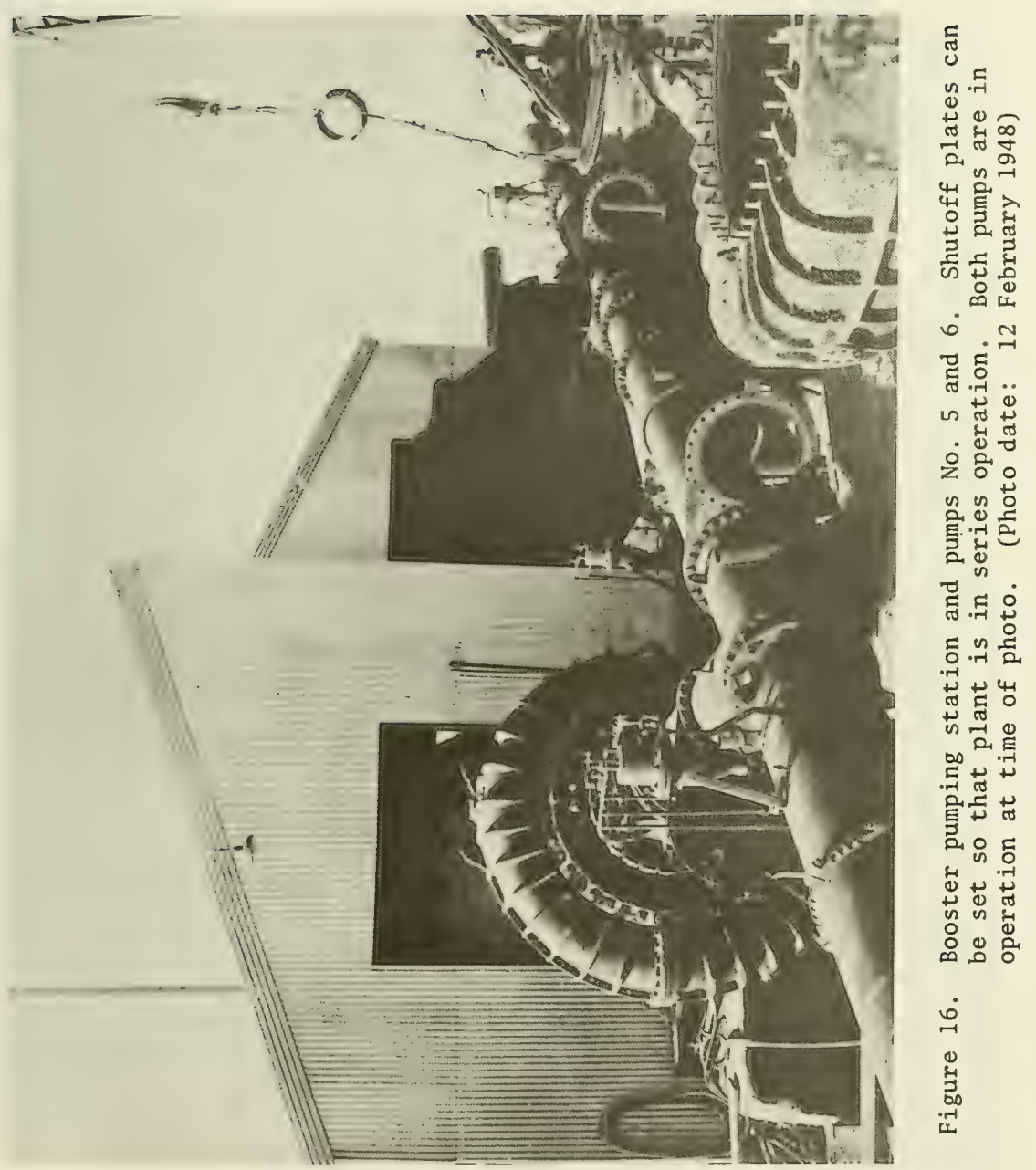




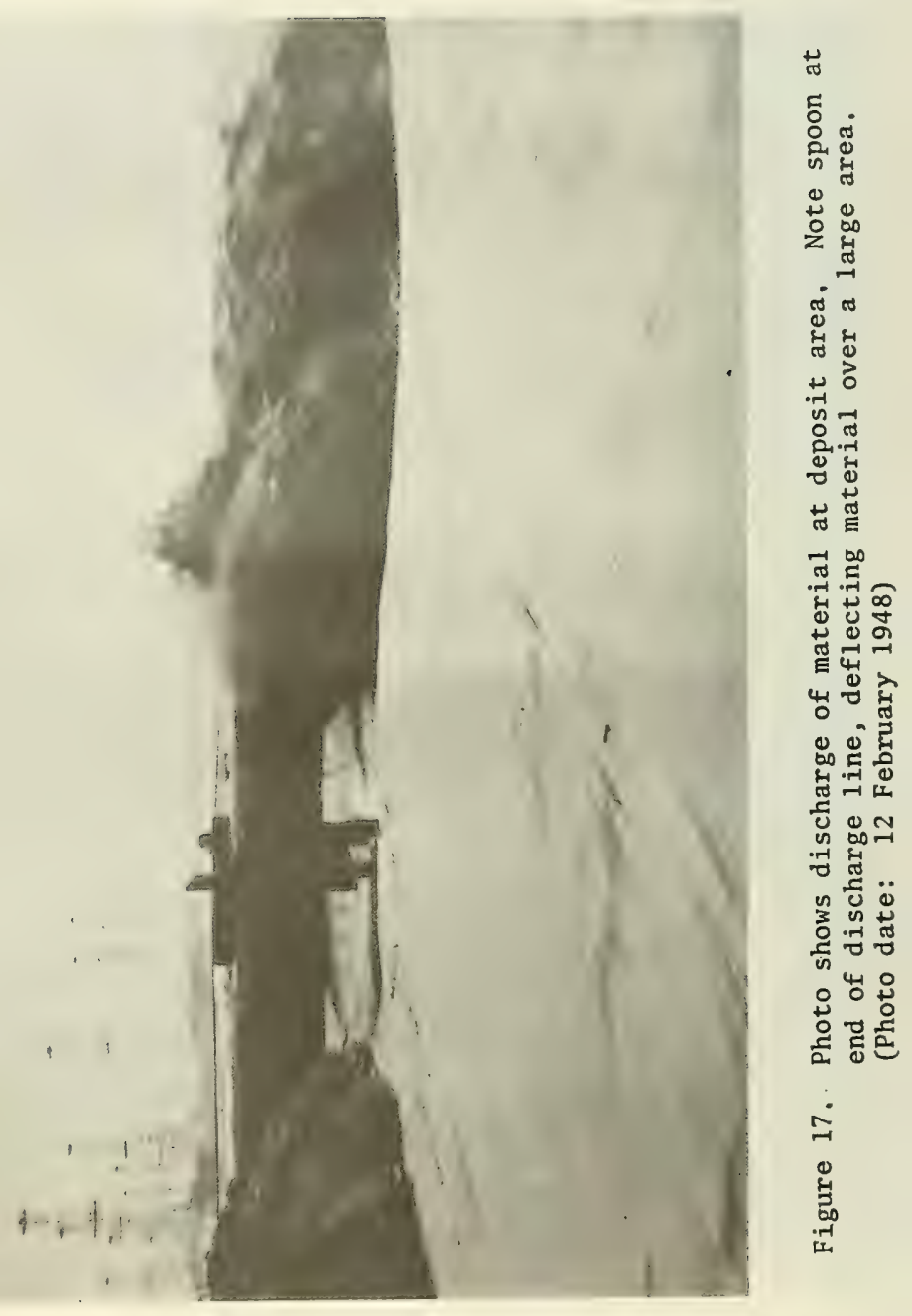




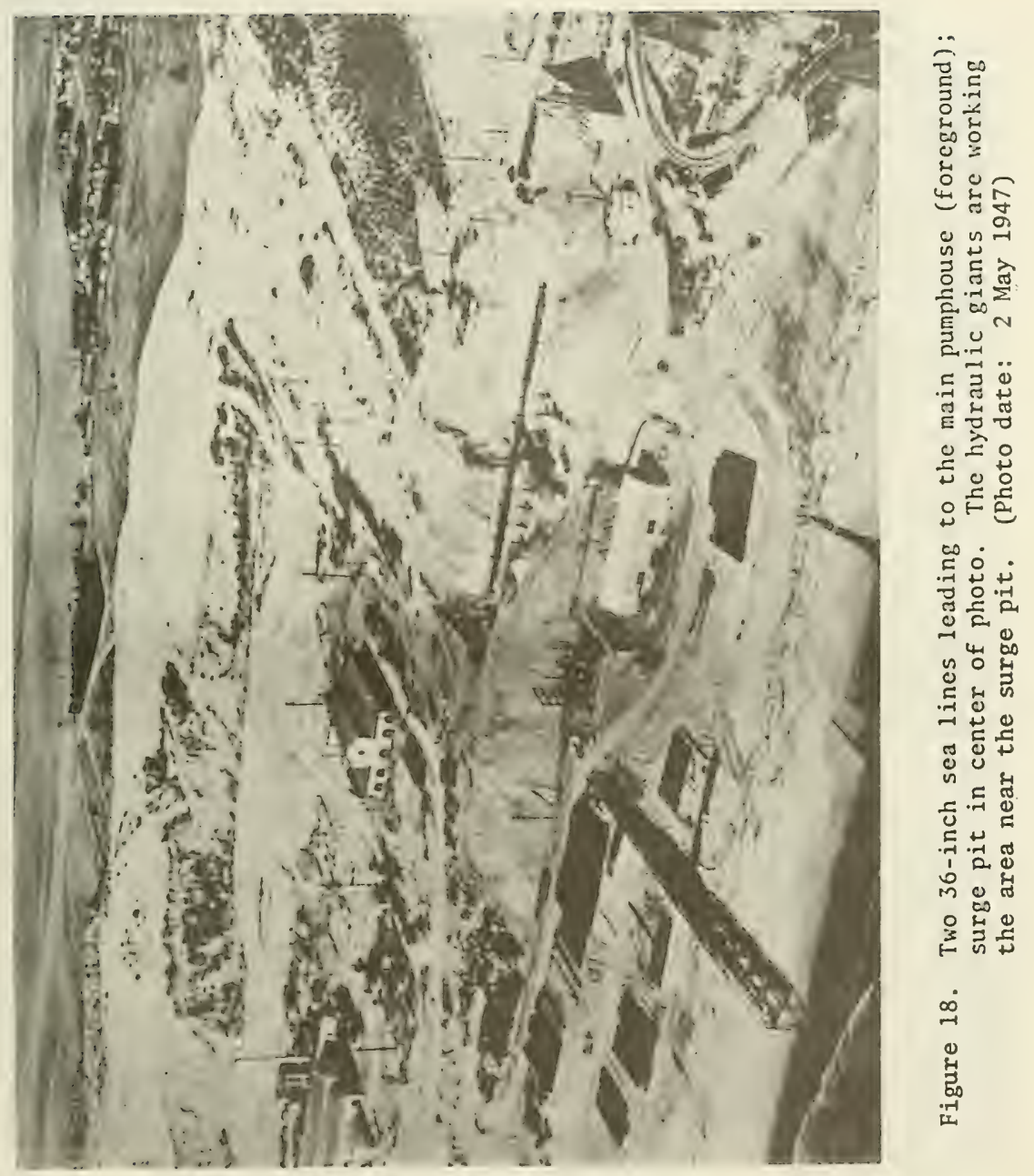




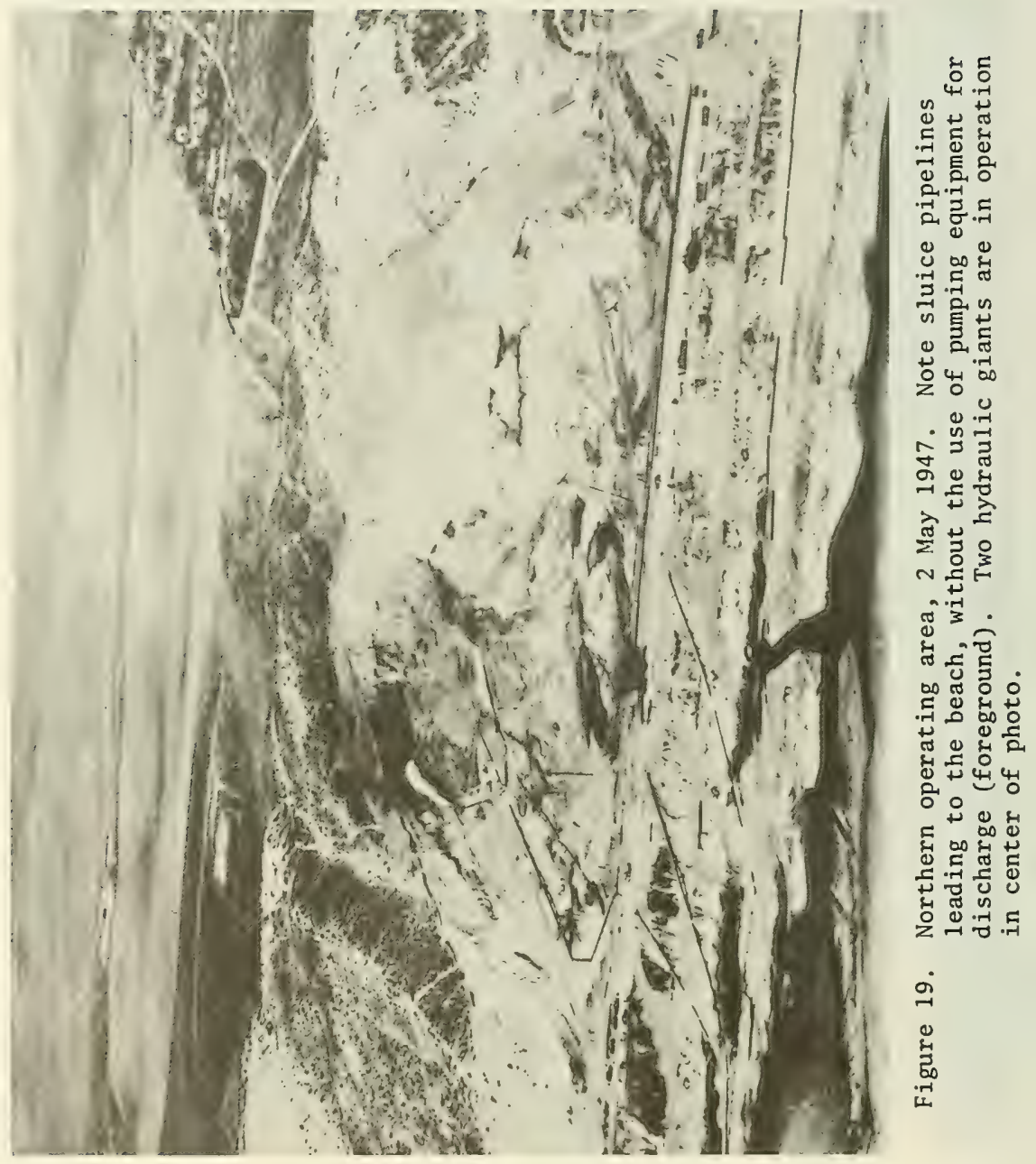




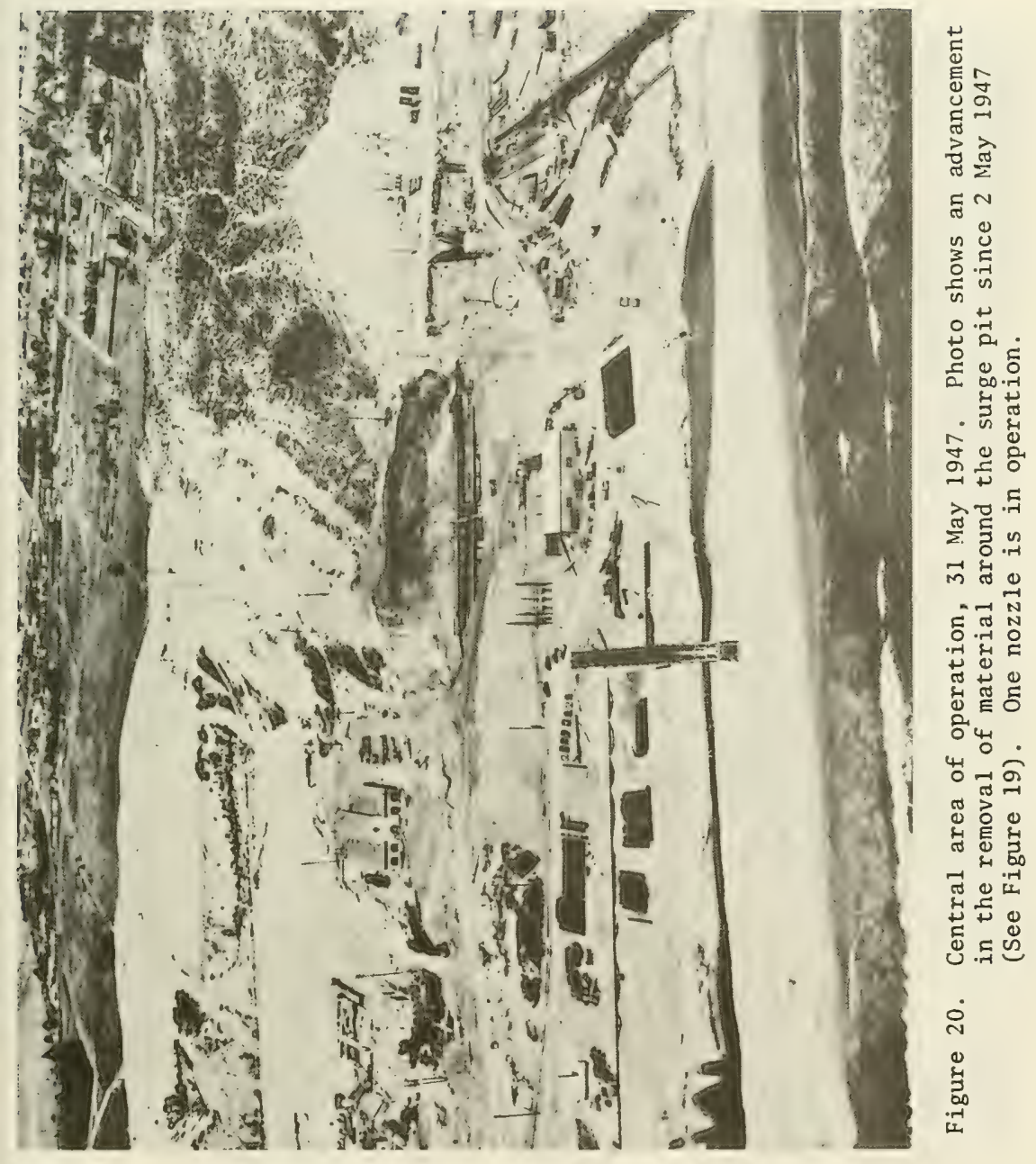




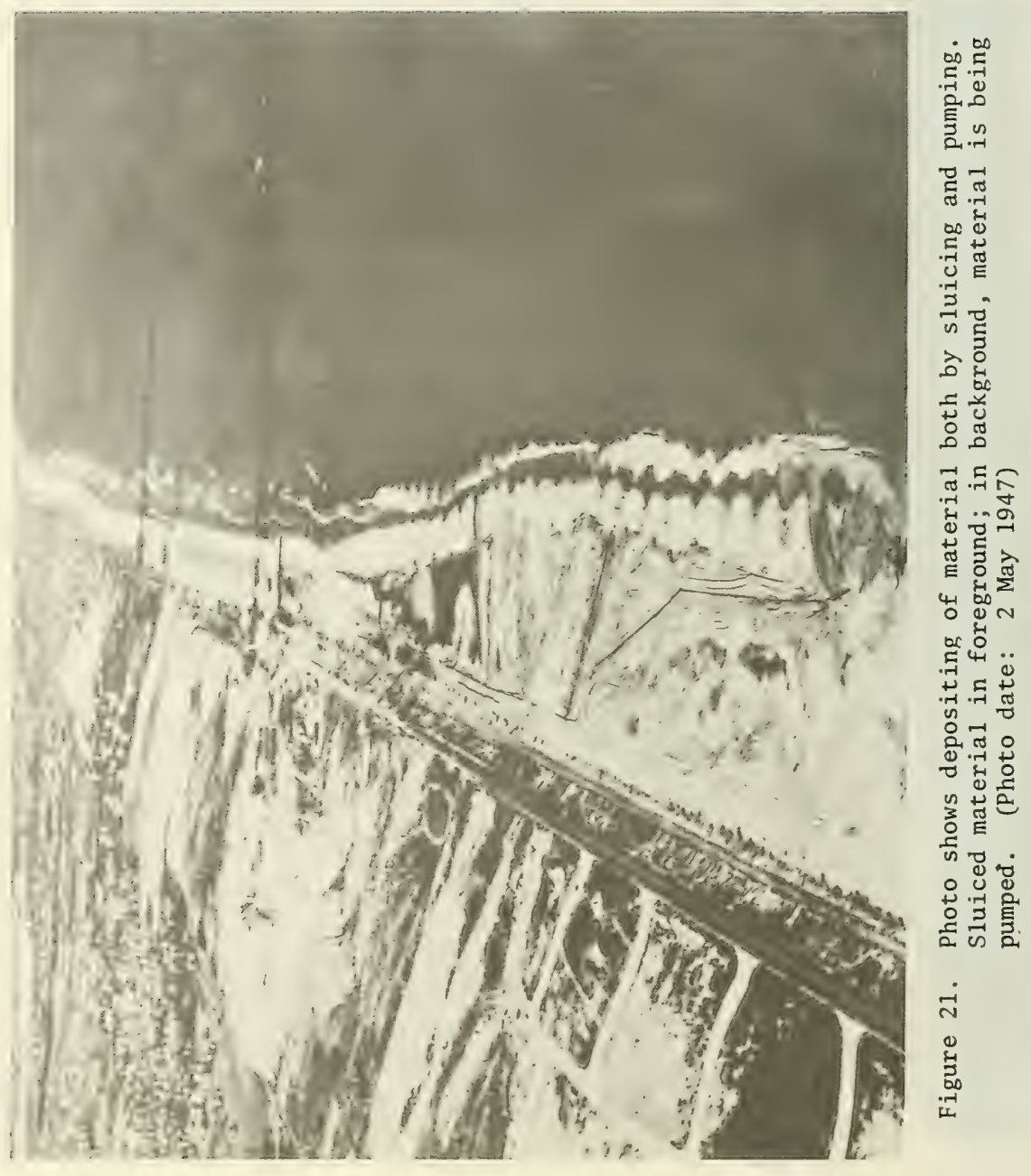




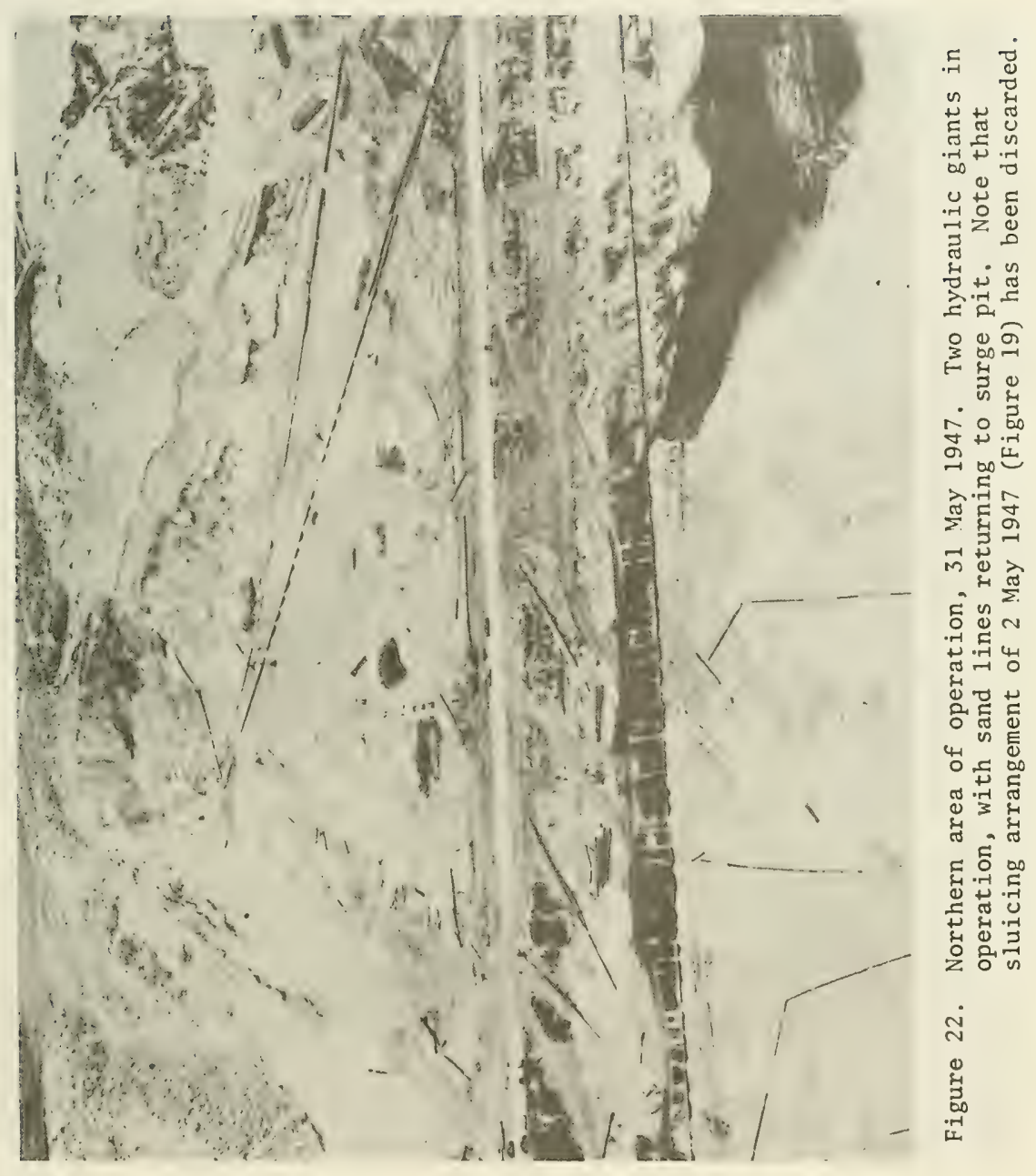




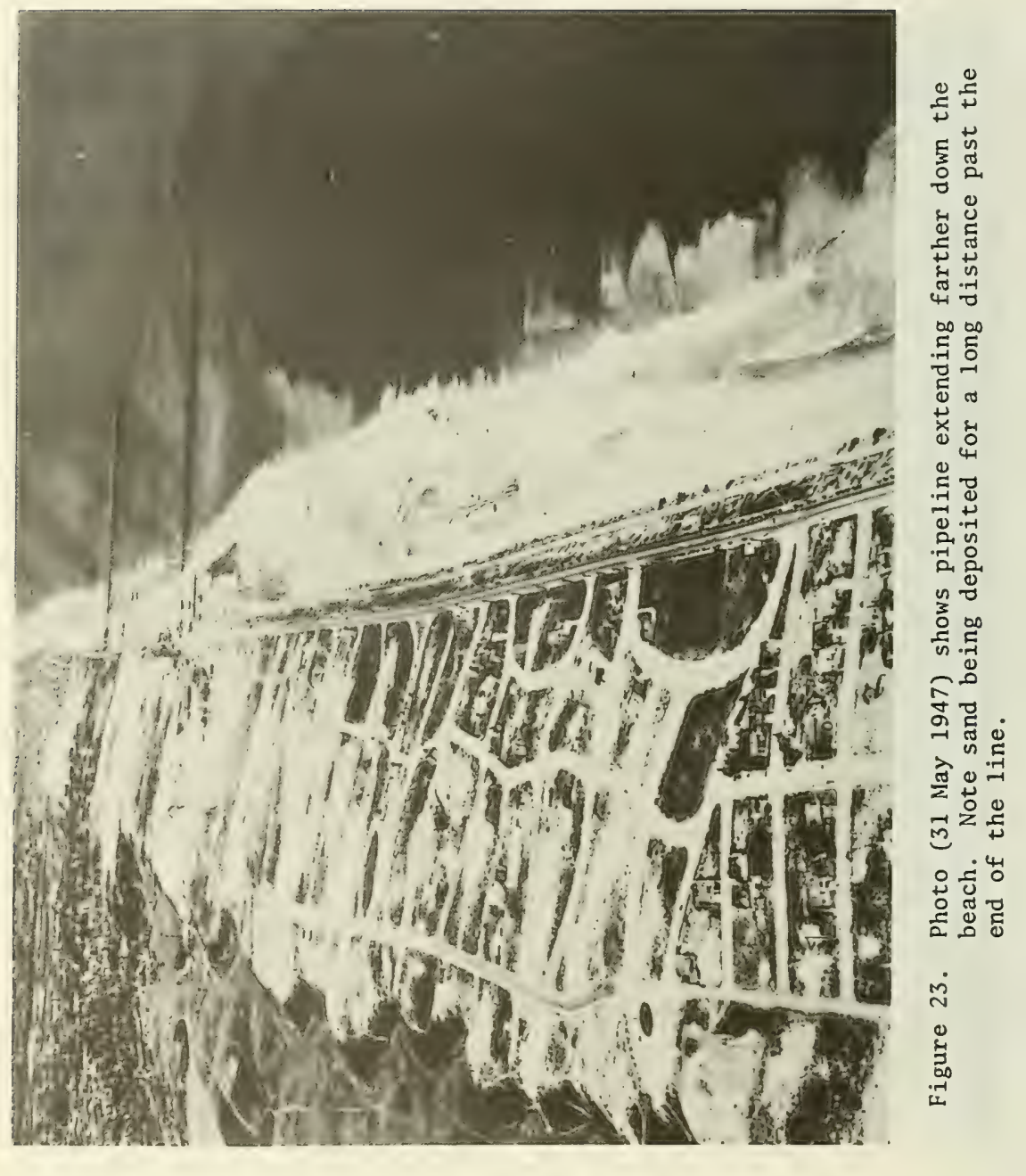




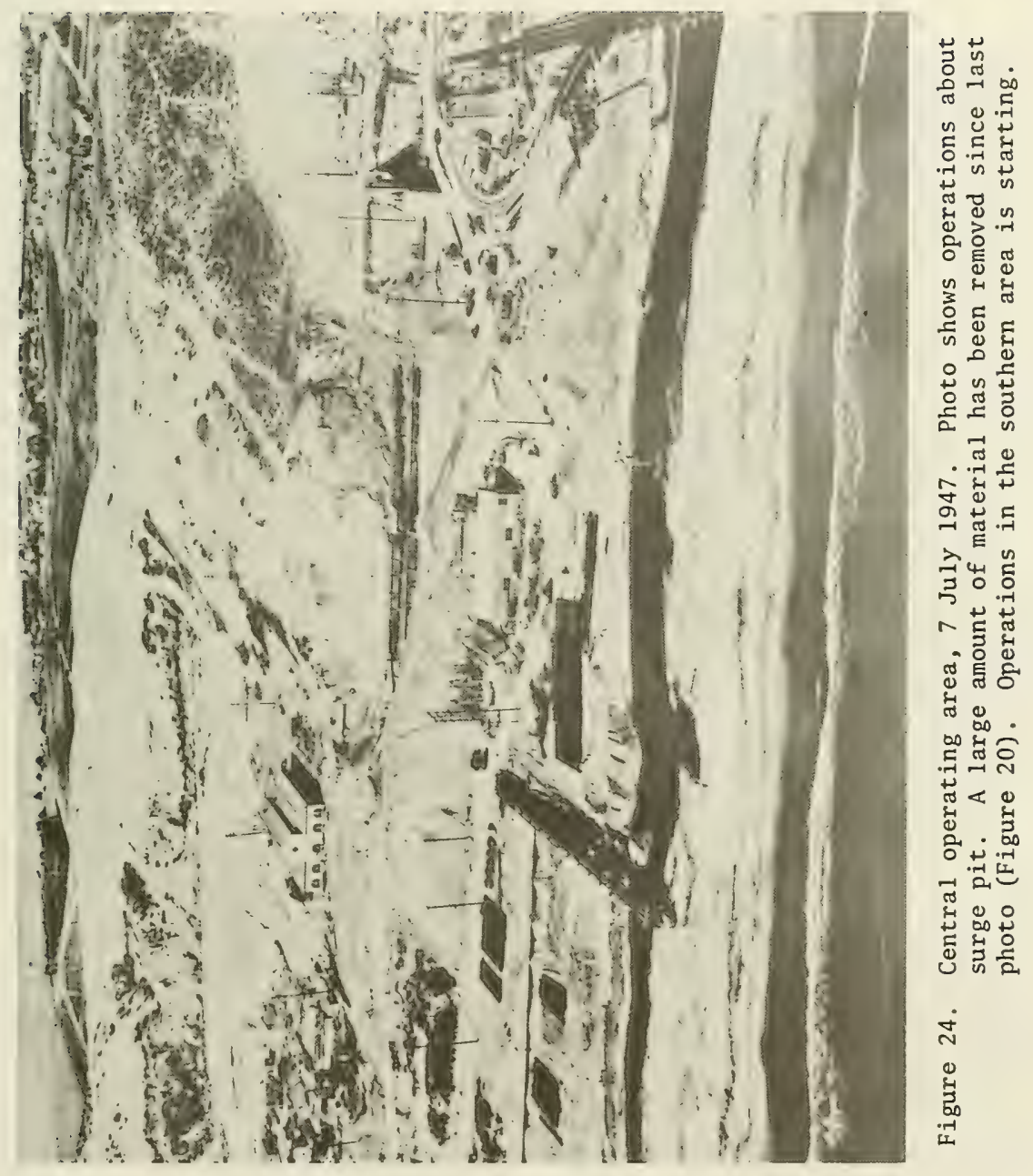




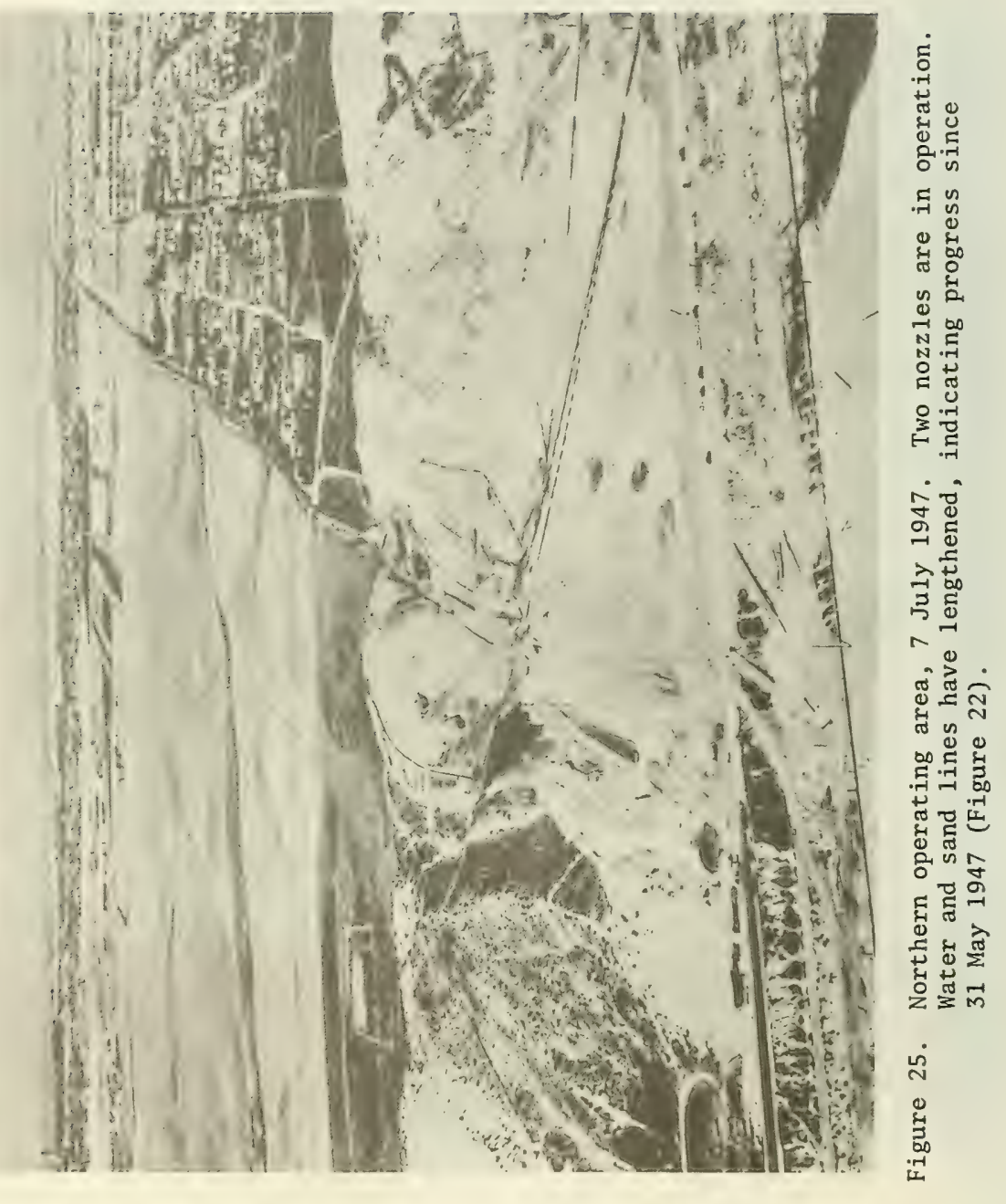




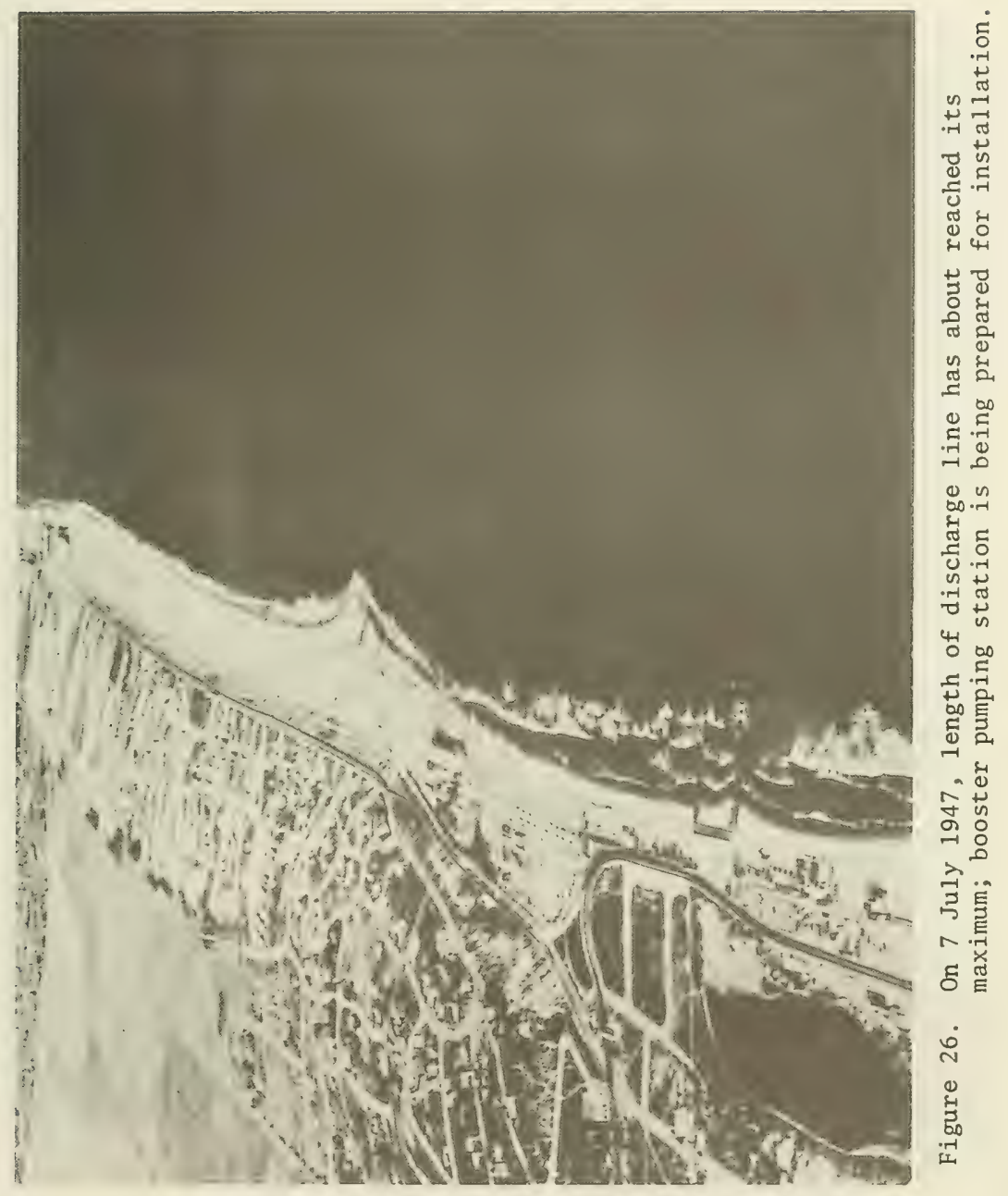




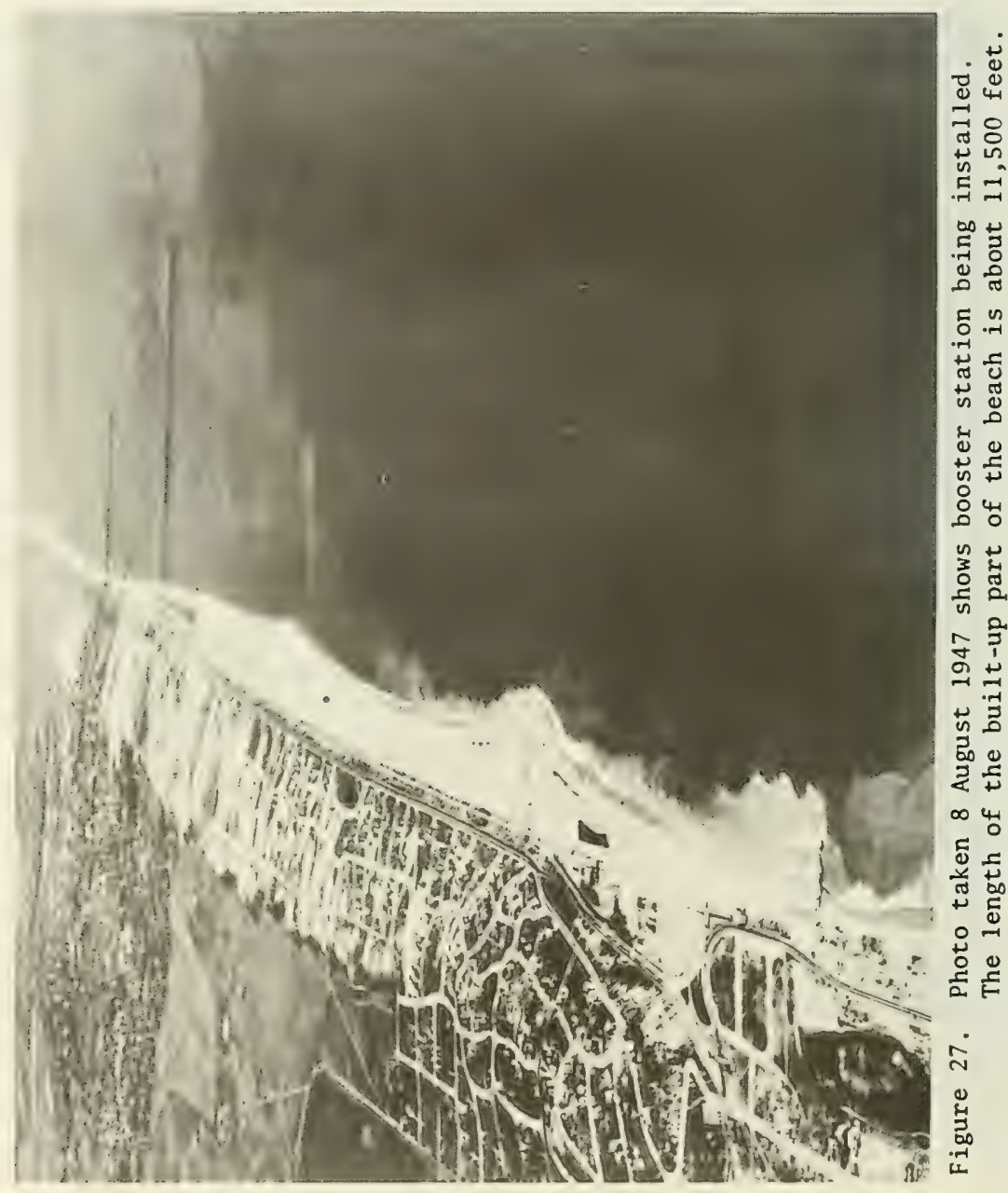




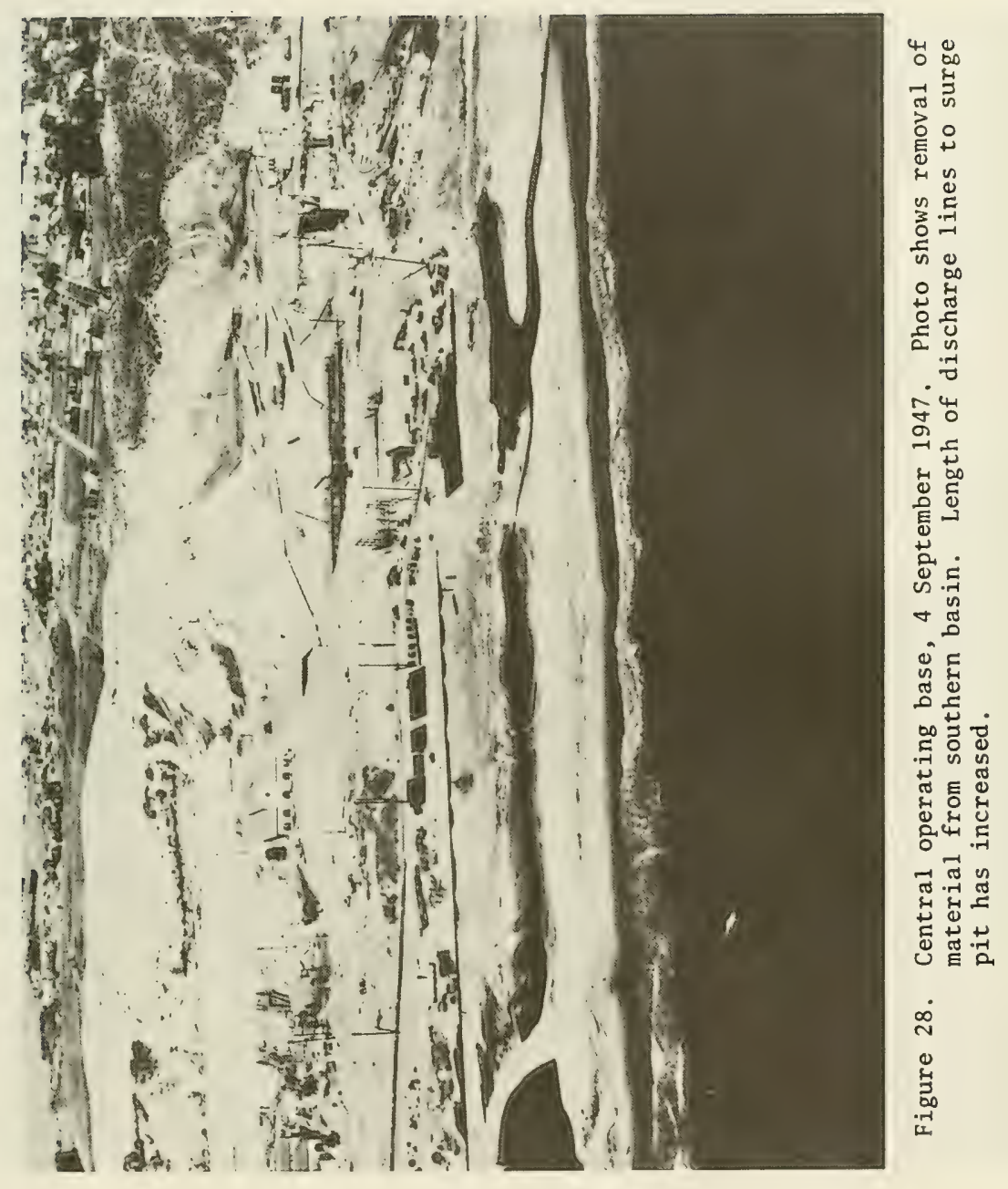




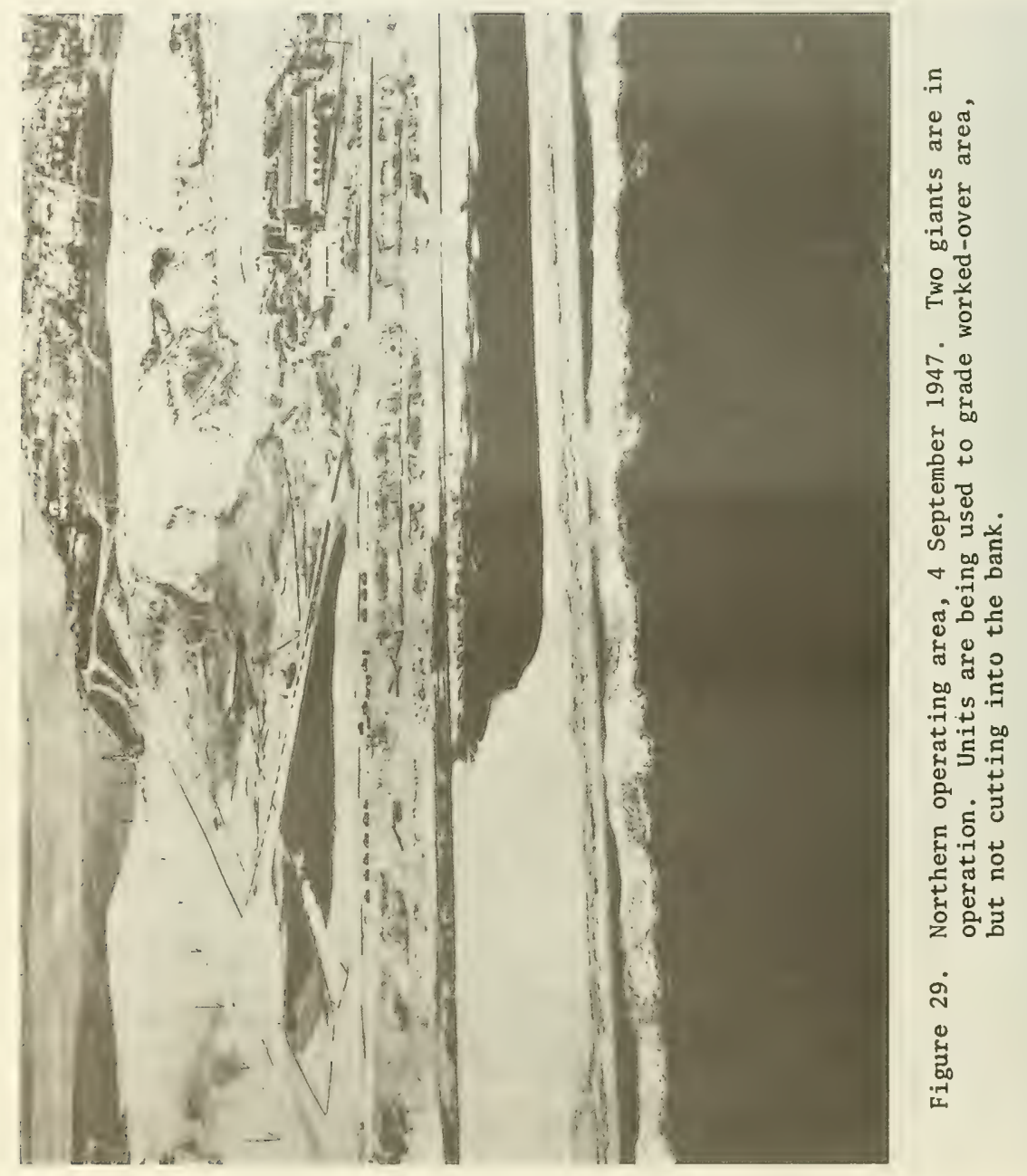




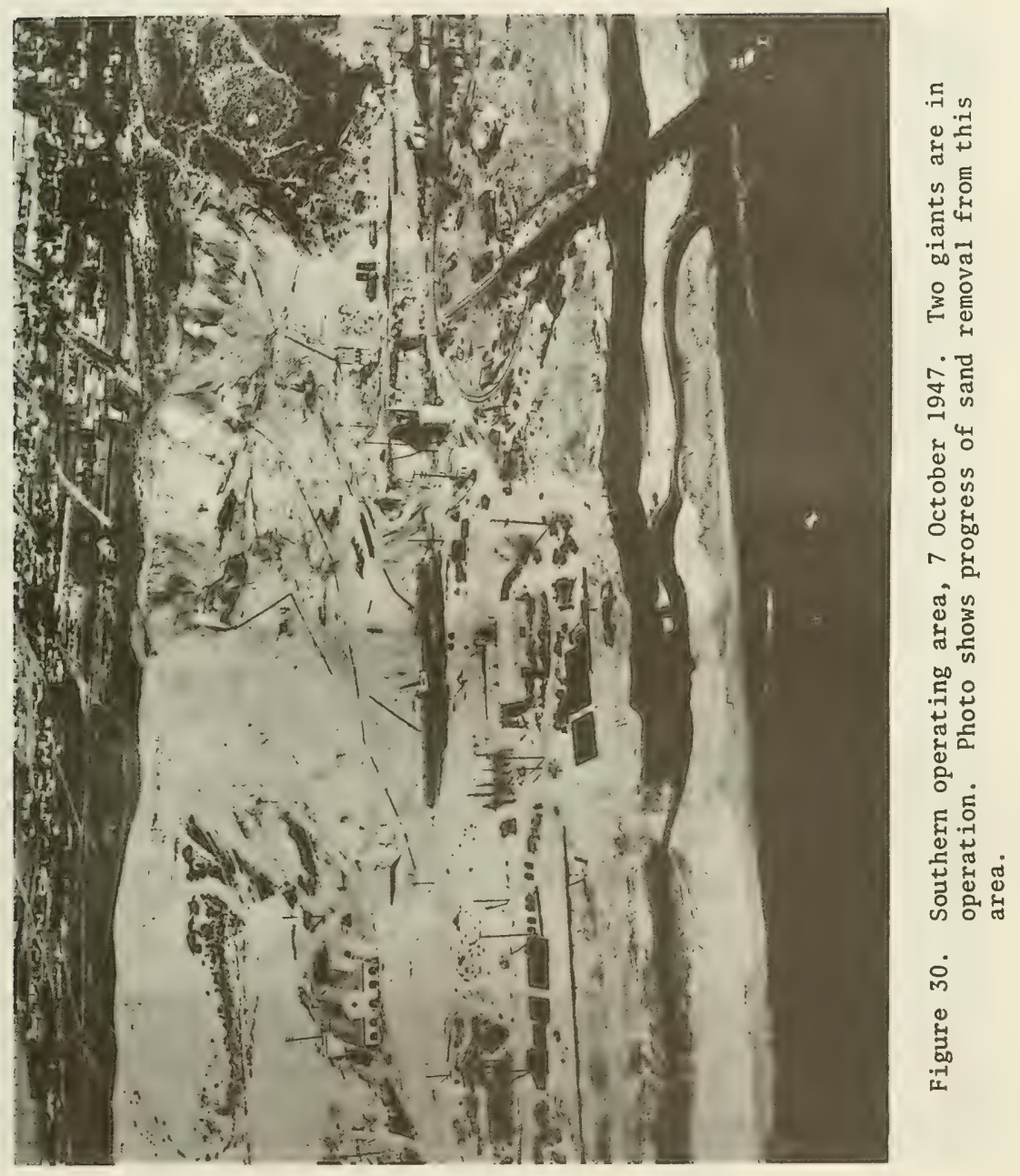




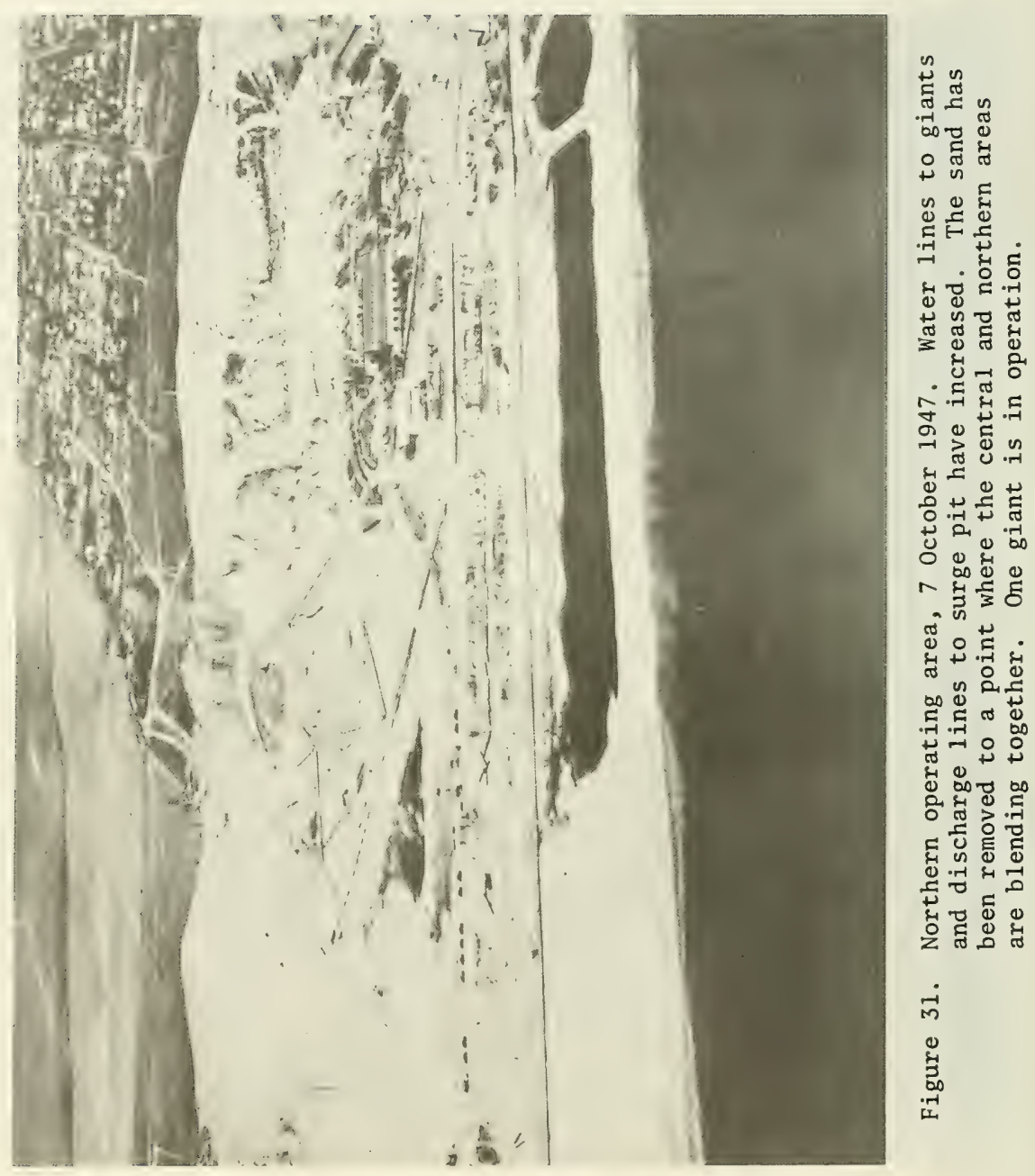




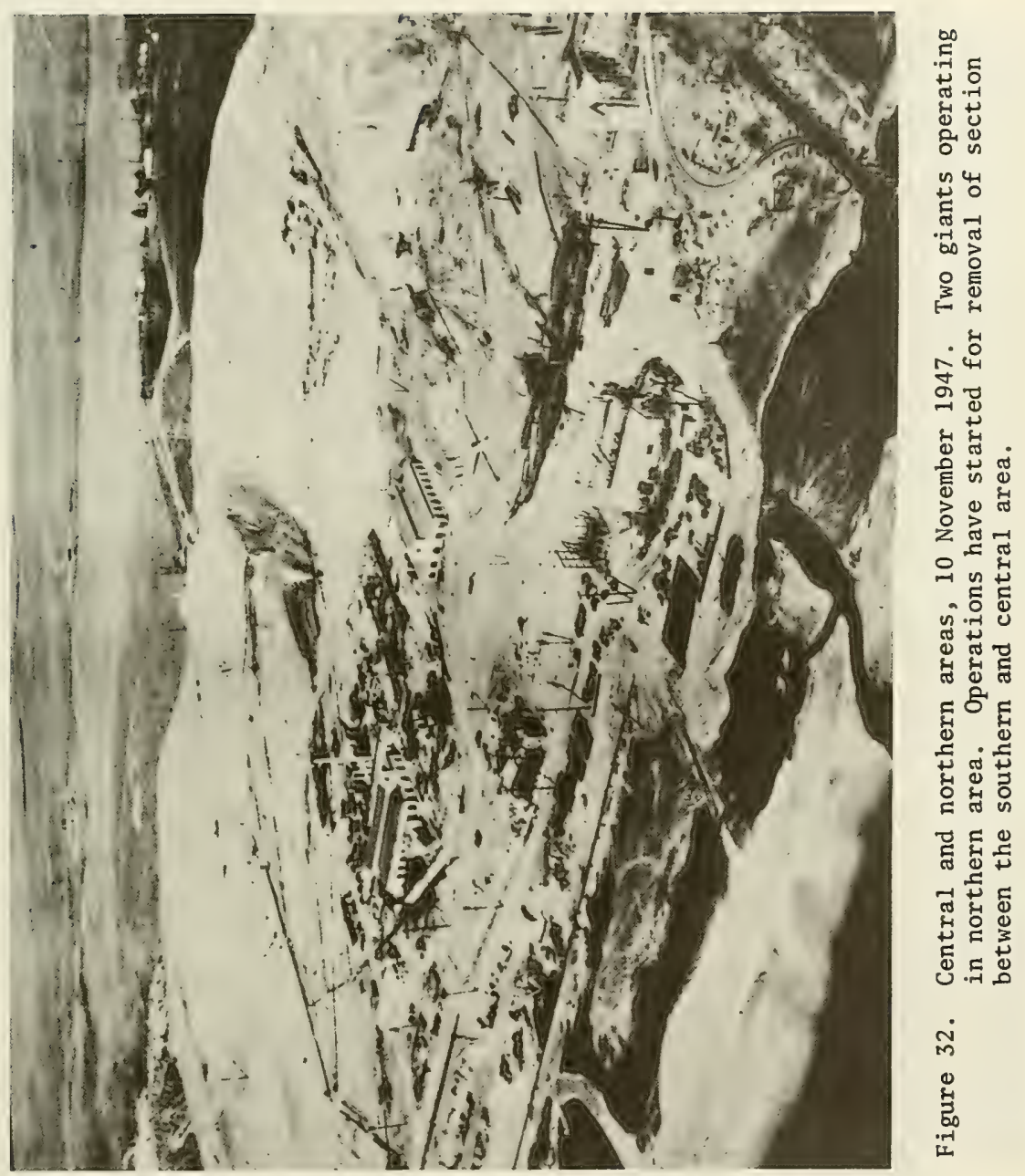




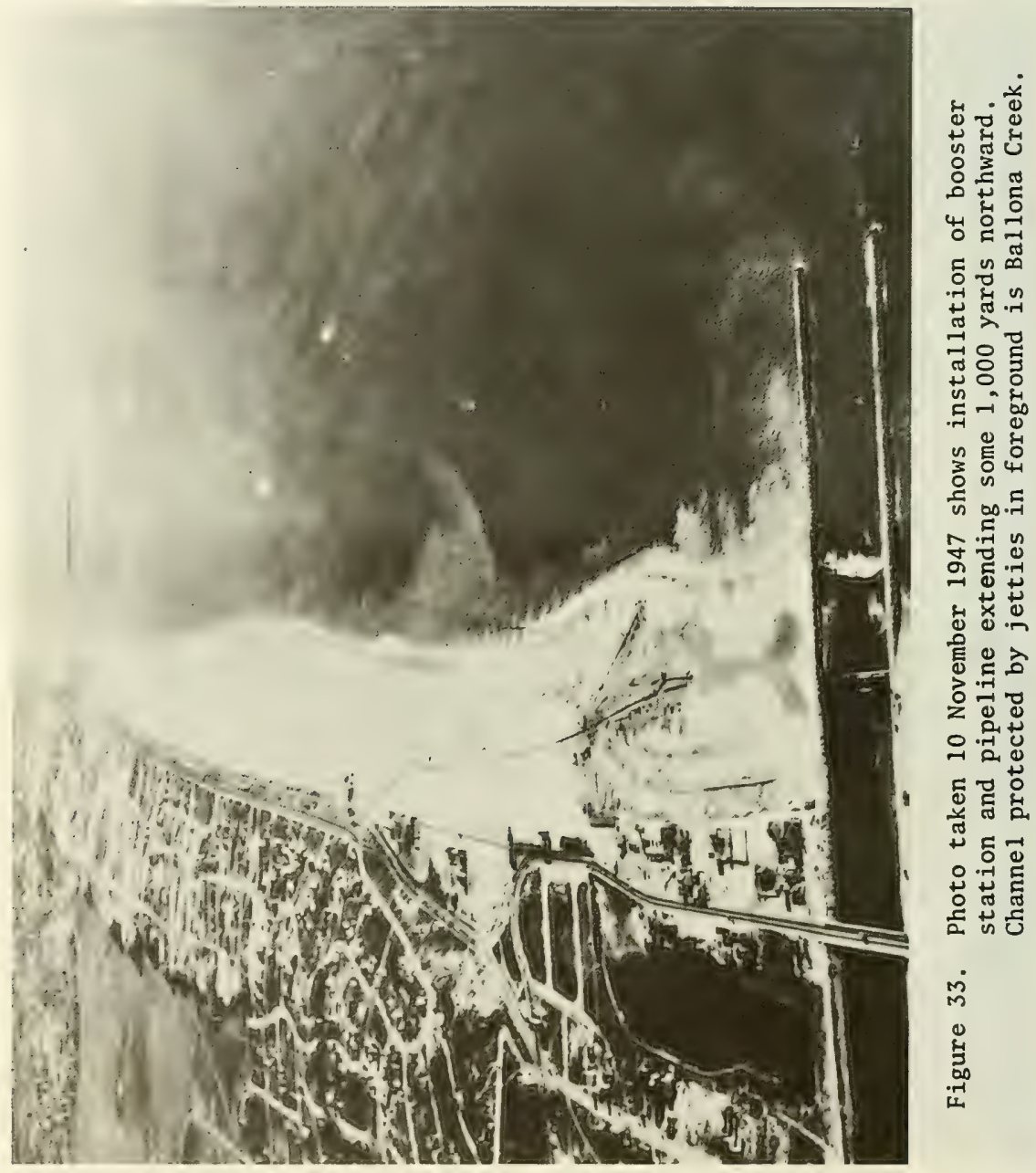




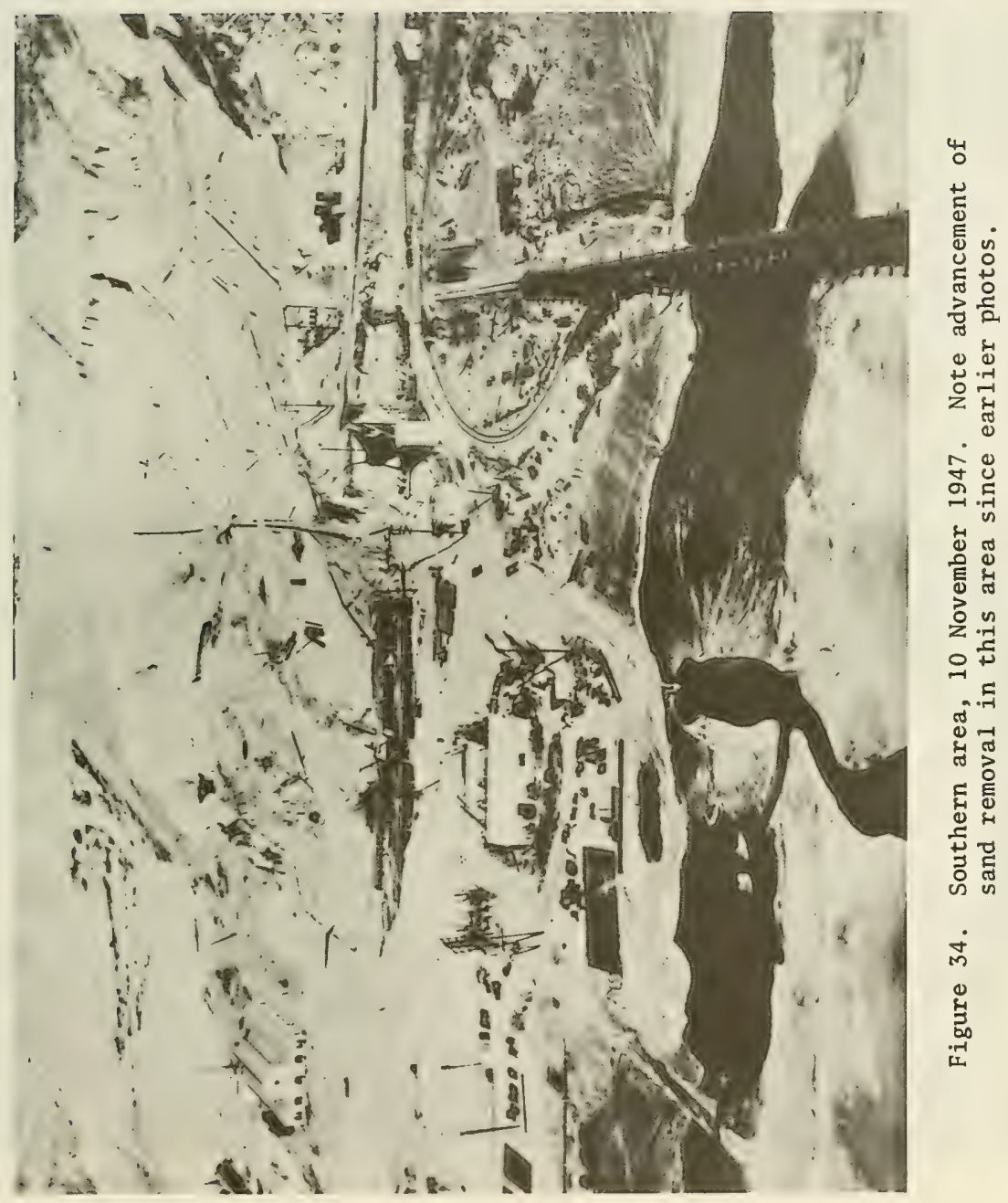




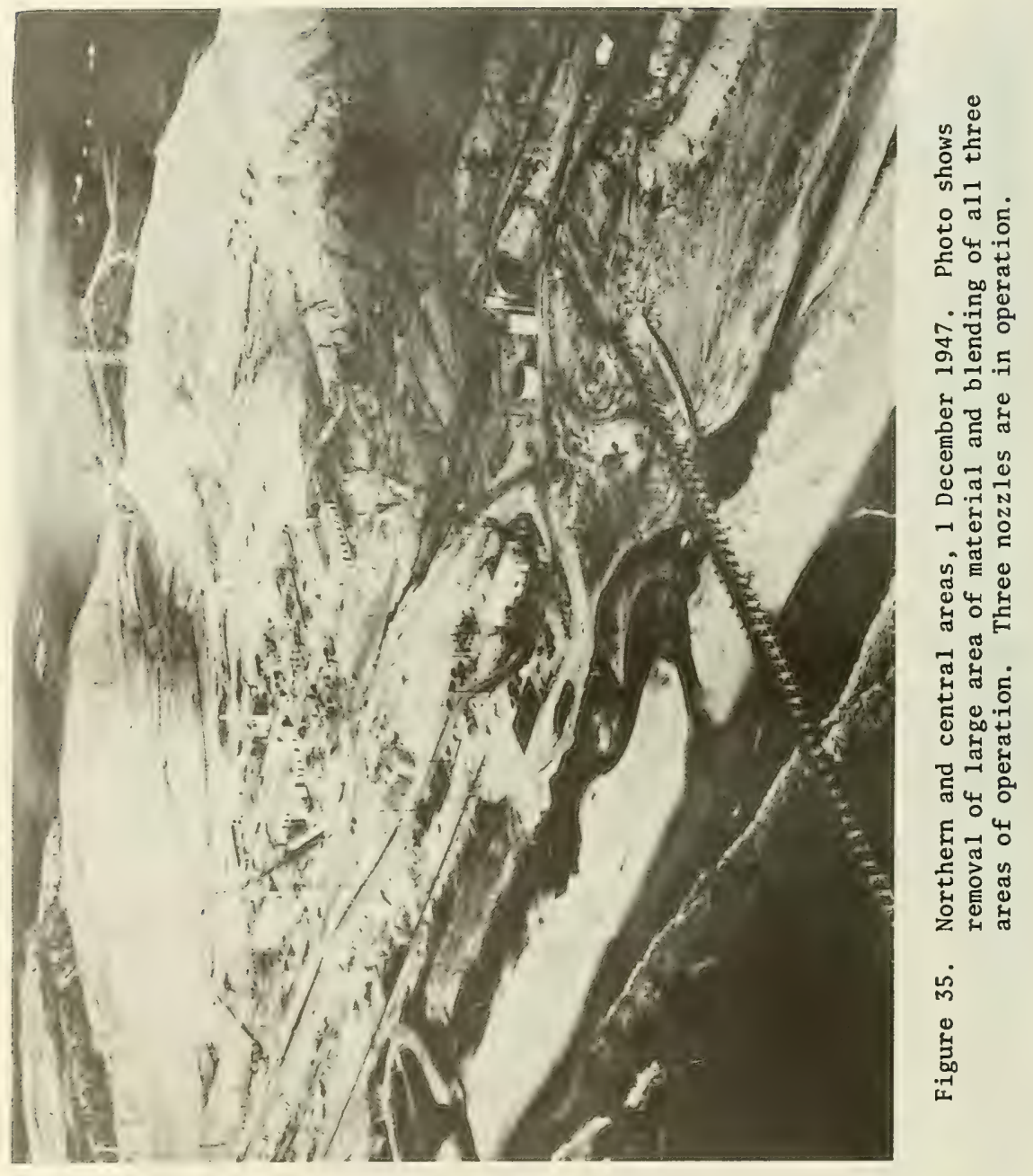




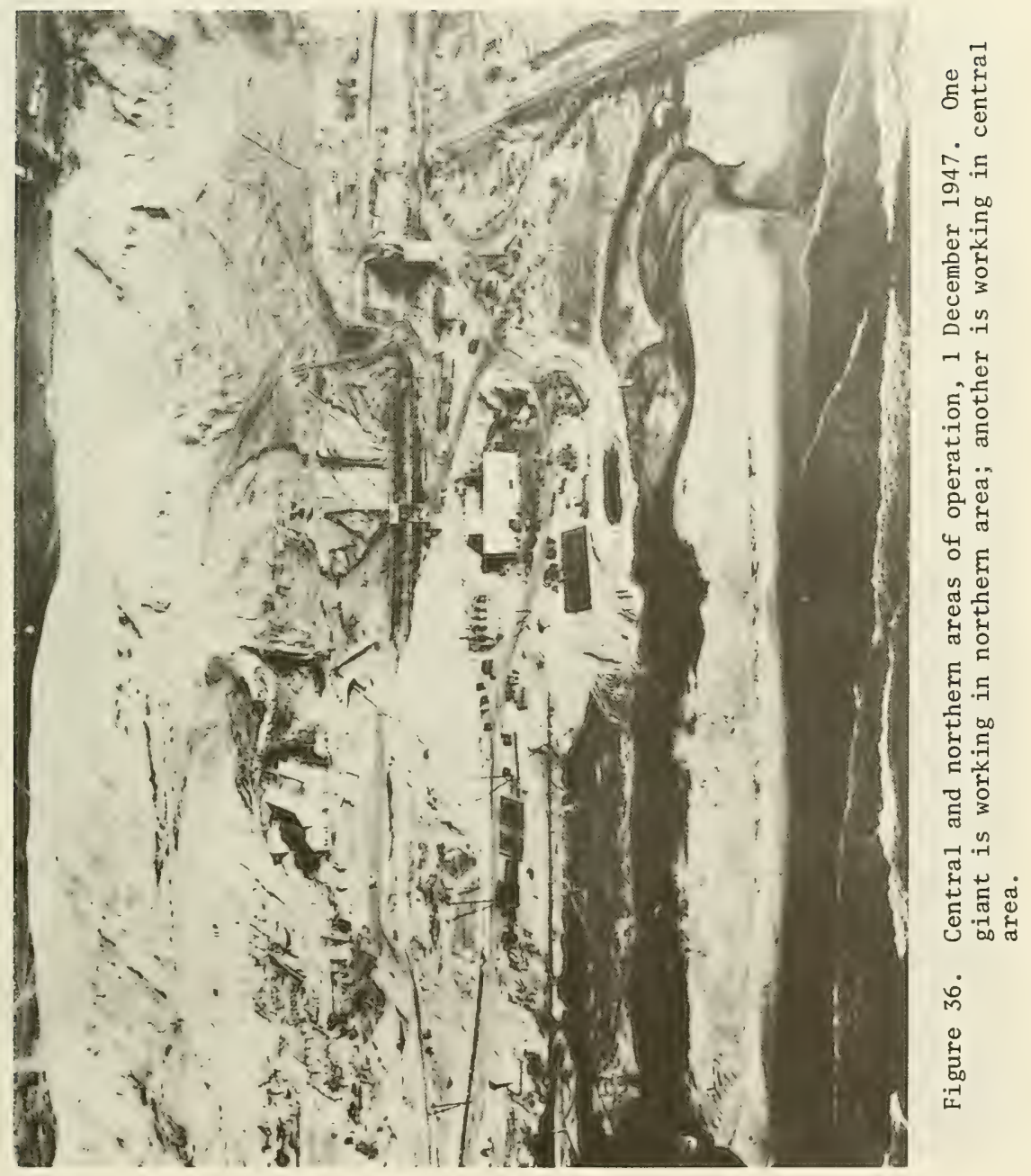




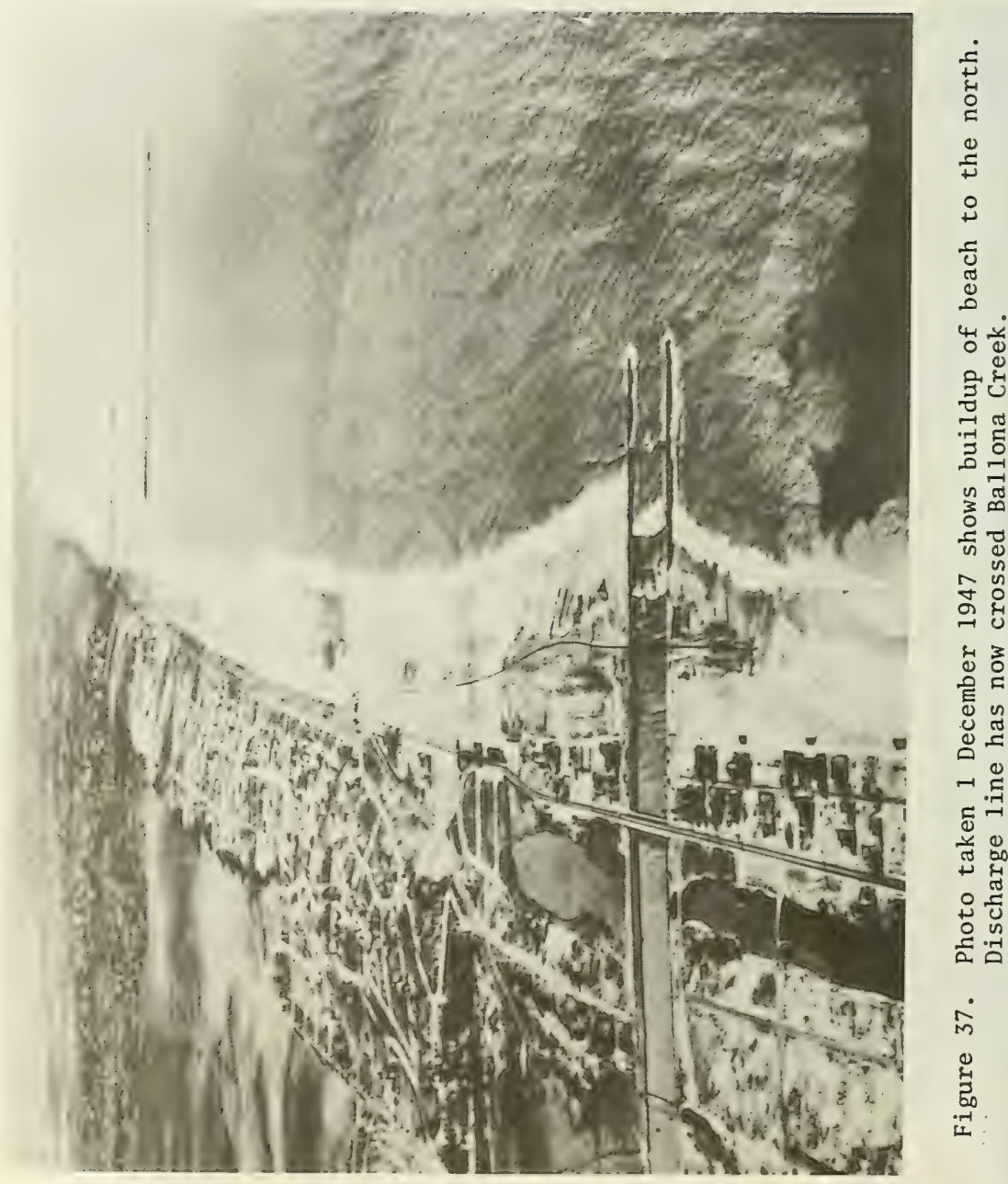




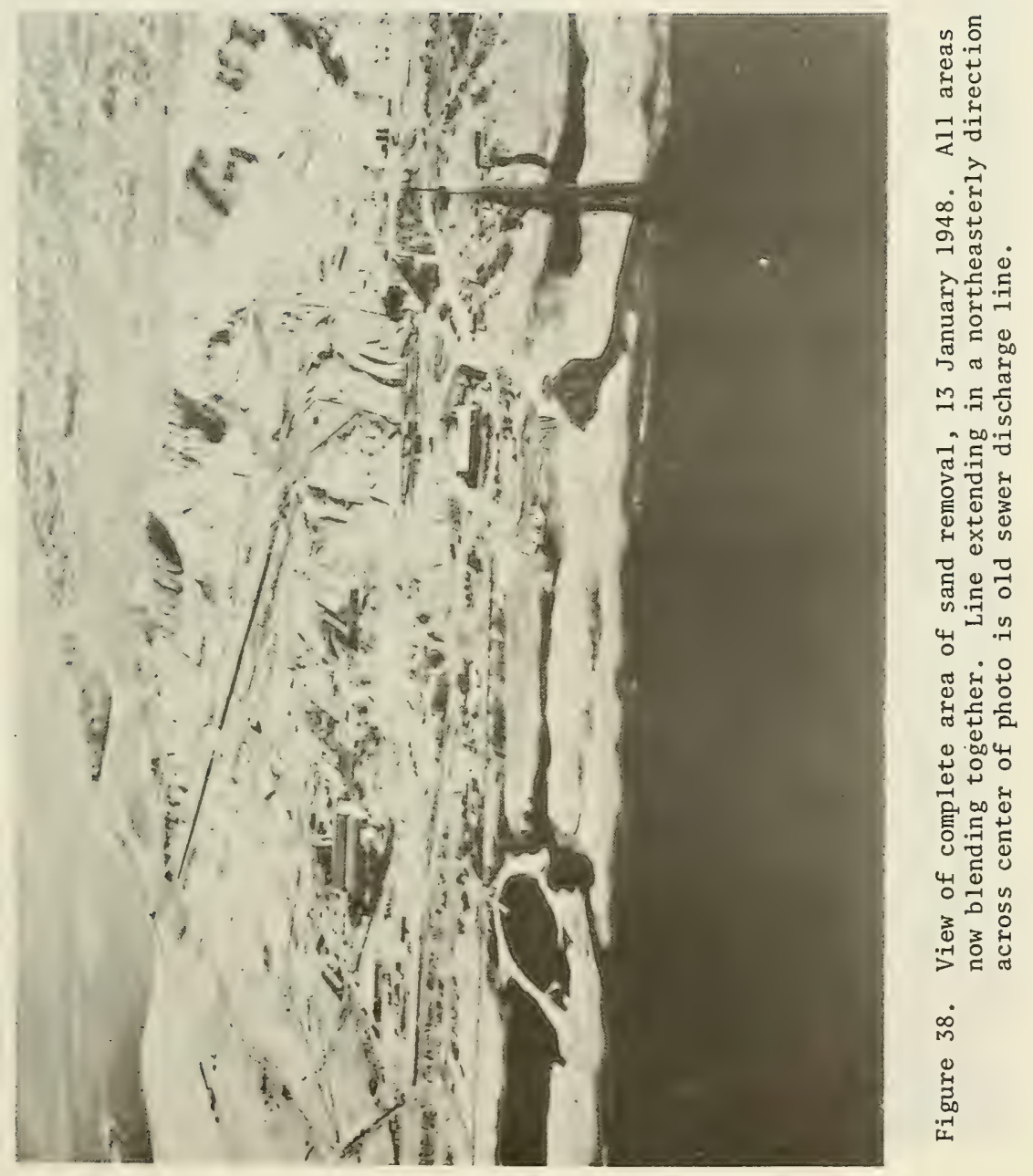




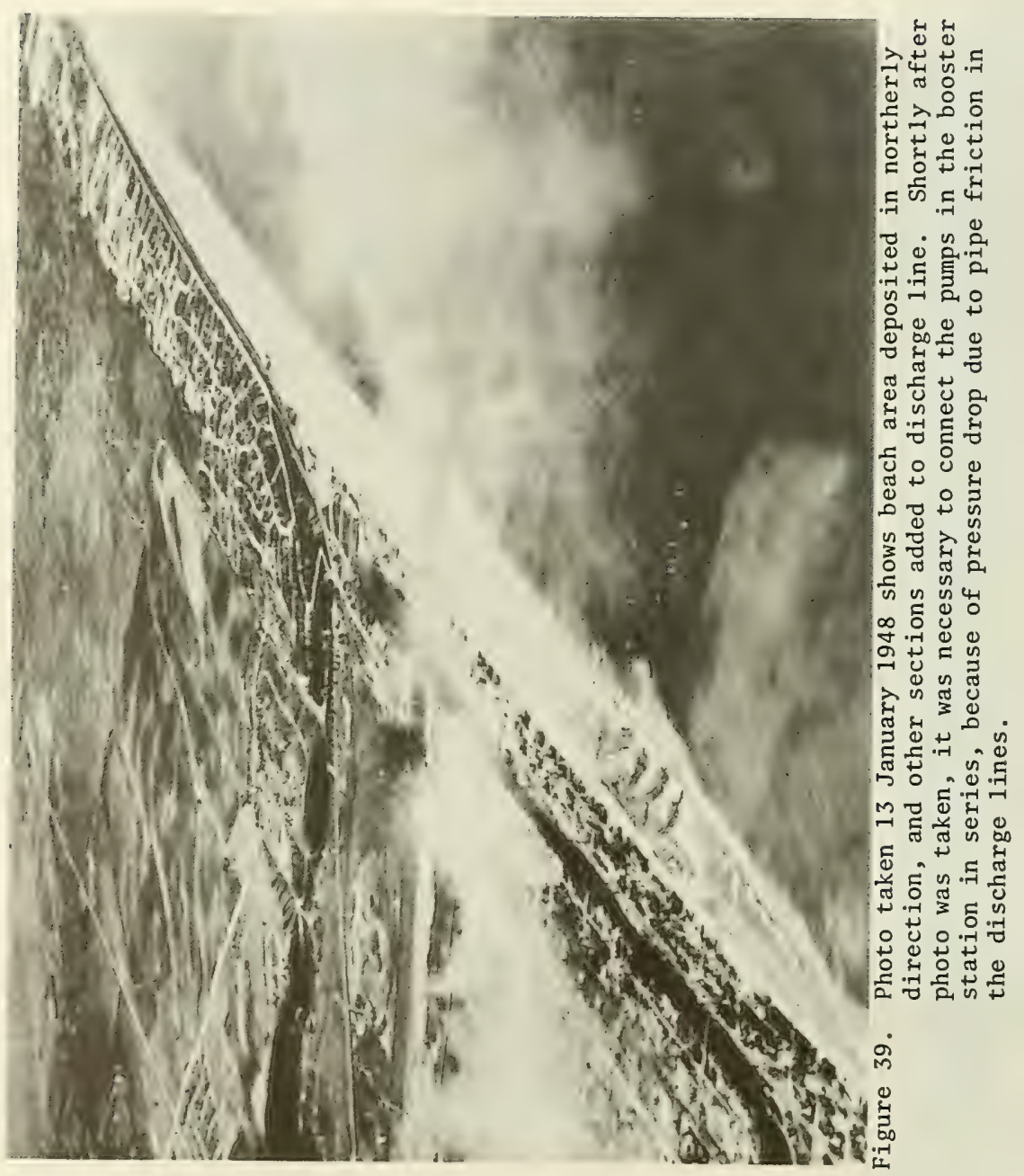




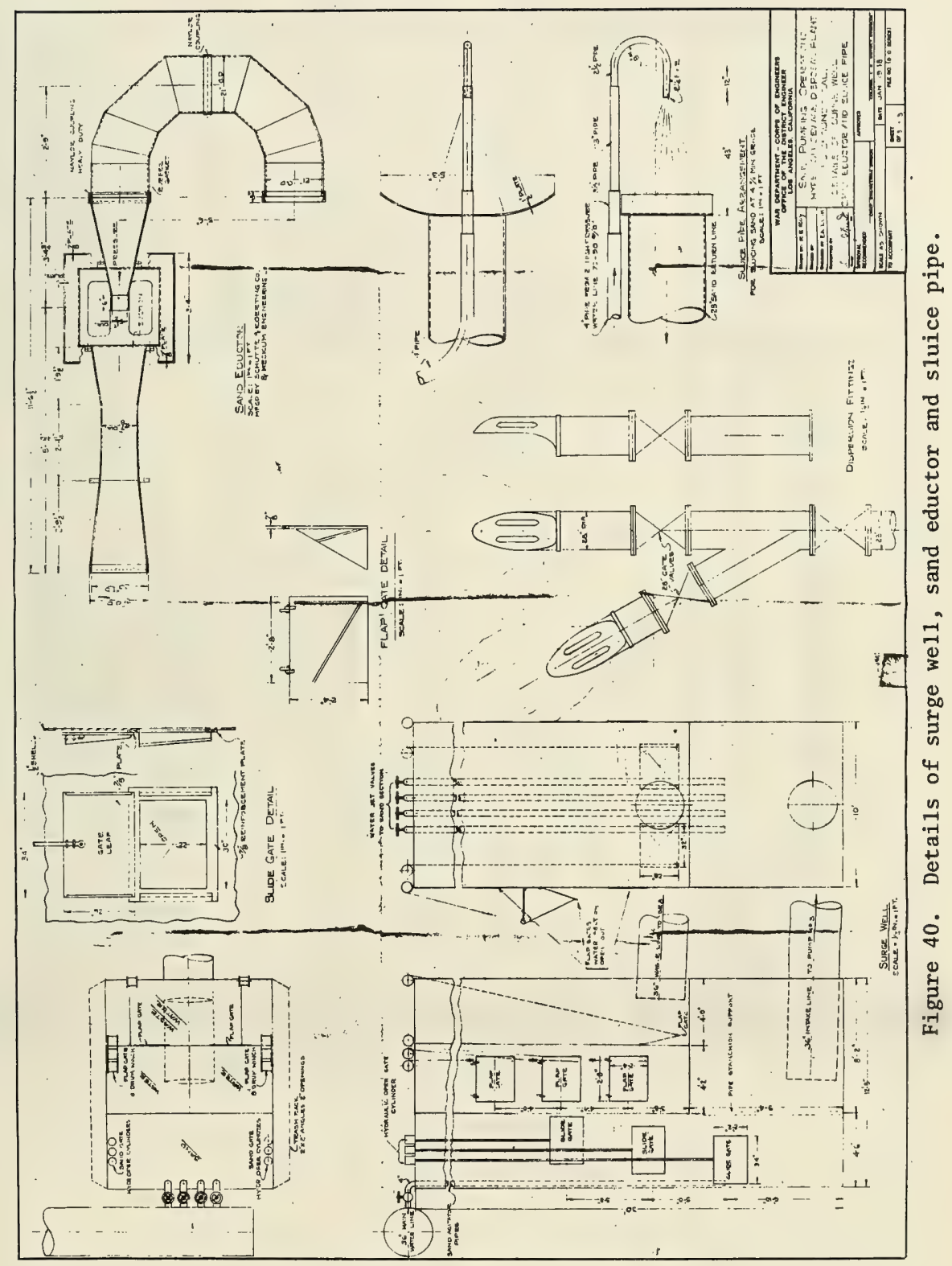




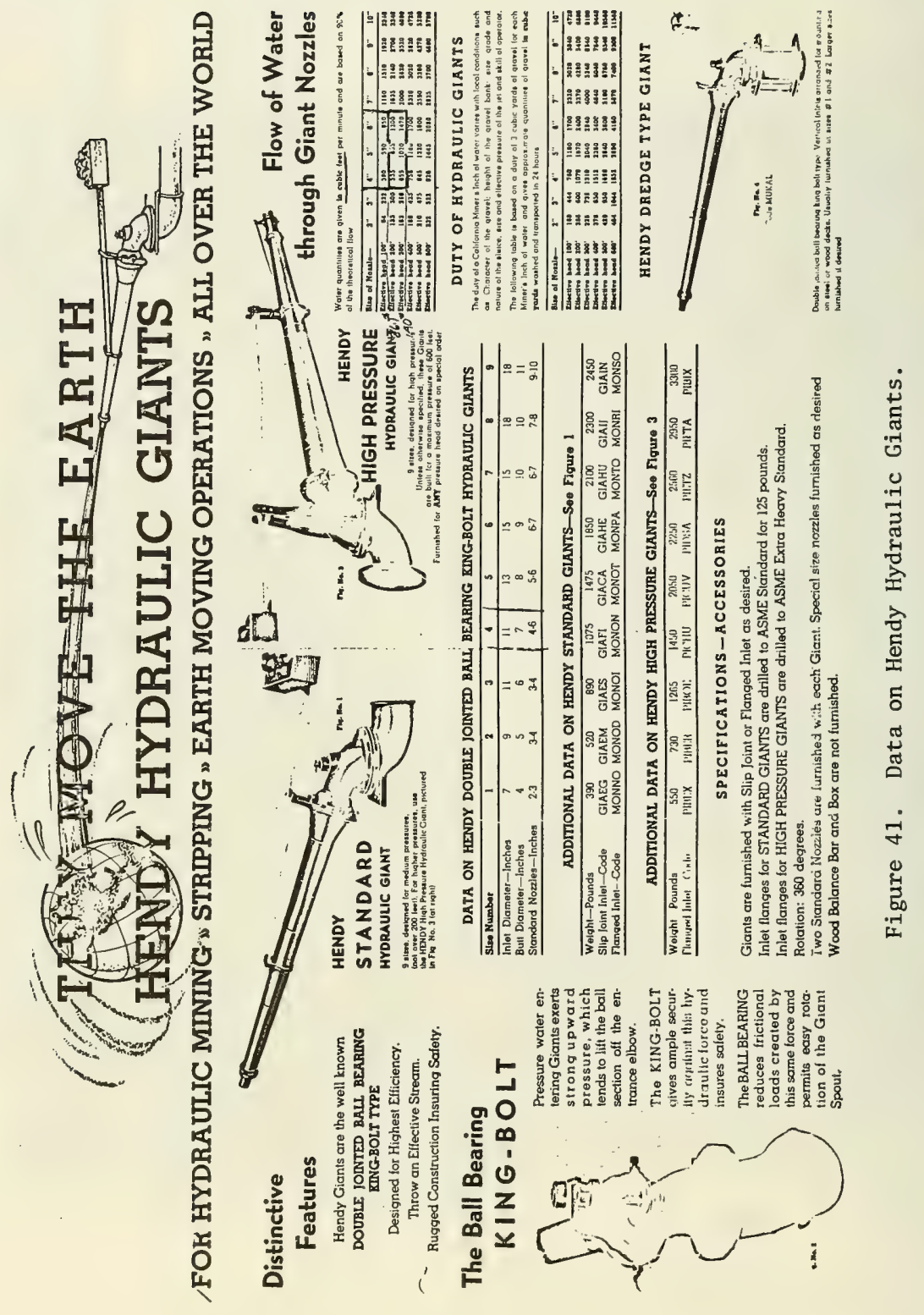




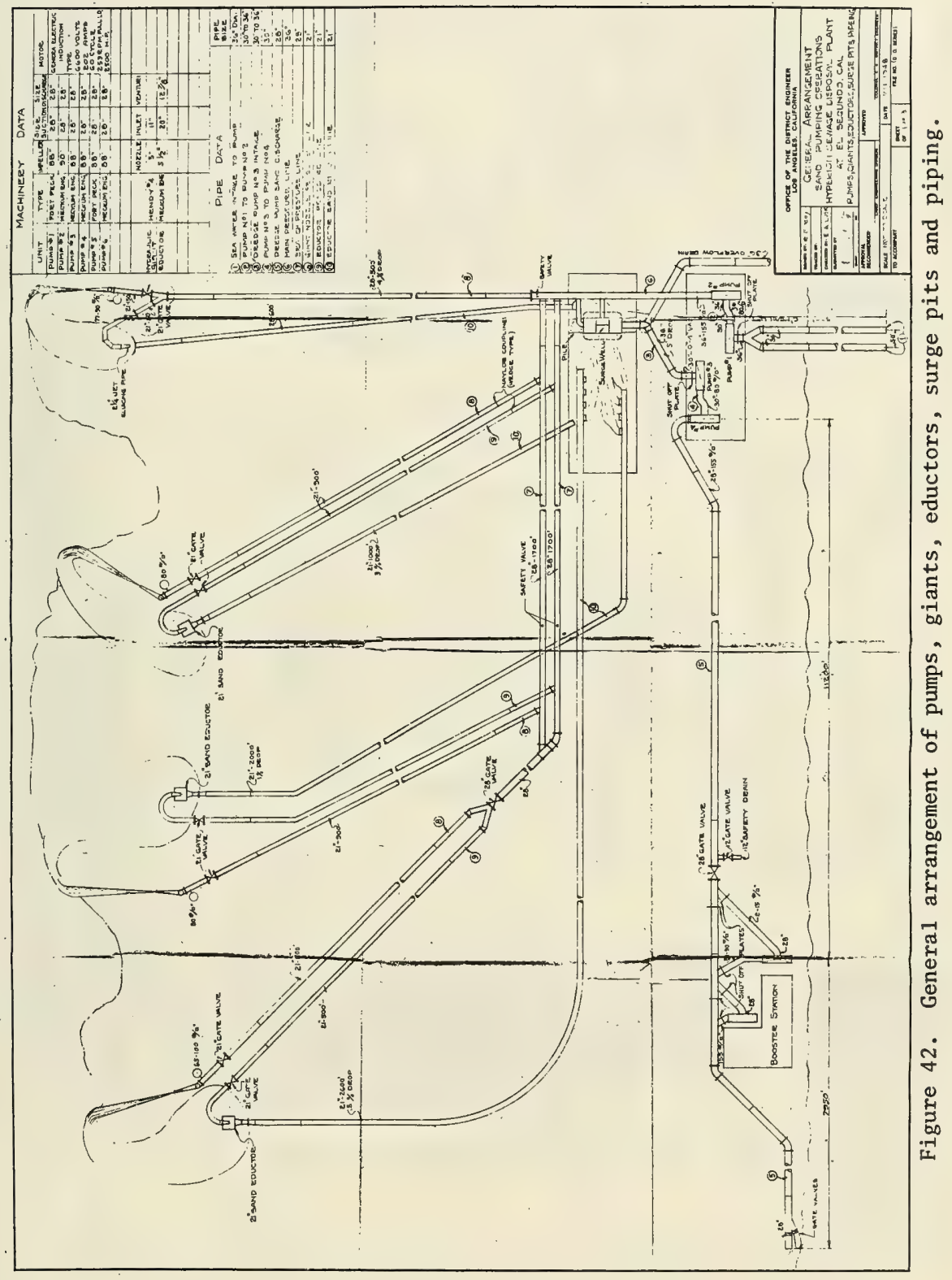




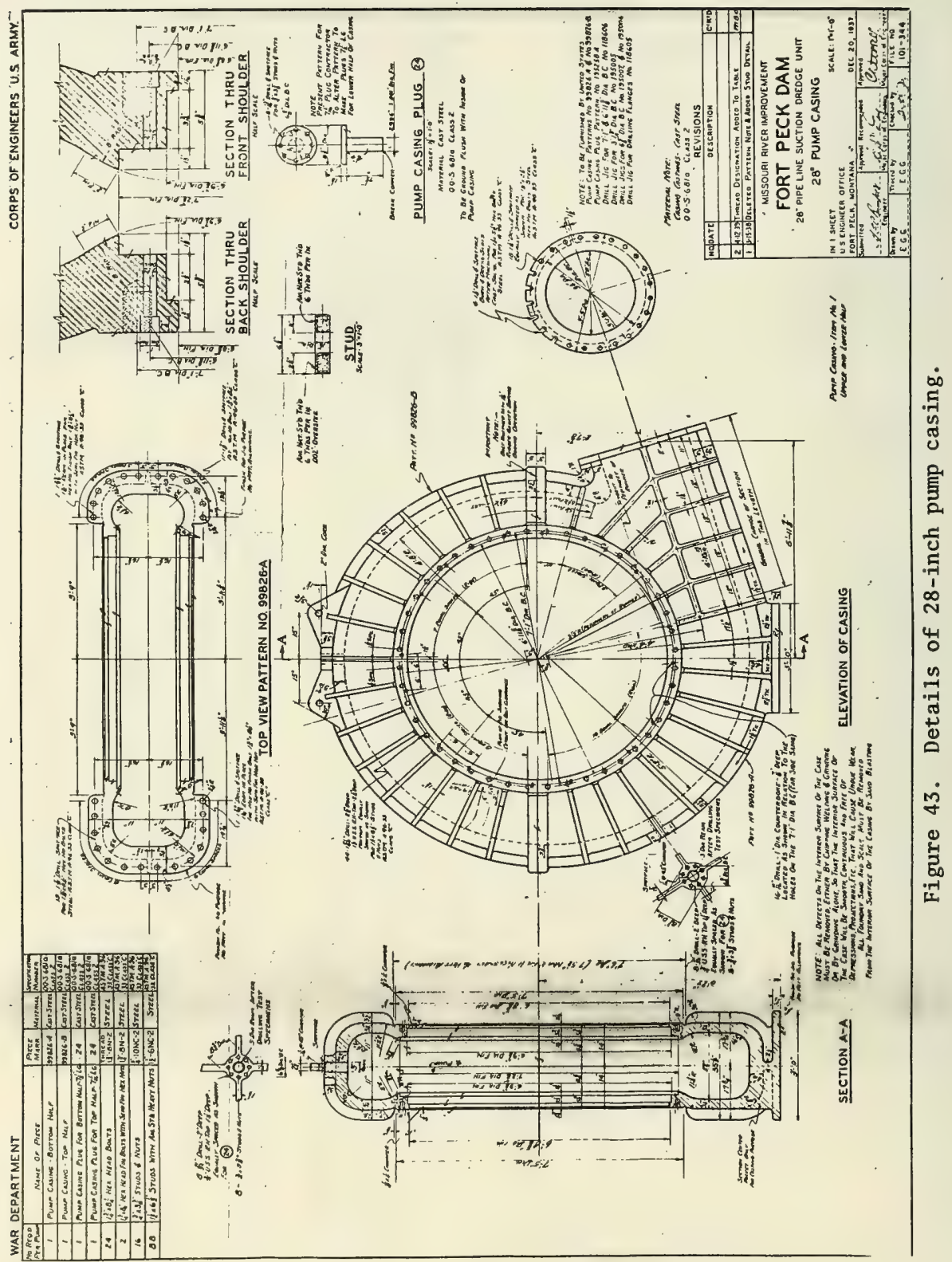




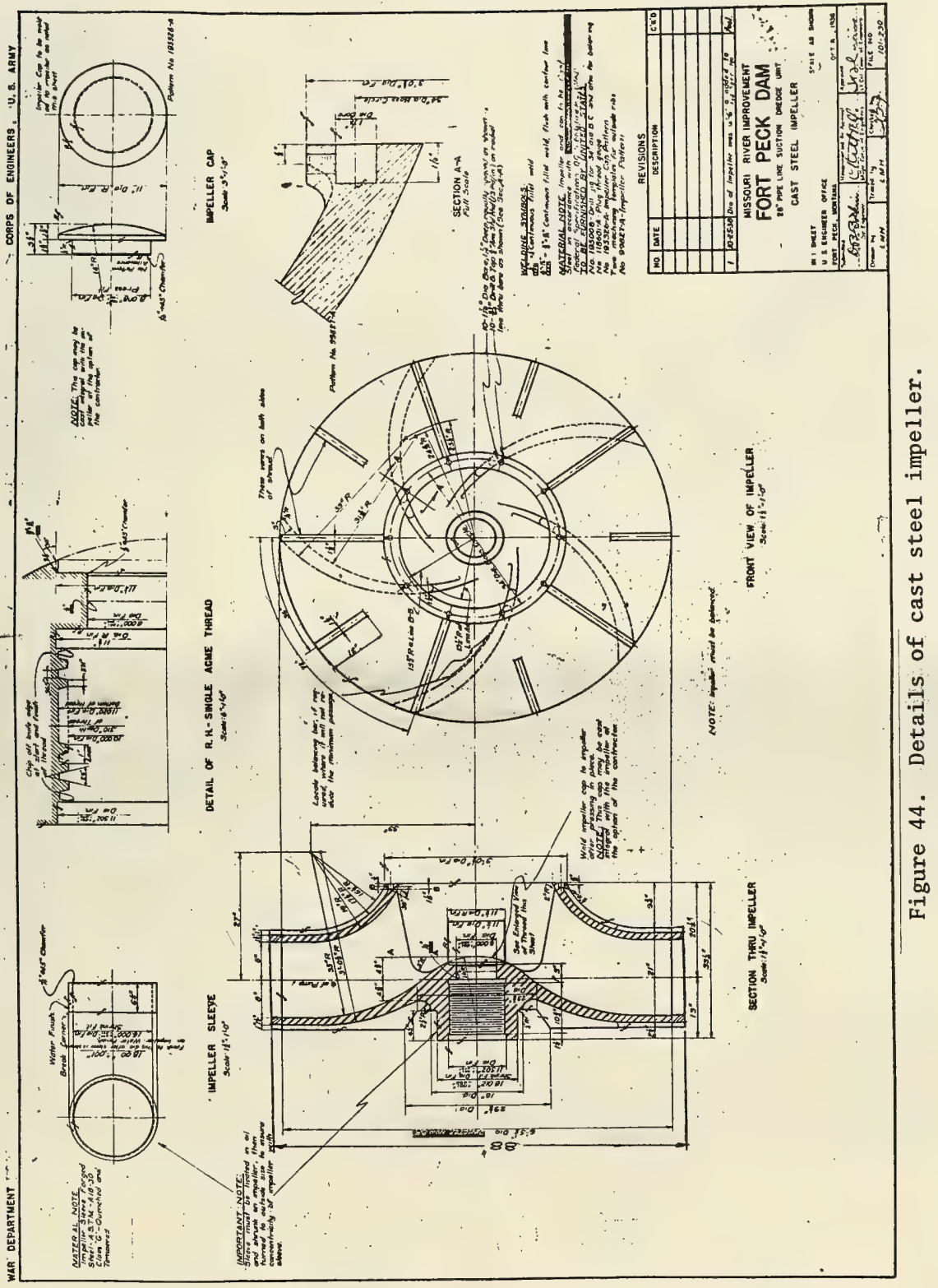




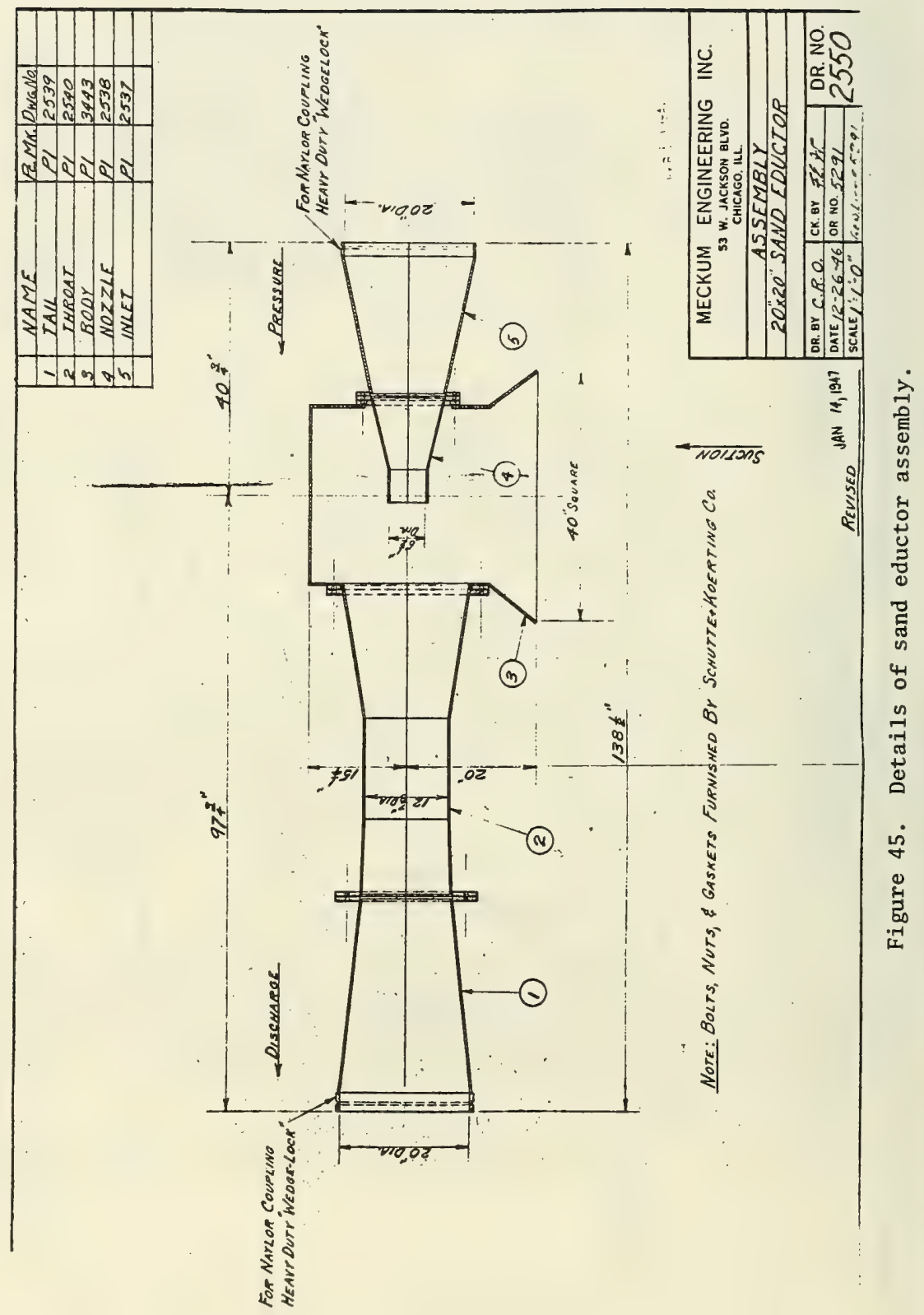




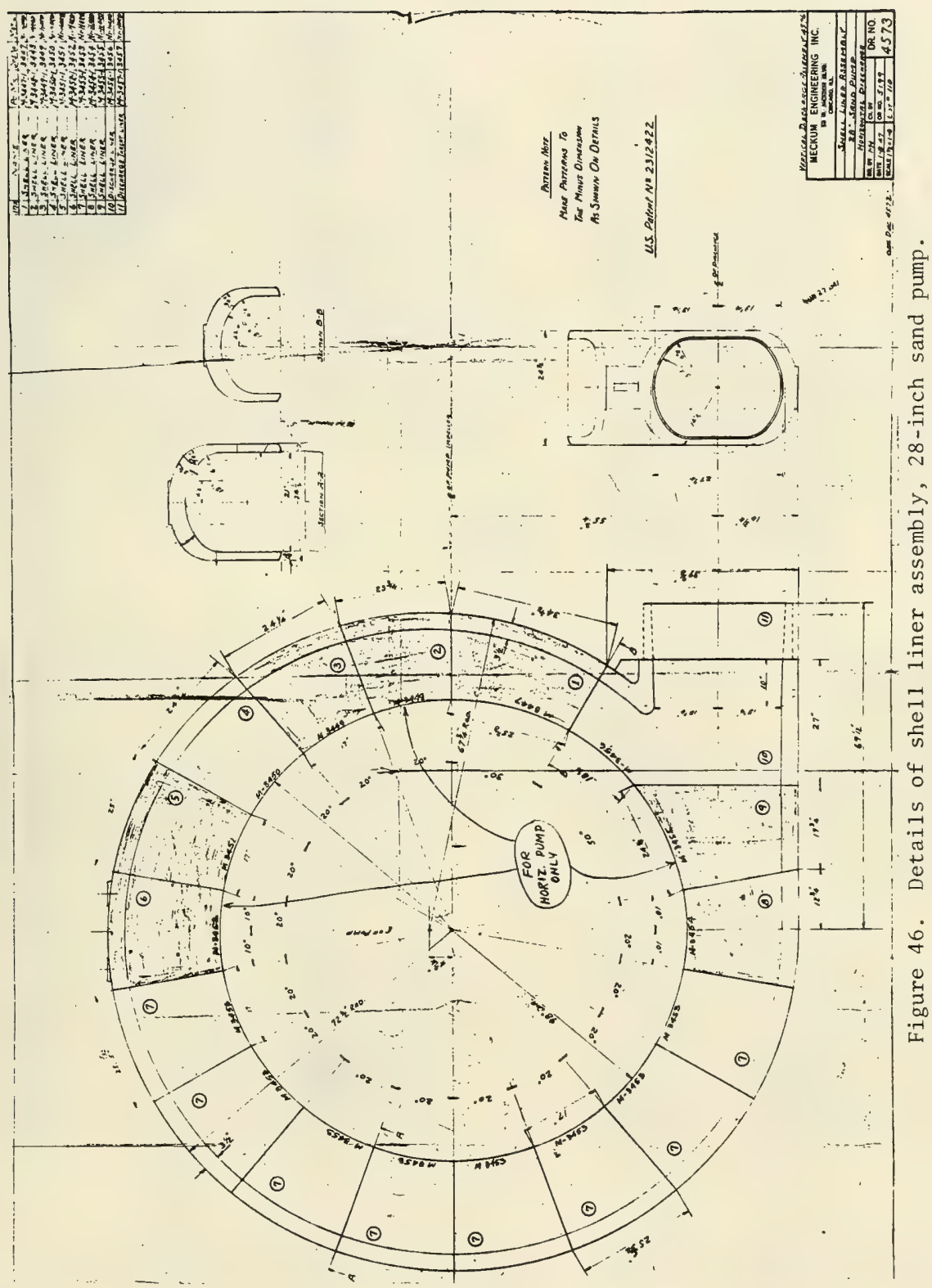




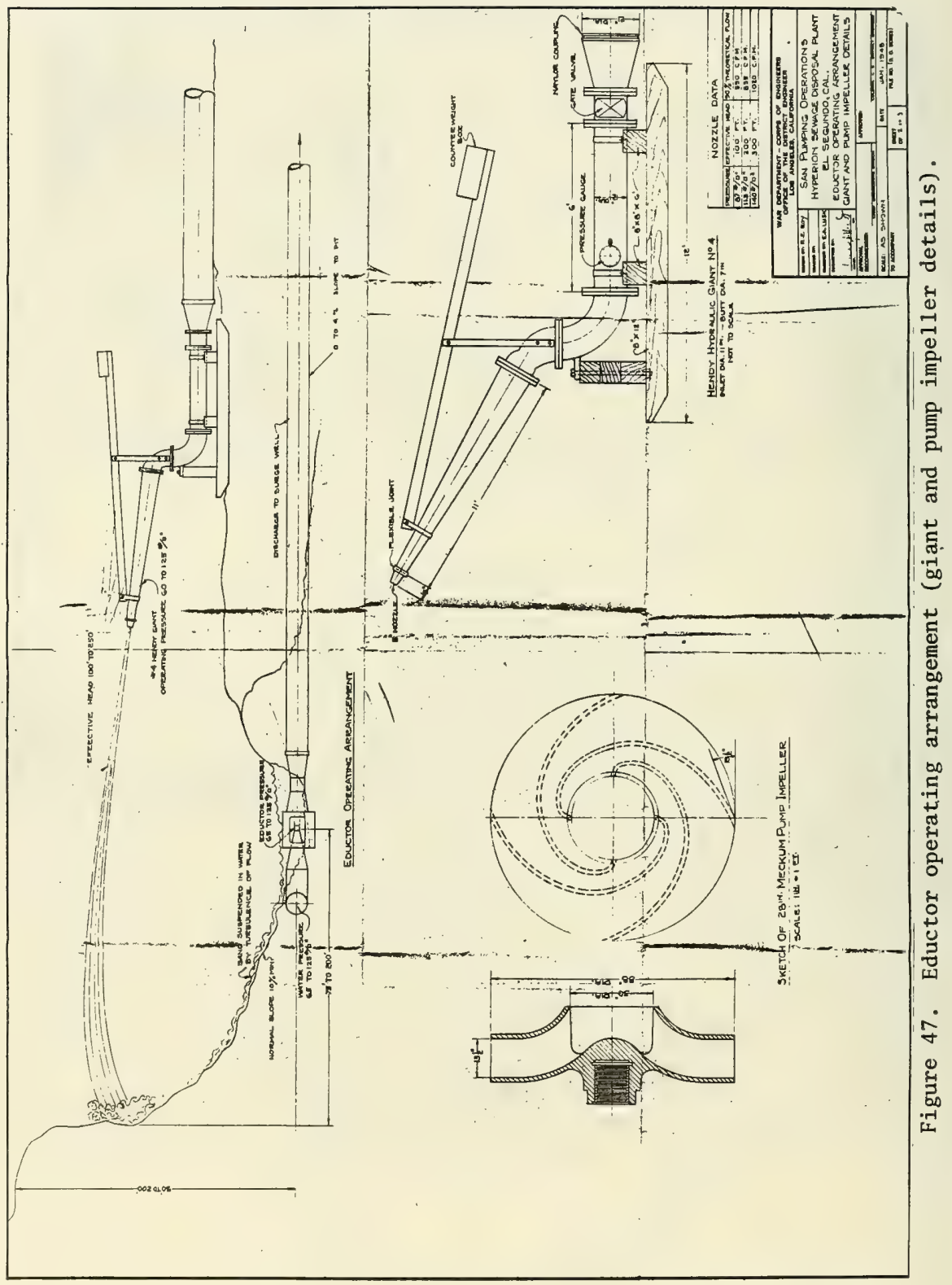




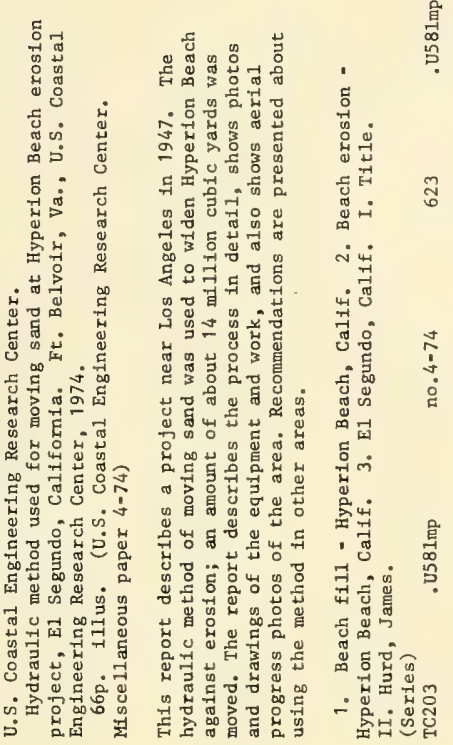

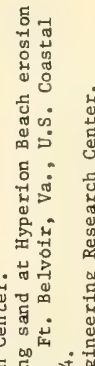

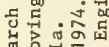

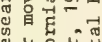

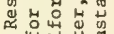

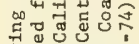

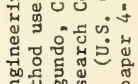

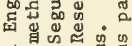
तौ 0 - 10 光

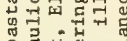

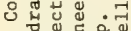

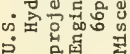

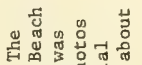

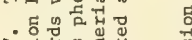

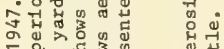

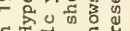

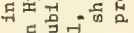

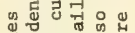

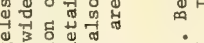

काषं

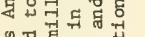

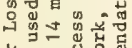

为

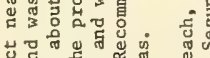

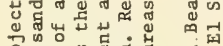

$\Gamma$ क क प

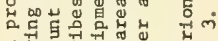

๗

कू के की ब्ड ०

究岁称造出出

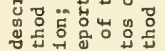

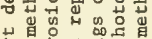

แ

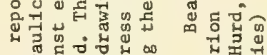

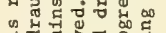

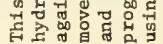

5.

ขี

รู

ต

5:

iो

है

茫

मुण

岗

工

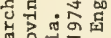

造

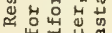

蝶击苛

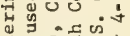

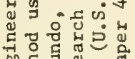

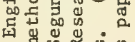

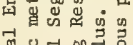

范品四

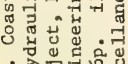

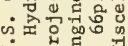

क्य造敌

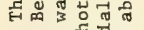

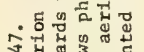

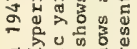

द्र谣的 है

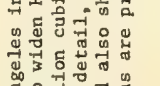

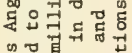

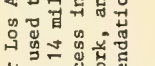

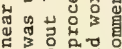

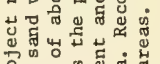

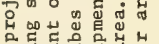

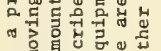

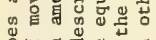

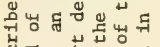

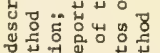

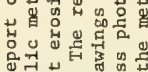

연교

5

要

我

๑ึ

กู

तi

प्त

ปูं के

落

ธू लं

䓵艺

1. तु

곤

รี

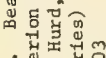

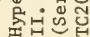

\section{苟 \\ 䒚

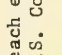 \\ 雪 \\ ธำ: \\ मू \\ 家 \\ 㟧 \\ 过萬}

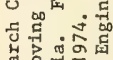

g

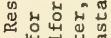

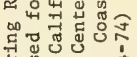

出 00 :

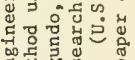

舀

नै की

出

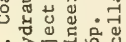

कर c

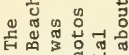

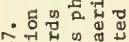

今心

武的各 क

क्र

可旸品留

तi

운극 모동

क व्य

=-

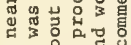

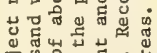

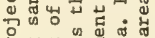

오잉

๓

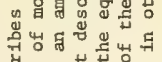

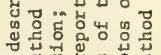

论

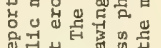

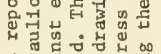

击
冒

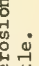

결 लु

ㄴํㄱ

4.

जु

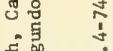

वृ क

酉

जิ

है.

- 羿 息

굴

댕 न

명

골

- 



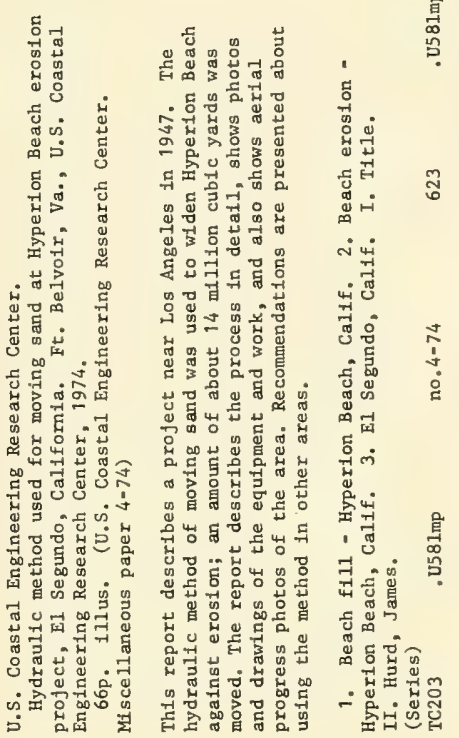

c.

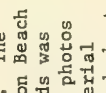

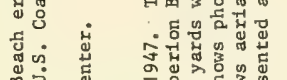

동

๑

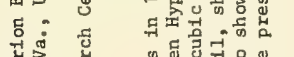

मु

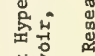

范势

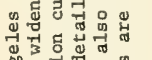

岳

क ते

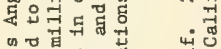

ํํำ

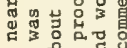

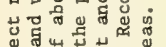

出台出

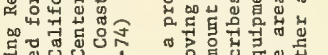

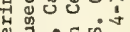

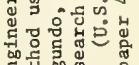

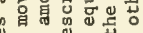

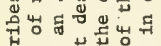

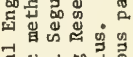

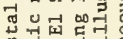

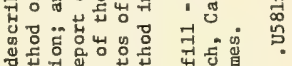

为 牙

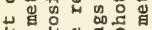

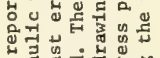

ن

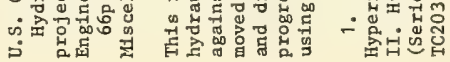

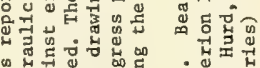

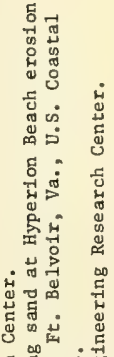

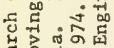

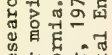

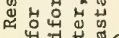

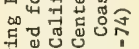

प्रें

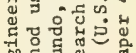

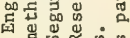

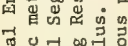

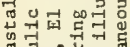

ठํ

ம
,

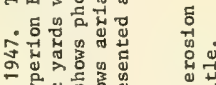

र्रेण की है

平空

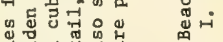

पू

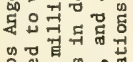

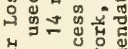

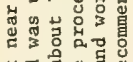

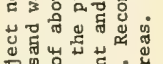

象出诺

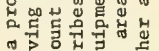

の首息岁要导范

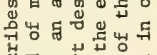

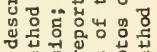

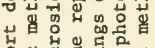

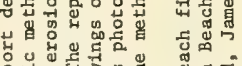

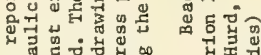

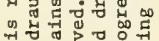

ง
龺

๓ู้

i荘

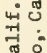

ธ็

๓)

हुำ

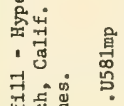

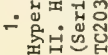

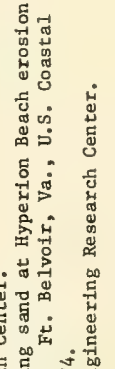

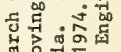

ชึ.

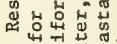

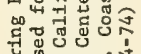

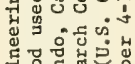

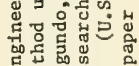

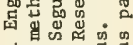

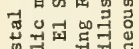

ठํ

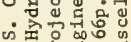

का 点舟

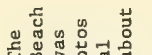

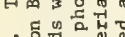

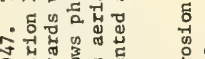

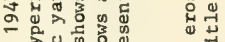

牙的的

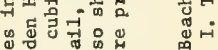

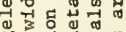

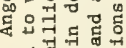

की

उา 近

ता 4

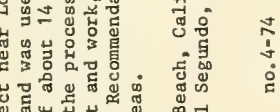

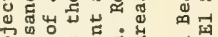

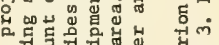

๙

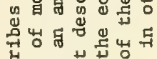

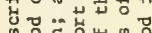

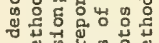

4

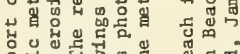

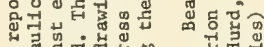

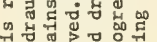

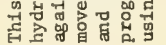

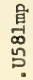

స్తి

i

फं

空幽

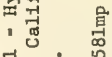

교

.

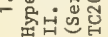





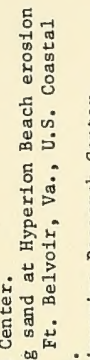

รี .

ช้

कू

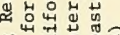

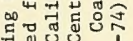

出

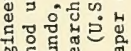

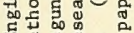

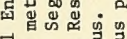

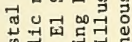

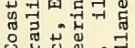

.

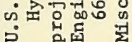

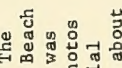

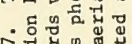

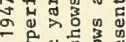

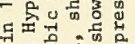

踏

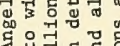

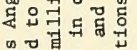

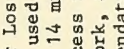

出

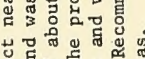

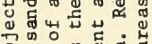

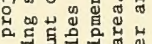

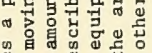

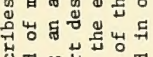

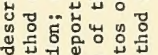

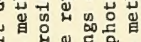

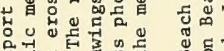

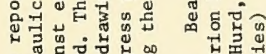

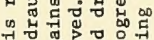

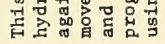

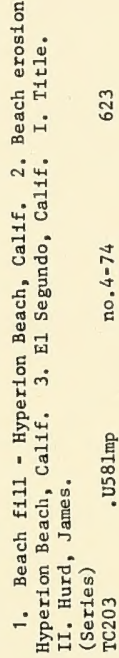

돈-1

वू.

๓

पi

窑

落

मू

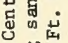

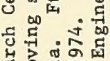

药

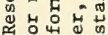

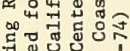

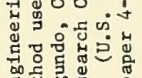

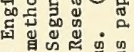

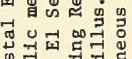

क न्ञ

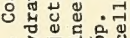

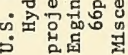

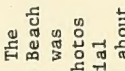

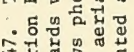

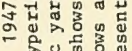

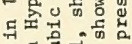

घ

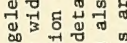

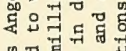

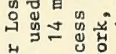

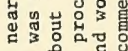

प चे

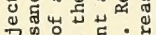

०० का तो ने

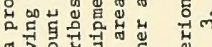

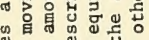

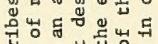

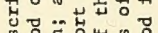

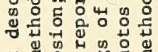

+ 㟧

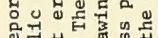

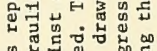

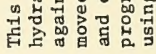

s

㟧

รี

तi

फै ชึ

ชึ: 武

में.

空出

- ฮู 亶

चี

ญ 둥

.

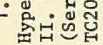

도

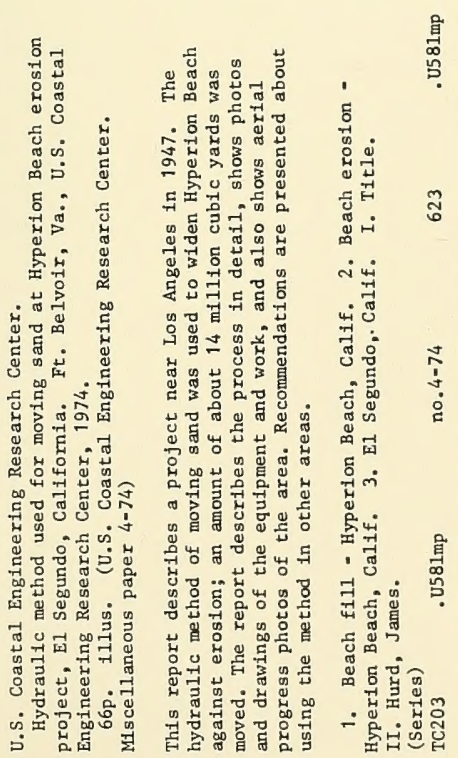

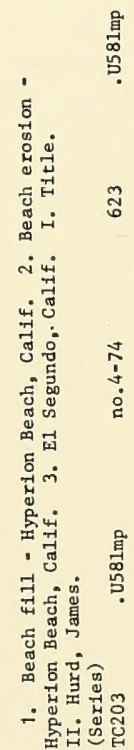

员-

क

ปู

ตั ह

ร) :

मू गु

串 कू

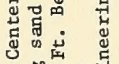

号离.

ซु

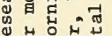

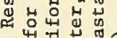

車武岂苍命

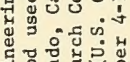

菏

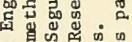

ศึ

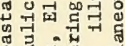

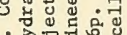

i

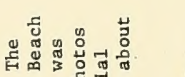

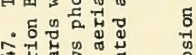

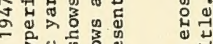

다루

\&

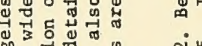

实

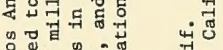

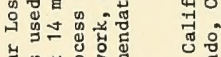

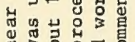

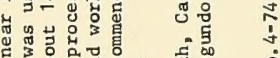

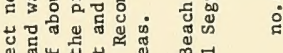

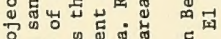

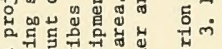

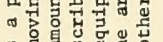

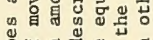

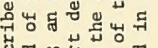

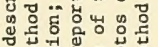

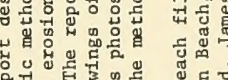

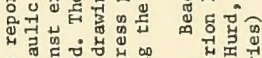

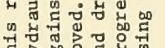

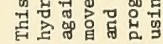

㽬

ชู

$\frac{1}{3}$

承

, 势, 貝

हैं

a

- म्山्य 궁

- 


